Louisiana State University

LSU Digital Commons

$1-1-2009$

\title{
Crustal redistribution, crust-mantle recycling and Phanerozoic evolution of the continental crust
}

\author{
Peter D. Clift \\ University of Aberdeen \\ Paola Vannucchi \\ Università degli Studi di Firenze \\ Jason Phipps Morgan \\ Cornell University
}

Follow this and additional works at: https://digitalcommons.Isu.edu/geo_pubs

\section{Recommended Citation}

Clift, P., Vannucchi, P., \& Morgan, J. (2009). Crustal redistribution, crust-mantle recycling and Phanerozoic evolution of the continental crust. Earth-Science Reviews, 97 (1-4), 80-104. https://doi.org/10.1016/ j.earscirev.2009.10.003

This Article is brought to you for free and open access by the Department of Geology and Geophysics at LSU Digital Commons. It has been accepted for inclusion in Faculty Publications by an authorized administrator of LSU Digital Commons. For more information, please contact ir@lsu.edu. 


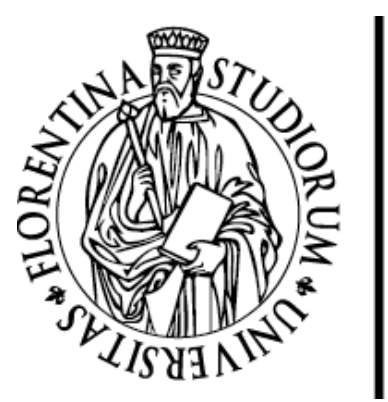

\section{UNIVERSITÀ \\ DEGLI STUDI \\ FIRENZE}

FLORE

Repository istituzionale dell'Università degli Studi di Firenze

\section{Crustal redistribution, crust-mantle recycling and Phanerozoic evolution of the continental crust}

Questa è la Versione finale referata (Post print/Accepted manuscript) della seguente pubblicazione:

Original Citation:

Crustal redistribution, crust-mantle recycling and Phanerozoic evolution of the continental crust / P.Clift; P.Vannucchi; J.

PhippsMorgan. - In: EARTH-SCIENCE REVIEWS. - ISSN 0012-8252. - STAMPA. - 97(2009), pp. 80-104.

[10.1016/j.earscirev.2009.10.003]

Availability:

This version is available at: $2158 / 375652$ since: $2019-07-17 T 10: 55: 17 Z$

Published version:

DOI: $10.1016 /$ j.earscirev.2009.10.003

Terms of use:

Open Access

La pubblicazione è resa disponibile sotto le norme e i termini della licenza di deposito, secondo quanto stabilito dalla

Policy per l'accesso aperto dell'Università degli Studi di Firenze (https://www.sba.unifi.it/upload/policy-oa-2016-1.pdf)

Publisher copyright claim: 


\title{
Crustal redistribution, crust-mantle recycling and Phanerozoic evolution of the continental crust
}

\author{
Peter D. Clift ${ }^{\mathrm{a}, *}$, Paola Vannucchi ${ }^{\mathrm{b}}$, Jason Phipps Morgan ${ }^{\mathrm{c}}$ \\ a School of Geosciences, Meston Building, University of Aberdeen, Aberdeen, AB24 3UE, United Kingdom \\ b Dipartimento di Scienze della Terra, Università degli Studi di Firenze, Via La Pira, 4, 50121 Firenze, Italy \\ c Department of Earth and Atmospheric Sciences, 3140 Snee Hall, Cornell University, Ithaca, NY 14853, USA
}

\section{A R T I C L E I N F O}

\section{Article history:}

Received 25 February 2009

Accepted 1 October 2009

Available online 14 October 2009

\section{Keywords:}

subduction

delamination

erosion

recycling

\begin{abstract}
A B S T R A C T
We here attempt a global scale mass balance of the continental crust during the Phanerozoic and especially the Cenozoic (65 Ma). Continental crust is mostly recycled back into the mantle as a result of the subduction of sediment in trenches $\left(1.65 \mathrm{~km}^{3} / \mathrm{a}\right)$, by the subduction of eroded forearc basement $\left(1.3 \mathrm{~km}^{3} / \mathrm{a}\right)$ and by the delamination of lower crustal material from orogenic plateaus (ca. $1.1 \mathrm{~km}^{3} / \mathrm{a}$ ). Subduction of rifted crust in continent-continent collision zones $\left(0.4 \mathrm{~km}^{3} / \mathrm{a}\right)$, and dissolved materials fixed into the oceanic crust (ca. $0.4 \mathrm{~km}^{3} / \mathrm{a}$ ) are less important crustal sinks. At these rates the entire continental crust could be reworked in around $1.8 \mathrm{Ga}$. Nd isotope data indicate that ca. $80 \%$ of the subducted continental crust is not recycled by melting at shallow levels back into arcs, but is subducted to depth into the upper mantle. Continentcontinent collision zones do not generally form new crust, but rather cause crustal loss by subduction and as a result of their physical erosion, which exports crust from the orogen to ocean basins where it may be subducted. Regional sedimentation rates suggest that most orogens have their topography eliminated within 100-200 million years. We estimate that during the Cenozoic the global rivers exported an average of $1.8 \mathrm{~km}^{3} / \mathrm{a}$ to the oceans, approximately balancing the subducted loss. Accretion of sediment to active continental margins is a small contribution to crustal construction (ca. $0.3 \mathrm{~km}^{3} / \mathrm{a}$ ). Similarly, continental large igneous provinces (flood basalts) represent construction of only around $0.12 \mathrm{~km}^{3} / \mathrm{a}$, even after accounting for their intrusive roots. If oceanic plateaus are accreted to continental margins then they would average construction rates of $1.1 \mathrm{~km}^{3} / \mathrm{a}$, meaning that to keep constant crustal volumes, arc magmatism would have to maintain production of around $3.8 \mathrm{~km}^{3} / \mathrm{a}$ (or $94 \mathrm{~km}^{3} / \mathrm{Ma} / \mathrm{km}$ of trench). This slightly exceeds the rates derived from sparse seismic experiments in oceanic arc systems. Although the crust appears to be in a state of rough equilibrium during the Phanerozoic, 200-300 million years cycles in sealevel may be governed in part by periods of crustal growth and destruction. During the Cenozoic the crustal volume may be running a long term loss of $<1.8 \mathrm{~km}^{3} /$ a, meaning that arc production rates could be as low at $2.0 \mathrm{~km}^{3} / \mathrm{a}$ $\left(50 \mathrm{~km}^{3} / \mathrm{Ma} / \mathrm{km}\right)$, if sealevel fall approaches $175 \mathrm{~m}$ since $65 \mathrm{Ma}$. Periods of orogeny cause crustal thickening and enhanced loss via subduction and delamination, effectively increasing the size of the ocean basins and thus freeboard.
\end{abstract}

(c) 2009 Elsevier B.V. All rights reserved.

\section{Contents}

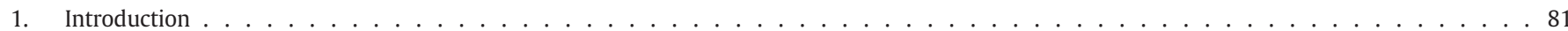

2. Loss of crust during "steady state" subduction . . . . . . . . . . . . . . . . . . . . . . . . . . . . . . . . . 82

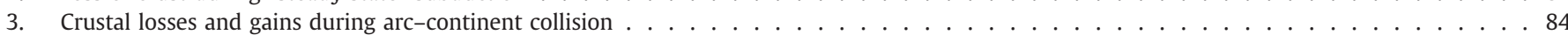

4. The composition of the continental crust . . . . . . . . . . . . . . . . . . . . . . . . . . . . . 86

5. Crustal losses during continent-continent collision . . . . . . . . . . . . . . . . . . . . . . . . . . . . . . . . 87

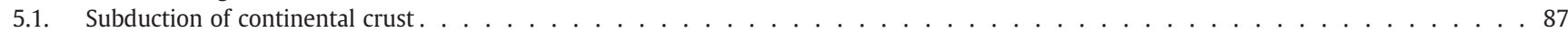

5.2. Erosional destruction of orogenic crust . . . . . . . . . . . . . . . . . . . . . . . . . . . 88

5.3. Erosional destruction of cratonic crust during the Cenozoic. . . . . . . . . . . . . . . . . . . . . . . . . . . . . . . . . . . . . . . . . . 90

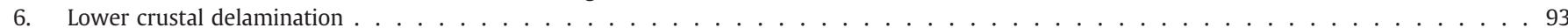

\footnotetext{
* Corresponding author.

E-mail address: pclift@abdn.ac.uk (P.D. Clift).
} 
7. Large igneous provinces . . . . . . . . . . . . . . . . . . . . . . . . . . . . . . . . . . . . . . . . 95

7.1. Oceanic LIPs. . . . . . . . . . . . . . . . . . . . . . . . . . . . . . . . . . . . . . . . . . . . . . . . . . . . 95

7.2. Continental flood basalts. . . . . . . . . . . . . . . . . . . . . . . . . . . . . . . . . . . . . . . . 95

8. Arc magmatism . . . . . . . . . . . . . . . . . . . . . . . . . . . . . . . . . . . 97

9. Discussion and conclusions . . . . . . . . . . . . . . . . . . . . . . . . . . . . . . . . . . . . . . . . . 98

Acknowledgements . . . . . . . . . . . . . . . . . . . . . . . . . . . . . . . . . . . . . . . 99

References.......................................................99

\section{Introduction}

Quantifying the processes that have formed and then maintained the continental crust remains one of the most controversial aspects of modern Earth sciences. Although it is clear that the continental crust was formed as a result of differentiation from the mantle there continues to be debate as to how this was generated and exactly when the bulk of the crust was formed. In some models the volume of continental crust has remained essentially unchanged since the earliest Archean (Fyfe, 1978; Armstrong and Harmon, 1981; Phipps Morgan and Morgan, 1999), while others have argued that the volume of crust has grown through time (Hurley and Rand, 1969; Moorbath, 1978; O'Nions et al., 1979; Albarède and Brouxel, 1987; Kramers and Tolstikhin, 1997). Dating studies of zircons from continental cratons now argue for much of the crust being generated in a series of pulses timed at approximately 1.2, 1.9, 2.7 and 3.3 Ga (Gastil, 1960; Hurley and Rand, 1969; Kemp et al., 2006), a fact consistent with ${ }^{187} \mathrm{Re} /{ }^{187} \mathrm{Os}$ isotope data that imply mantle depletion events at $1.2,1.9,2.7 \mathrm{Ga}$ (Parman, 2007; Pearson et al., 2007). Although growth may be episodic we recognize that peaks in zircon ages may instead reflect preferential preservation, perhaps linked to the development of super continents, rather than periods of enhanced crust generation. The processes that generated the crust in the deep geological past also remain controversial because the age of the onset of plate tectonics has been debated as being as young as $1 \mathrm{Ga}$ to > 4 Ga (Stern, 2005; Cawood et al., 2006; Witze, 2006).

In this paper we examine the processes operational during the Phanerozoic ( $<540 \mathrm{Ma}$ ), and particularly during the Cenozoic, that have been responsible for the destruction of existing crust and the generation of new crust. We do this because during this time period it is practical to quantify the flux of material in and out of the mantle and to assess how closely this balance has been maintained. This allows us to isolate those processes that are most important in crustal generation. This does not mean that these were necessarily the dominant crustal construction and destruction processes in the Precambrian, but it does allow us to understand the rates of crustal recycling on the modern planet. For the purpose of this paper we define crustal reworking as being a process affecting material within the crust, and recycling as referring to material that passes back into the mantle.

Continental crust is mostly recycled back to the mantle via subduction zones, but is potentially generated by a number of processes including subduction-related magmatism and the emplacement of large igneous provinces (LIPs). In this paper we quantify each of these processes to determine which are dominant. We often use an implicit assumption that at the first order level net losses and gains in Phanerozoic crustal volumes have been small, as suggested by freeboard arguments. Schubert and Reymer (1985) argued that because of the generally constant degree of continental freeboard above mean sealevel during the Phanerozoic

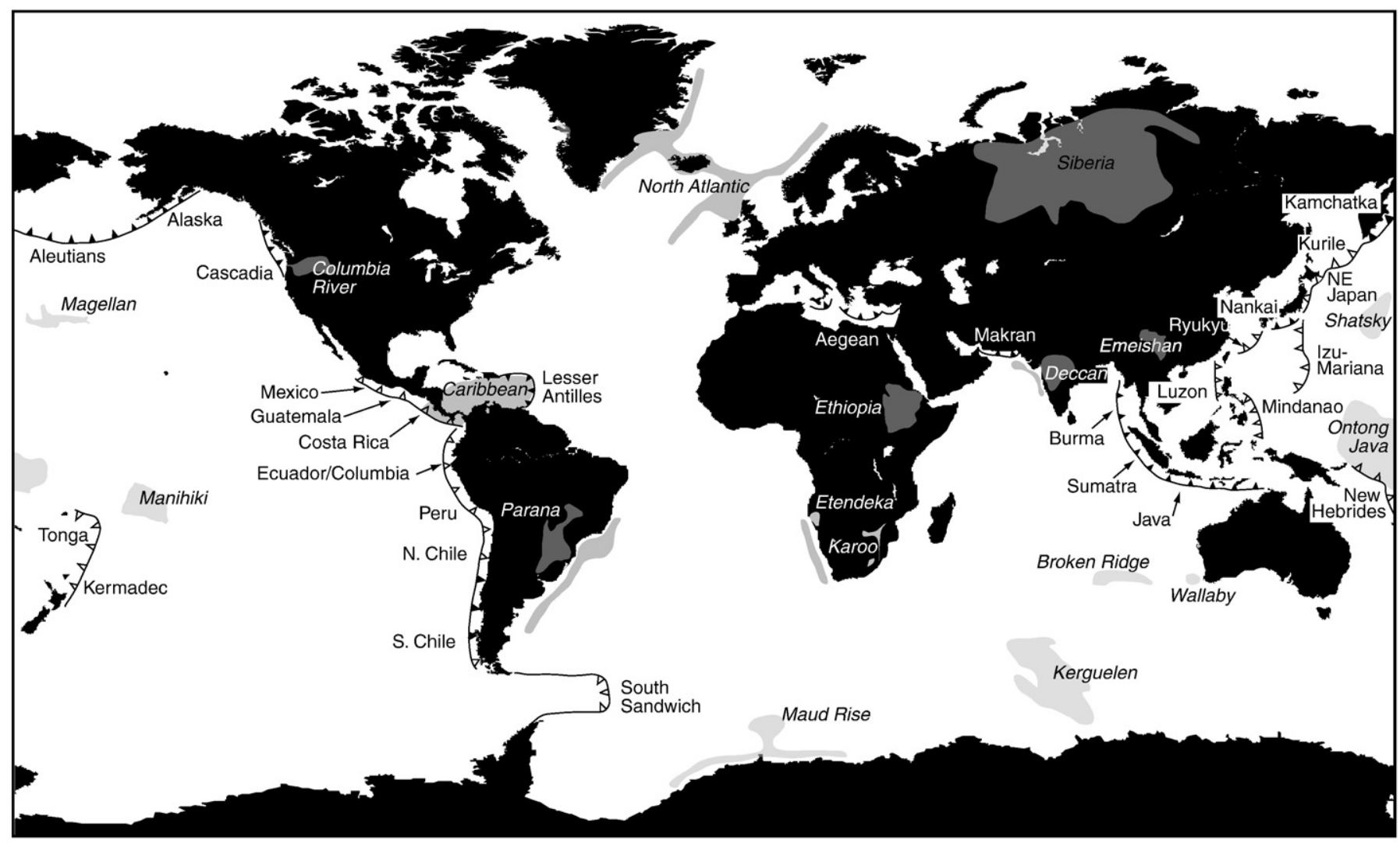

Fig. 1. Map of the Earth showing the location of the major subduction zones and large igneous provinces (names in italics) mentioned in this paper. 
Table 1

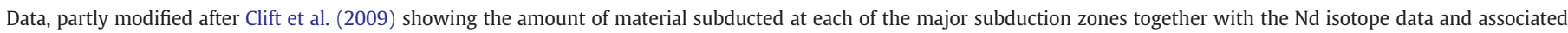
references that allow a simple calculation of continental recycling rates to be determined.

\begin{tabular}{|c|c|c|c|c|c|c|c|c|c|c|}
\hline Name & $\begin{array}{l}\text { Length } \\
(\mathrm{km})\end{array}$ & $\begin{array}{l}\text { Convergence } \\
\text { rate } \\
(\mathrm{km} / \mathrm{my})\end{array}$ & $\begin{array}{l}\text { Rate of } \\
\text { sediment } \\
\text { delivery } \\
\left(\mathrm{km}^{2} / \mathrm{my} / \mathrm{km}\right)\end{array}$ & $\begin{array}{l}\text { Amount of } \\
\text { sediment } \\
\text { delivered } \\
\left(\mathrm{km}^{3} / \mathrm{my}\right)\end{array}$ & $\begin{array}{l}\text { Amount of } \\
\text { sediment } \\
\text { subducted } \\
\left(\mathrm{km}^{3} / \mathrm{m} . \mathrm{y} .\right)\end{array}$ & $\begin{array}{l}\text { Amount } \\
\text { of forearc } \\
\text { eroded } \\
\left(\mathrm{km}^{3} / \mathrm{my}\right)\end{array}$ & $\begin{array}{l}\text { Total } \\
\text { subducted } \\
\left(\mathrm{km}^{3} / \mathrm{my}\right)\end{array}$ & $\begin{array}{l}\text { Percentage } \\
\text { of sediment } \\
\text { in total } \\
\text { subducted }\end{array}$ & $\begin{array}{l}\text { Magmatic } \\
\text { productivity } \\
\left(\mathrm{km}^{3} / \mathrm{my} / \mathrm{km}\right)\end{array}$ & $\begin{array}{l}\text { Average } \\
\text { volcanic } \\
\text { epsilon } \\
\text { Nd }\end{array}$ \\
\hline North Chile & 2000 & 90 & 13 & 26,590 & 26,590 & 30,000 & 56,590 & 47 & 125 & -3.0 \\
\hline Peru & 2200 & 82 & 29 & 64,079 & 64,079 & 33,000 & 97,079 & 66 & 109 & -3.2 \\
\hline Ecuador-Colombia & 1100 & 70 & 20 & 22,192 & 22,192 & 16,500 & 38,692 & 57 & 90 & 2.0 \\
\hline Costa Rica & 450 & 80 & 17 & 7,488 & 7,488 & 47,250 & 54,738 & 14 & 113 & 6.8 \\
\hline Nicaragua & 275 & 78 & 12 & 3,333 & 3,333 & 17,600 & 20,933 & 16 & 110 & 8.0 \\
\hline Guatemala & 500 & 75 & 12 & 5,761 & 5,761 & 17,000 & 22,761 & 25 & 104 & 7.0 \\
\hline Mexico & 1700 & 70 & 22 & 36,553 & 36,553 & 68,000 & 104,553 & 35 & 95 & 4.8 \\
\hline Kurile & 1100 & 85 & 20 & 21,796 & 21,796 & 82,500 & 104,296 & 21 & 120 & 6.1 \\
\hline Kamchatka & 1100 & 80 & 36 & 39,274 & 39,274 & 132,000 & 171,274 & 23 & 113 & 8.6 \\
\hline NE Japan & 1000 & 100 & 45 & 44,800 & 44,800 & 120,000 & 164,800 & 27 & 141 & 3.8 \\
\hline Mariana & 1600 & 90 & 19 & 29,838 & 29,838 & 32,000 & 61,838 & 48 & 127 & 7.4 \\
\hline Izu-Bonin & 1300 & 95 & 19 & 24,139 & 24,139 & 52,000 & 76,139 & 32 & 126 & 8.7 \\
\hline Ryukyu & 1000 & 70 & 14 & 14,339 & 14,339 & 90,000 & 104,339 & 14 & 97 & 1.9 \\
\hline South Luzon & 400 & 90 & 19 & 7,460 & 7,460 & 19,200 & 26,660 & 28 & 127 & 5.5 \\
\hline Philippine-Mindanao & 1000 & 95 & 13 & 13,490 & 13,490 & 96,000 & 109,490 & 12 & 57 & 7.3 \\
\hline Tonga & 1500 & 110 & 23 & 34,320 & 34,320 & 114,000 & 148,320 & 23 & 155 & 8.4 \\
\hline Kermadec & 1250 & 70 & 14 & 17,580 & 17,580 & 37,500 & 55,080 & 32 & 95 & 7.9 \\
\hline Solomons & 2750 & 110 & 17 & 45,375 & 45,375 & 261,250 & 306,625 & 15 & 155 & 8.2 \\
\hline South Sandwich & 700 & 77 & 16 & 11,211 & 11,211 & 65,800 & 77,011 & 15 & 109 & 7.8 \\
\hline South Chile & 2000 & 20 & 43 & 85,760 & 71,611 & & 71,611 & 24 & 28 & 4.2 \\
\hline Lesser Antilles & 850 & 40 & 137 & 116,280 & 100,058 & & 100,058 & & 56 & 7.4 \\
\hline Oregon-Washington & 850 & 38 & 48 & 40,573 & 32,117 & & 32,117 & & 49 & 4.9 \\
\hline British Columbia & 550 & 42 & 61 & 33,497 & 28,026 & & 28,026 & & 54 & 4.9 \\
\hline Aleutians & 1500 & 75 & 54 & 81,557 & 75,535 & & 75,535 & & 87 & 7.4 \\
\hline Alaska & 2050 & 64 & 96 & 197,260 & 161,958 & & 161,958 & & 85 & 9.0 \\
\hline Taiwan-North Luzon & 700 & 30 & 95 & 66,150 & 48,924 & & 48,924 & & 42 & -1.6 \\
\hline SW Japan-Nankai & 900 & 40 & 65 & 58,232 & 36,689 & & 36,689 & & 56 & -1.5 \\
\hline Sumatra & 1800 & 60 & 83 & 149,649 & 130,262 & & 130,262 & & 73 & 2.3 \\
\hline Java & 2100 & 77 & 54 & 112,744 & 83,789 & & 83,789 & & 107 & 1.5 \\
\hline Burma-Andaman & 1800 & 65 & 99 & 178,007 & 128,527 & & 128,527 & & 39 & 5.0 \\
\hline Makran & 1000 & 38 & 179 & 179,435 & 150,346 & & 150,346 & & 53 & -3.0 \\
\hline Aegean & 1200 & 20 & 131 & 157,440 & 130,632 & & 130,632 & & 28 & 2.0 \\
\hline Total & 40,225 & & & $1,768,761$ & $1,648,091$ & $1,331,600$ & $2,979,691$ & & & \\
\hline
\end{tabular}

(i.e., the altitude of the continents above sealevel), the continental crust must in fact be growing slowly during that time period in order to counteract the effects of planetary cooling and deepening of the ocean basins. This suggestion has been interpreted to be supported by $\mathrm{Nd}$ isotopic evidence for continental evolution (Jacobsen, 1988). Nonetheless, compared to the total mass flux involved this is a very small number and a rough balance in the total crustal volume may be assumed.

\section{Loss of crust during "steady state" subduction}

Subduction zones are places where crust may be recycled back into the upper mantle, both in the form of sediment on the subducting plate that is not efficiently accreted into a forearc tectonic wedge, but also due to subduction erosion, a process whose significance was first highlighted by von Huene and Scholl (1991). Their basic conclusion that around half the convergent margins in the world are in state of long-term retreat and mass loss has been refined by later studies but remains essentially valid (Fig. 1 ). While there has been some debate about how tectonic erosion is actually accomplished (von Huene and Ranero, 2003; von Huene et al., 2004; Vannucchi et al., 2008) there is now a consensus that this process is even more important than subduction accretion in the evolution of active plate margins.

Clift and Vannucchi (2004) produced the first volume budget for the global subduction system that attempted to quantify how much crustal material is being subducted. This study assumed that the rate of sediment supply to any given trench has been effectively in steady state since $10 \mathrm{Ma}$ or more. The long-term rate of accretion at any given accretionary margin was assessed by estimating the volume of that particular accretionary wedge and dividing by the duration of the accretion. The difference between this value and the rate of sediment supply to the trench then yields the rate of sediment subduction (Table 1). Clearly, in tectonically erosive margins where no accretionary wedge is formed, all the sediment on the incoming plate is subducted and in addition, further material is stripped from the underside of the over-riding forearc. The rate at which this occurs is hard to estimate, but is often calculated based on the rates of subsidence of forearc basins, volcanic arc retreat and on the presence of arc rocks in the trench. To complicate matters tectonic erosion rates vary temporally, accelerating to high rates during the collision of ridges and seamounts with the trench system (Dupont and Herzer, 1985; Behrmann et al., 1994; Clift and Vannucchi, 2004; Hampel et al., 2004). Clift and Vannucchi (2004) concluded that margins tend to flip to an erosive mode once convergence rates exceed ca. $80 \mathrm{~mm} / \mathrm{a}$ and when trench sediment thicknesses fall below $1 \mathrm{~km}$. Rates of trench retreat (i.e., loss from the front of the over-riding plate) are not closely linked to convergence rate above this threshold and have been documented to range up to $4.7 \mathrm{~km} / \mathrm{my}$ in the South Sandwich Islands (Vanneste and Larter, 2002). 


\begin{tabular}{|c|c|c|c|c|c|c|c|c|c|}
\hline $\begin{array}{l}\text { Average } \\
\text { volcanic } \\
\text { Nd } \\
(\mathrm{ppm})\end{array}$ & $\begin{array}{l}\text { Average } \\
\text { trench } \\
\text { sediment } \\
\text { epsilon Nd }\end{array}$ & $\begin{array}{l}\text { Trench } \\
\text { sediment } \\
\text { Nd } \\
(\mathrm{ppm})\end{array}$ & $\begin{array}{l}\text { Average } \\
\text { forearc } \\
\text { basement } \\
\text { epsilon Nd }\end{array}$ & $\begin{array}{l}\text { Forearc } \\
\text { basement } \\
\text { Nd } \\
(\mathrm{ppm})\end{array}$ & $\begin{array}{l}\text { Epsilon Nd } \\
\text { subducted } \\
\text { material }\end{array}$ & $\begin{array}{l}\mathrm{Nd}(\mathrm{ppm}) \text { in } \\
\text { subducted } \\
\text { material }\end{array}$ & $\begin{array}{l}\% \text { of } \\
\text { subducted } \\
\text { material in } \\
\text { arc magma }\end{array}$ & Sediment Isotope reference & Forearc isotope reference \\
\hline 28.0 & -11.0 & 20.0 & -15.0 & 27.0 & -13.1 & 23.7 & 27 & Plank and Langmuir (1998) & Lucassen et al. (2004) \\
\hline 28.9 & -7.0 & 17.0 & -12.9 & 20.0 & -9.0 & 18.0 & 47 & Plank and Langmuir (1998) & Allegre et al. (1996) \\
\hline 18.25 & -7.0 & 16.0 & -12.5 & 20.0 & -9.3 & 17.7 & 22 & Stancin et al. (2006) & Allegre et al. (1996) \\
\hline 21.0 & -2.2 & 12.0 & 7.3 & 6.0 & 6.0 & 6.8 & 81 & Plank and Langmuir (1998) & Sinton et al. (1997) \\
\hline 19.0 & -2.2 & 12.0 & 8.0 & 5.5 & 6.4 & 6.5 & 57 & Plank and Langmuir (1998) & Carr et al. (1990) \\
\hline 23.0 & -2.2 & 15.0 & 4.0 & 6.0 & 2.4 & 8.3 & 36 & Plank and Langmuir (1998) & Sinton et al. (1997) \\
\hline 15.0 & -6.7 & 38.0 & -12.0 & 20.0 & -10.1 & 26.3 & 8 & Stancin et al. (2006) & $\begin{array}{l}\text { (Patchett and Ruiz, 1987; } \\
\text { Cameron and Cameron, 1985; } \\
\text { Smith et al., 1996) }\end{array}$ \\
\hline 12.5 & -5.9 & 20.0 & 6.1 & 12.5 & 3.6 & 14.1 & 44 & Plank and Langmuir (1998) & GEOROC \\
\hline 17.0 & -5.9 & 14.0 & -16.0 & 20.0 & -13.7 & 18.6 & 2 & Plank and Langmuir (1998) & Kepezhinskas et al. (1997) \\
\hline 22.0 & -5.9 & 22.0 & -4.0 & 27.0 & -4.5 & 25.6 & 17 & Plank and Langmuir (1998) & Iizumi et al. (2000) \\
\hline 22.0 & -4.5 & 25.0 & 7.5 & 5.7 & 1.7 & 15.0 & 18 & $\begin{array}{l}\text { (Plank and Langmuir, 1998; } \\
\text { Pearce et al., 1999) }\end{array}$ & GEOROC \\
\hline 18.0 & -2.3 & 27.0 & 6.8 & 4.4 & 3.9 & 11.6 & 14 & Plank and Langmuir (1998) & GEOROC \\
\hline 17.0 & -6.1 & 51.0 & -1.6 & 2 & -2.2 & 8.7 & 61 & $\begin{array}{l}\text { (McDermott et al., 1993; } \\
\text { Shimoda et al., 1998) }\end{array}$ & GEOROC \\
\hline 15.0 & -6.6 & 51.0 & 8.0 & 2.0 & 3.9 & 15.6 & 56 & McDermott et al. (1993) & (Castillo, 1996; Sajona et al., 2000) \\
\hline 15.0 & -5.5 & 51.0 & 1.2 & 2.0 & 0.4 & 8.0 & 25 & $\begin{array}{l}\text { (McDermott et al., 1993; } \\
\text { Shimoda et al., 1998) }\end{array}$ & (Castillo, 1996; Sajona et al., 2000) \\
\hline 9.4 & -5.9 & 158.0 & 7.8 & 6.0 & 4.6 & 41.2 & 7 & Plank and Langmuir (1998) & GEOROC \\
\hline 7.7 & -5.1 & 69.0 & 7.8 & 6.0 & 3.7 & 26.1 & 12 & Plank and Langmuir (1998) & GEOROC \\
\hline 13.7 & 3.3 & 15.3 & 7.0 & 13.7 & 6.5 & 13.9 & 34 & Schuth et al. (2004) & Schuth et al. (2004) \\
\hline \multirow[t]{2}{*}{12.1} & -4.1 & 10.0 & 7.8 & 12.1 & 6.1 & 11.8 & 43 & Plank and Langmuir (1998) & \\
\hline & -9.2 & 25.0 & & & -9.2 & 25.0 & 11 & Augustsson and Bahlburg (2003) & \\
\hline 21.0 & -12.3 & 41.0 & & & -12.3 & 41.0 & 2 & $\begin{array}{l}\text { (Plank and Langmuir, 1998; } \\
\text { Parra et al., 1997) }\end{array}$ & \\
\hline 19.0 & -2.2 & 22.0 & & & -2.2 & 22.0 & 19 & Plank and Langmuir (1998) & \\
\hline 21.0 & -2.2 & 22.0 & & & -2.2 & 22.0 & 19 & Plank and Langmuir (1998) & \\
\hline 14.0 & -0.6 & 19.0 & & & -0.6 & 19.0 & 11 & Plank and Langmuir (1998) & \\
\hline 19.0 & 0.6 & 18.0 & & & 0.6 & 18.0 & 4 & Plank and Langmuir (1998) & \\
\hline 15.0 & -6.6 & 51.0 & & & -6.6 & 51.0 & 24 & McDermott et al. (1993) & \\
\hline 22.0 & -6.1 & 31.0 & & & -6.1 & 31.0 & 36 & Shimoda et al. (1998) & \\
\hline 23.0 & -14.2 & 28.0 & & & -14.2 & 28.0 & 10 & Plank and Langmuir (1998) & \\
\hline 18.0 & -9.36 & 27 & & & -9.4 & 27.0 & 17 & $\begin{array}{l}\text { (Plank and Langmuir, 1998; } \\
\text { Vroon et al., 1995) }\end{array}$ & \\
\hline 18.0 & -16.0 & 24.2 & & & -16.0 & 24.2 & 6 & Plank and Langmuir (1998) & \\
\hline 20.0 & -11.0 & 34.0 & & & -11.0 & 34.0 & 25 & Clift and Blusztajn (2005) & \\
\hline 21.0 & -7.7 & 32.0 & & & -7.7 & 32.0 & 15 & Weldeab et al. (2002) & \\
\hline
\end{tabular}

A significant revision to Clift and Vannucchi's (2004) estimate of the net average global loss rate of $90 \mathrm{~km}^{3} / \mathrm{Ma} / \mathrm{km}$ of trench was made after recognition that rates of mass loss along the central Andean margin were in fact much lower than had been inferred from the offshore data alone (Clift and Hartley, 2007). While the evidence for trench retreat is clear in two survey areas offshore the Andean margin (von Huene et al., 1997; Laursen et al., 2002) it was observed onshore that uplift of coastal terraces has been occurring, at least since the Middle Miocene, suggestive of underplating rather than the anticipated tectonic erosion under the terrestrial portion of the forearc (Ortlieb et al., 1996; Marquardt et al., 2004). This observation allowed a new rate of mass loss to be determined for the younger part of the Neogene, even though it was recognized that in the longer term the Andean margin would eventually have to revert to a faster erosion style, because the trench slope cannot steepen indefinitely. Using the Miocene-Recent slow rate for central Andean mass loss reduces the global continental mass loss rate from 90 to $74 \mathrm{~km}^{3} / \mathrm{Ma} / \mathrm{km}$ of trench (Clift and Hartley, 2007). When integrated over the entire Earth this yields an average loss rate of $3.0 \mathrm{~km}^{3} /$ a (Clift et al., 2009), which divides approximately into $1.65 \mathrm{~km}^{3} /$ a of subducted trench sediment and $1.3 \mathrm{~km}^{3} / \mathrm{a}$ of tectonically eroded forearc crust, similar to values determined independently by Scholl and von Huene (2007).

Over long periods of geologic time (i.e., $10^{7}-10^{9}$ a) the freeboard argument requires that recycled, subducted crust is replaced or implies that the surface area of the continents shrank at the same rate that the oceanic water volume increased. However, it is possible that much of the subducted material is simply recycled at relatively shallow levels by being incorporated into the magmatic output of the arc under which it is subducting. Although the sediment contribution to arc volcanism has often been quantified by geochemical and isotopic methods (Karig and Kay, 1981; Woodhead and Fraser, 1985; Plank and Langmuir, 1993; Elliott et al., 1997; Pearce et al., 1999) the number of studies that have also tried to account for the subduction of forearc crust as part of the geochemical balance is rather small (Hoernle et al., 2002; Goss and Kay, 2006).

Here we attempt to quantify the degree to which subducted crust is recycled back through the magmatic roots for the arc, rather than being subducted to depth using Nd isotopes as a tracer of continental crustal recycling. Nd is a water-immobile element that is a powerful tracer of the influence of continental crust in petrogenesis (DePaolo and Wasserburg, 1976) and is generally used to quantify the contribution of continental crust, often subducted sediments, to arc magmatism. However, we extend the approach here to account for the tectonically eroded forearc crust that is usually ignored in arc petrogenetic studies, but which is compositional distinct from the sediments and the mantle melts in terms of $\mathrm{Nd}$. This unique character compared to the arc and the mantle melts means that $\mathrm{Nd}$ can be used to estimate the contribution of eroded crust, as well as sediments to 
the arc magmas. We perform a simple mass balance using the isotope character and Nd concentrations from both the subducting sediments and forearc crust at each subduction zone, as well as the presumed composition of melts from the upper mantle in order to quantify the degree of shallow crustal recycling.

In order to do this we derive an average value for ${ }^{143} \mathrm{Nd} /{ }^{144} \mathrm{Nd}$ for the magmatic output at each arc using the published data sets of GEOROC (http://georoc.mpch-mainz.gwdg.de/georoc/) (Fig. 2). We do not attempt to filter these data for age, but add together all arc products of many ages in order to derive an average for the long-term output, because our estimates for the inputs to the trench are also based on long-term budgets spanning $>10^{7}$ a. We then use a probability density analysis to estimate the most common value for ${ }^{143} \mathrm{Nd} /{ }^{144} \mathrm{Nd}$, which we express using the $\varepsilon_{\mathrm{Nd}}$ notation (DePaolo and Wasserburg, 1976), while also noting the range of compositions, which is often wide due to the variable nature of the subduction process both spatially and temporally. In the case of oceanic arcs, where the forearc is also comprised of subduction-related magmatic rocks, the isotope composition of the forearc is also derived using the GEOROC database.

Table 1 and Fig. 2 show the results of these compilations, together with the isotopic values of the trench sediments (largely derived from the synthesis of Plank and Langmuir (1998)) and for the forearc basement. It is immediately clear that the arc magmatic rocks are systematically displaced to higher $\varepsilon_{\mathrm{Nd}}$ values compared to the trench sediments. We then calculate the $\mathrm{Nd}$ isotope compositions of the continental material being subducted by mixing the sediment and the forearc end members in the proportions determined by Clift and Vannucchi (2004), with corrected (lower) values for the Andes. The composition of melts extracted from the mantle wedge was determined from the known composition of the mantle $\left(\varepsilon_{\mathrm{Nd}} \approx 10\right)$ based on the composition of mid ocean ridge basalts (White and Hoffman, 1982) and the most primitive arc basalts. Having established the end member compositions we are able to un-mix the $\mathrm{Nd}$ composition of the magmatic output to determine the influence of subducted continental crust on petrogenesis. Our calculations have no simple way of correcting for the effects of crustal assimilation into the melts on their way to the surface in continental arcs. As result, our estimates for the degree of crustal recycling must be considered maxima.

The results of our analysis are shown in Fig. 3. At the planetary level we estimate that around three quarters of the crustal Nd passing below the marine portion of the forearcs (i.e. that material which is not recycled at shallow levels by underplating) is not recycled directly into the magmatic roots of the arc. This implies that $2.3 \mathrm{~km}^{3} / \mathrm{a}$ is being returned relatively deep into the upper mantle and possible further. Based on this data alone we cannot exclude the possibility that some of the subducted crust is underplated in the backarc region, but we have no constraints that would suggest that this is important. Naturally there is a significant degree of variability depending on the tectonic setting. Some arcs appear to show quite efficient recycling, most notably Costa Rica and Nicaragua, although it should be noted that in these cases the forearc basement comprises a slice of the Caribbean large igneous province (Hinz et al., 1996; Sinton et al., 1997), so that contributions from this source lie compositionally very close to the mantle end member, thus making accurate un-mixing difficult. However, high recycling values are also seen in the Ryukyu Arc and in Luzon, which do have good end-member separation.

Fig. 4 shows a triangular diagram that breaks down the relative contributions from trench sediment, forearc basement and mantle melts. What is striking is that many of the arc systems show a strong dominance of mantle melt, i.e. that much of the subduction magmatism is primitive (i.e. high $\varepsilon_{\mathrm{Nd}}$ values). We conclude that "steady state" subduction zones appear to be remarkably efficient venues for returning continental crust to the upper mantle, and that if continental crust is generated in these settings then it is mostly derived from melting of normal, depleted, upper mantle materials and that shallow recycling of subducted continental crust is modest. We note that numerical modeling of subduction zones has suggested that some of the subducted continental material may be stored in the shallow backarc mantle (Currie et al., 2007), a reservoir that may subsequently be tapped for remelting under certain tectonic conditions. Our budget is unable to determine whether the subducted sediments are subducted deep or stored at shallow levels in this fashion, but in either case the crustal material no longer forms part of the stable continental crust and has been recycled.

\section{Crustal losses and gains during arc-continent collision}

If ca. $2.3 \mathrm{~km}^{3}$ of continental crust is being lost back to the upper mantle each year due to "steady state" subduction processes then this must be replaced by new crust, likely mostly in the form of suprasubduction zone magmatism (Rudnick and Fountain, 1995; Taylor and McLennan, 1995; Barth et al., 2000). Although new magmas are directly added to pre-existing crust in continental arcs, new crust generated in oceanic arcs has to be accreted to existing continents before it can contribute to crustal construction. The contribution of oceanic arcs to the crustal budget is crucial. Although oceanic arcs comprise only $31 \%$ of the length of the global trench system they account for $40 \%$ of the total arc output when this is calculated based on the premise that production rates are linked to the supply of aqueous fluids (Tatsumi et al., 1983), and thus to the rates of convergence (Clift and Vannucchi, 2004). Their contribution is slightly less (37\%) when this estimate is based on the height of the melting column under the arc (Plank and Langmuir, 1988). In either case the oceanic arcs represent a major proportion of the total arc output and thus the preservation of these arcs is crucial to maintaining the mass balance of the continental crust.

If oceanic arcs are largely subducted when their ocean basins close then this would require melt production from the continental arcs to be somewhat greater to compensate for this loss. Globally the average arc production rate needed to balance the "steady state" subducted losses of $3.0 \mathrm{~km}^{3} / \mathrm{a}$ is $94 \mathrm{~km}^{3} / \mathrm{Ma} / \mathrm{km}$ (see below), yet oceanic arcs average rates of $125 \mathrm{~km}^{3} / \mathrm{Ma} / \mathrm{km}$ compared to $81 \mathrm{~km}^{3} / \mathrm{Ma} / \mathrm{km}$ for the continental arcs (Table 1 ). If the oceanic arcs are not efficiently accreted to continental margins then the continental arcs would have to generate melt at an average rate of $133 \mathrm{~km}^{3} / \mathrm{Ma} / \mathrm{km}$, which is somewhat higher than seismically-derived melting rates for even the supposed more productive oceanic arcs (Suyehiro et al., 1996; Holbrook et al., 1999; Takahashi et al., 2007). In its most basic form arc-continent collision can be envisaged as a process in which an oceanic arc collides with a passive continental margin resulting in orogeny, followed by subduction polarity reversal and establishment of an active continental margin (Fig. 5). In the process the crust of the colliding arc is transferred to the continental margin.

Estimating how much colliding oceanic crust is being accreted globally is hard because ancient accreted arcs are often deformed, dismembered and partly buried. This makes an accurate volume estimate of the original accreted crust very hard to derive. As a result we are dependent on case studies of well-defined arc accretions, where we can examine the crustal volumes and determine the efficiency of the process. However, this approach requires us to assume that the case studies are representative of the process, globally and over long periods of geologic time.

In an attempt to address whether arc accretion is an efficient process Clift et al. (2009) quantified the accretion of the oceanic Luzon Arc to the passive margin of southern China. Taiwan is generally agreed to be the type example of modern arc continent collision (Suppe, 1984; Teng, 1990; Huang et al., 2006). In this study seismic and gravity data from the Taiwan area (Carena et al., 2002; Wu et al., 2007) were used to estimate the sizes of the various tectonic blocks that comprise the island. In doing this the accretion was presumed to be a progressive process in which the North Luzon oceanic arc 


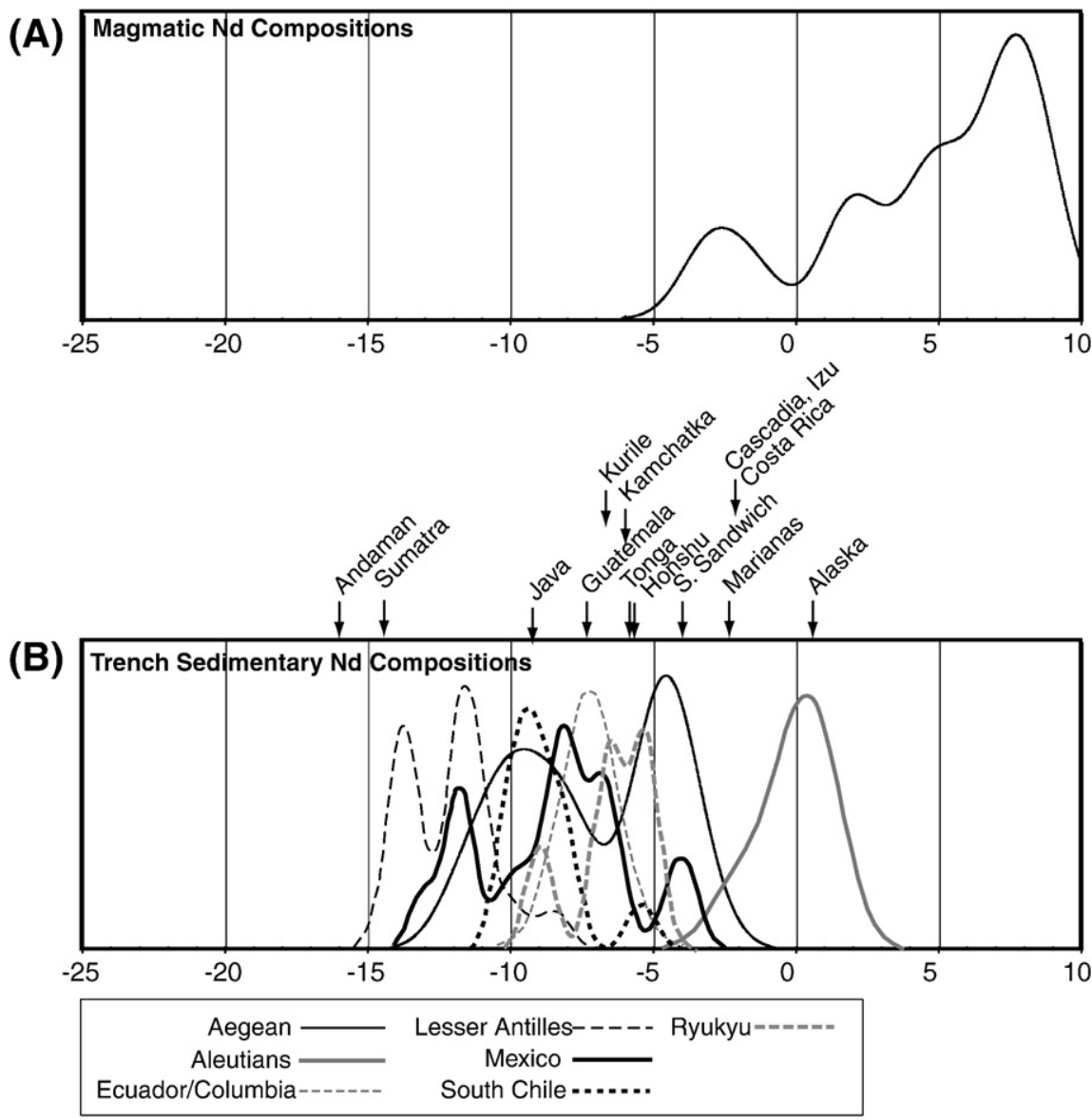

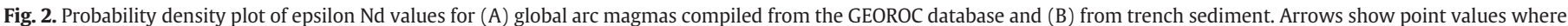

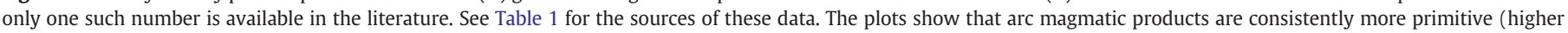

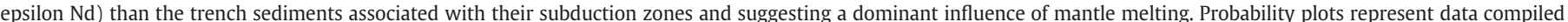

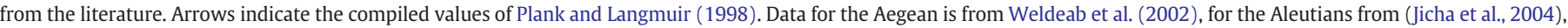

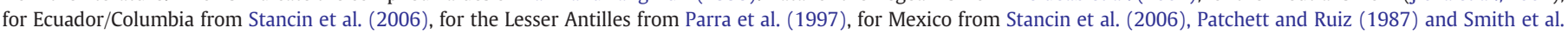
(1996), for South Chile from Augustsson and Bahlburg (2003) and for Ryukyu from Shimoda et al. (1998).

represented the pre-collisional condition, the island itself is the orogenic maximum and the Ryukyu arc would represent the new active continental margin formed in the wake of collision (Suppe,
1984; Teng et al., 2000). As shown in Fig. 6B this approximate calculation showed that ca. $90 \%$ of the mass of the Luzon Arc is transferred to the edge of continental Asia. The apparent lack of arc

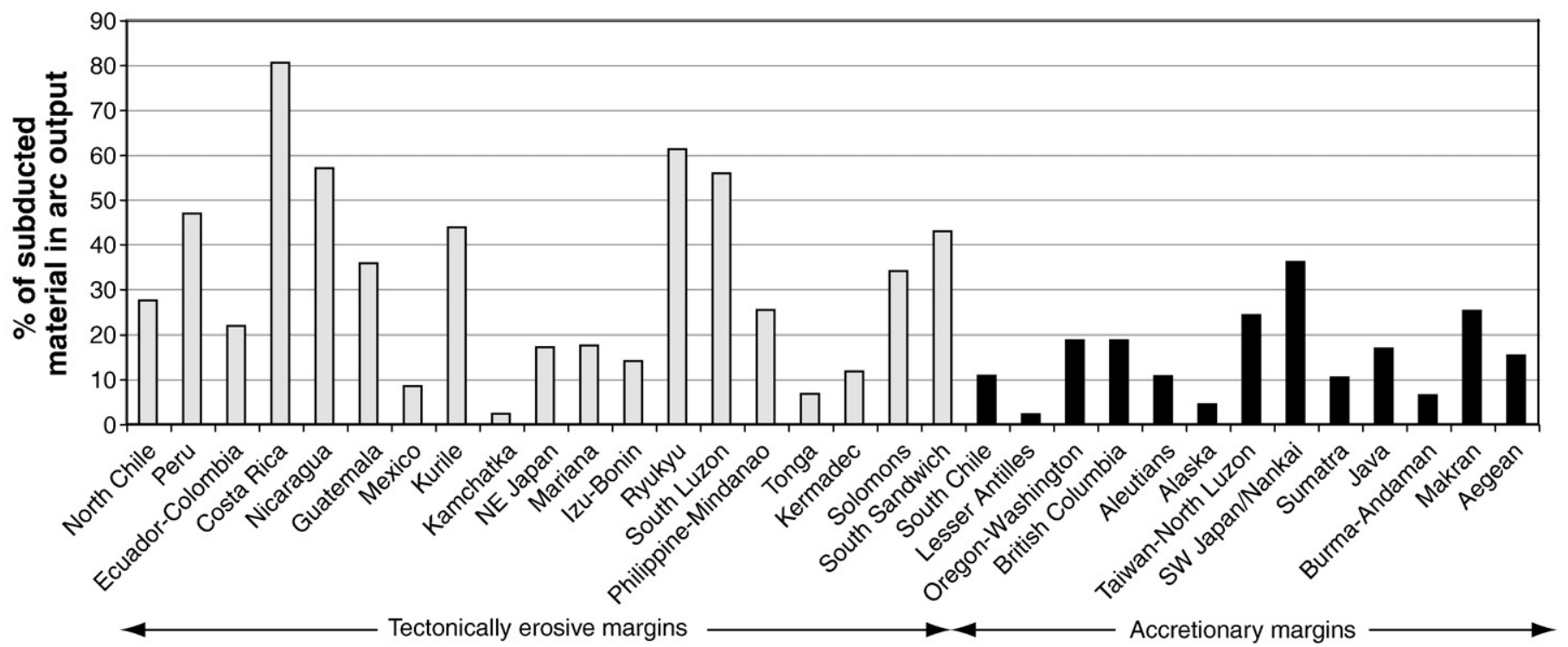

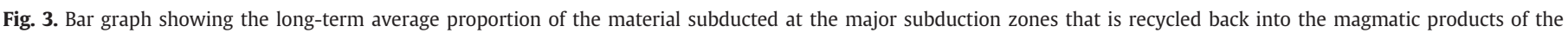
associated arc complex. 


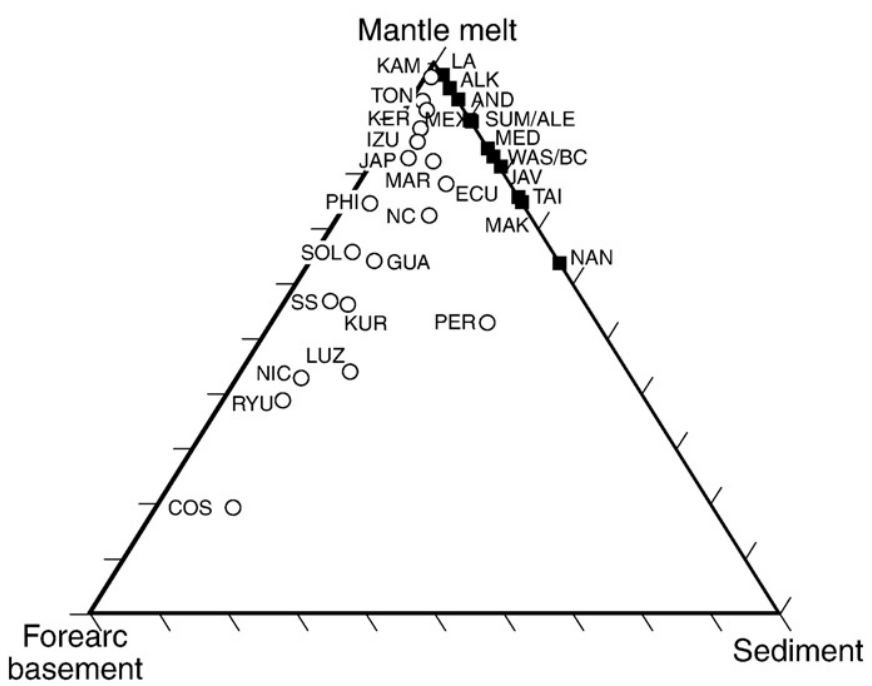

Fig. 4. Triangular diagram showing the estimated contributions from new mantle wedge melt, recycled trench sediment and eroded forearc crust to the net magmatic output of the major subduction systems. Black squares shows accretionary margins, open circle represents tectonically erosive margins. ALE = Aleutians; AND = Andaman; $\mathrm{BC}=$ British Columbia; $\mathrm{COS}=$ Costa Rica; $\mathrm{ECU}=$ Ecuador; GUA = Guatemala; JAV = Java KER = Kermadec; KUR = Kurile; LA = Lesser Antilles; LUZ = Luzon-Philippine; MAK $=$ Makran; MED = Mediterranean; $\operatorname{MEX}=$ Mexico; MIN = Mindanao; NAN = Nankai; NC = Northern Chile; NIC = Nicaragua; PER = Peru; RYU = Ryukyu; $\mathrm{SC}=$ Southern Chile; SOL = Solomons; SS = South Sandwich; SUM = Sumatra; TAI = Taiwan; TON $=$ Tonga; WAS $=$ Washington-Oregon .

rocks exposed in Taiwan itself disguises the fact that the deep roots of the island must comprise arc rocks rather than deformed Chinese passive margin sedimentary rocks. Volumes of sediments on the South China margin are quite modest (Fig. 6B) compared to the total volume of the orogen and cannot explain the mass observed under Taiwan by themselves. The Luzon arc is not subducted but is detached from the Philippine Sea Plate. Assuming that this example is typical of earlier accretion events it appears that arc-continent collision is an efficient method for building continental crust. Studies of orogenic belts yield several examples of this process active in the past, most notably in the Devonian Uralides (Brown et al., 2006) and in the Irish and Newfoundland Caledonides (Dewey and Ryan, 1990; Draut and Clift, 2001; Clift et al., 2003), as might be expected for a basic phase of the plate tectonic Wilson Cycle.

In addition to arc-passive margin collisions, oceanic arcs may become part of the continental crust as a result of collision with active continental margins. This happens when two subduction zones with the same polarity come into contact after the oceanic basin that separates them is subducted (Fig. 7). Unlike the arc-passive margin collision, in which collision is followed by orogeny and a flip of subduction polarity, there is no cessation of subduction in the arc-arc scenario. Instead the oceanic arc is plastered to the edge of the continental mass, effectively as a coherent block with no opportunity for major crustal loss by subduction. A number of the better known examples of oceanic arcs in mountain belts appears to have been accreted in this fashion, most notably the Jurassic Talkeetna Arc in SE Alaska (DeBari and Coleman, 1989; Clift et al., 2005; Greene et al., 2006) and the Cretaceous Kohistan Arc (Treloar et al., 1996; Khan et al., 1997; Jagoutz et al., 2007) of the western Himalayas. In both these examples the full crustal section is preserved, suggesting a very efficient accretionary process. Although collision may result in some deformation of the continental side of the accreting arc the forearc and trench of the colliding oceanic arc remain undeformed and magmatism is continuous, with the new continental arc being built on the foundations of the older oceanic arc. Subsequently the arc may be incorporated deeper into the continent due to outboard development of an accretionary complex, as in Alaska, or because of a continentcontinent collisional event, as in Kohistan.

\section{The composition of the continental crust}

Although arc accretion addresses the problem of maintaining continental crustal volumes it does not solve the problem that arc crust has long been recognized as being the wrong chemical composition to be a good building block for the continents. Seismic studies and lithologic and chemical analyses show that continental crust has a bulk andesitic composition (Taylor, 1967; Christensen and Mooney, 1995; Rudnick and Fountain, 1995). However, intra-oceanic island arcs are usually considered to have a bulk basaltic composition (Ewart and Hawkesworth, 1987; Holbrook et al., 1999). In addition, light rare earth element (LREE) patterns differ significantly between continental and intra-oceanic arc crust, this is despite the significant fractionation of magma under the arc, after melt extraction from the mantle wedge. Continental crust shows a characteristic strong LREE enrichment relative to the depleted mantle, which contrasts with the moderate or absent LREE enrichment seen in modern arcs.

Our estimates of arc production assume that the volumes of arc crust are converted into similar volumes of continental crust. While fractionation and delamination of dense lower crustal cumulates is important in making arc crust more siliceous than the primary melts we have already factored this process into the mass balance if the delamination process is relatively steady state during the building of arc crust (Behn et al., 2007). Because these delaminated masses are never in the crust for long, but are rather recycled continuously, we do not estimate them when measuring net crustal growth rates because these are generally determined on much longer timescales (see below). As for how the rest of the crust is transformed to more siliceous and LREE-enriched compositions, some studies have suggested that magmatism during the collision process itself is important to the chemical conversion and that therefore all the accreted arc crust is eventually incorporated into the continental mass without the need for further mass volume loss (Holbrook et al., 1999; Draut et al., 2002). In practice this means injection of siliceous, enriched melts into the pre-existing crust and delamination and recycling of more primitive, depleted, usually cumulate lower crust during the collision process.

Albarède (1998) argued that surface processes also play an important role in transforming accreted arc crust into average continental compositions. In particular, chemical weathering was advanced as being crucial in destroying mafic minerals and preferentially retaining siliceous components. Feldspars generally weather incongruently, meaning that they release cations and silica as dissolved load during their degradation (Blum, 1994). However, such reactions still produce solid residues, such as clays, which are carried as suspended material in rivers. These are then deposited as sediments in basins. In contrast, olivine weathers congruently, releasing dissolved $\mathrm{Mg}^{2+}$ and $\mathrm{SiO}_{2}$ but leaving no solid material behind (Dessert et al., 2003). As a general rule mafic minerals weather much faster than aluminosilicate minerals, so that on drainage basin scales, basaltic regions show much higher silicate weathering rates (Dessert et al., 2001). The net result of this is to transform accreted mafic arc crust into a more continental bulk composition through time.

Lee et al. (2008) estimate that $20 \%$ of new arc crust is removed by chemical weathering, while $40 \%$ is lost by delamination processes to allow the net composition to approach continental values. These authors envisage this dissolved mafic material being precipitated into altered oceanic crust and returned to the upper mantle by subduction processes. Based on our estimate of $3.8 \mathrm{~km}^{3} / \mathrm{a}$ arc production rate this would suggest export of around $0.75 \mathrm{~km}^{3} / \mathrm{a}$ of dissolved solute to the oceans, which is a rather high value. How much material is actually removed from continents to the oceans in dissolved form is debated. The global study of Meybeck (1976) estimated that dissolved loads 


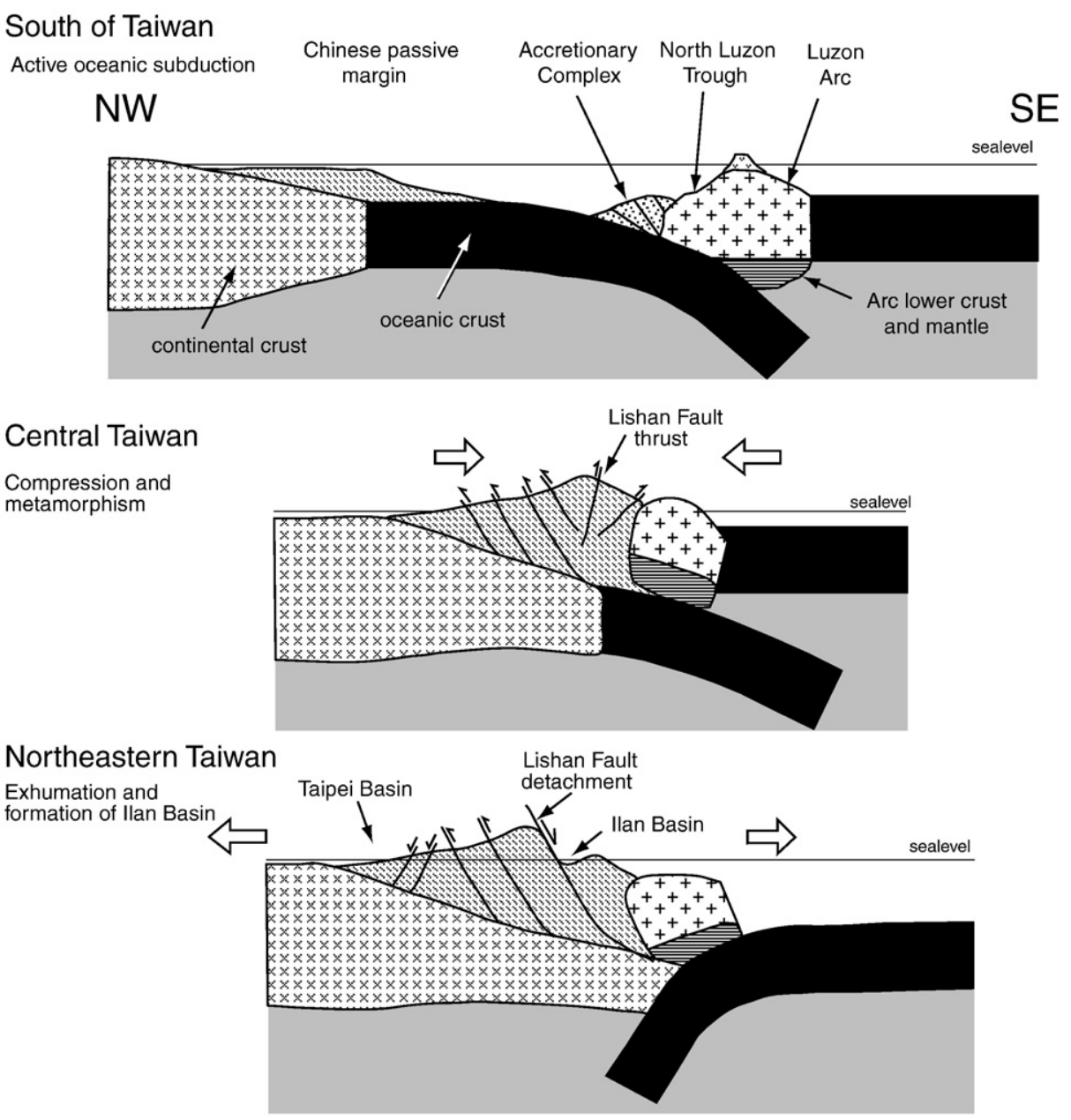

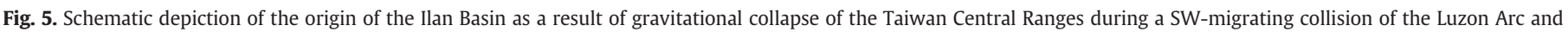
mainland China (Clift et al., 2008)

Re-printed with permission of the Geological Society of America.

were only $20 \%$ of the solid fluvial transport load, which we estimate below at $1.8 \mathrm{~km}^{3} / \mathrm{a}$, implying dissolved transport rates of only around $0.36 \mathrm{~km}^{3} / \mathrm{y}$. This overall budget has been largely confirmed by more recent studies (Summerfield and Hulton, 1994). More recent studies of weathering of arc crust in the Lesser Antilles Arc argue for lower chemical weathering transport of this type of crust. Rad et al. (2006) calculated that chemical weathering fluxes were at least seven times less than the solid clastic flux in this setting. Studies of rivers in more stable continent regions, such as Siberia (Huh and Edmond, 1999) and even in more tectonized Venezuela (Tosiani et al., 2004) would also support rather lower values of dissolved material flux than suggested by Lee et al. (2008). As a result we use a value of $0.4 \mathrm{~km}^{3} / \mathrm{a}$ in our mass balance calculations, following the 20\% estimate of Meybeck (1976) and Summerfield and Hulton (1994), while recognizing the uncertainties involved in this.

\section{Crustal losses during continent-continent collision}

\subsection{Subduction of continental crust}

Continent-continent collision events are usually not times of major crustal generation, but rather periods of reworking of preexisting crust. For example, despite the deformation and melting associated with collision $\mathrm{U}-\mathrm{Pb}$ dating of zircon crystallization $\left(>750{ }^{\circ} \mathrm{C}\right)$ from the granites of the Greater Himalaya shows no Cenozoic grains, but only early Paleozoic and Precambrian ages (Macfarlane, 1993; Parrish and Hodges, 1996; DeCelles et al., 2000;
Campbell et al., 2005). Instead collision events provide several methods by which continental crust may be returned to the upper mantle. One of the most obvious is that the collision of a passive margin with a trench system feeds a large volume of sediment, forming the sedimentary apron of the passive margin and overstepping on to oceanic lithosphere, deep under an arc system. The mass balancing described in Section 2 would suggest that this sediment is largely subducted and lost, with only a modest proportion of the sediment being accreted in thrust sheets within the mountains (Garzanti et al., 1987; Glennie et al., 1990; Corfield et al., 2005). Furthermore, the continental crystalline crust along the rifted margin is also at risk of being recycled. The presence of high-grade, eclogitic rocks in many orogenic belts indicates that some crust is underthrust to great depths $(>80 \mathrm{~km})$ and while some of this is returned to the surface some may also be lost (de Sigoyer et al., 2000; Leech and Stockli, 2000; Ratschbacher et al., 2000; Treloar et al., 2003).

Data from the Wopmay Orogen of NW Canada suggests that large pieces of the entire passive margin lithosphere can be recycled into the mantle during collisional events. A series of mafic dikes in the Wopmay foreland that postdate collision were interpreted to indicate a mechanical snapping and loss of the underthrust slab, driven by the weight of the connected oceanic slab (Fig. 8) (Hildebrand and Bowring, 1999). In this case much of the rifted crust on the margin is lost to the mantle. If this process were common in continentcontinent collision zones then this might facilitate large volumes of crustal reworking. Although the presence of mafic dike complexes of this variety is fairly rare outside the Wopmay Orogen, here we 
(A)

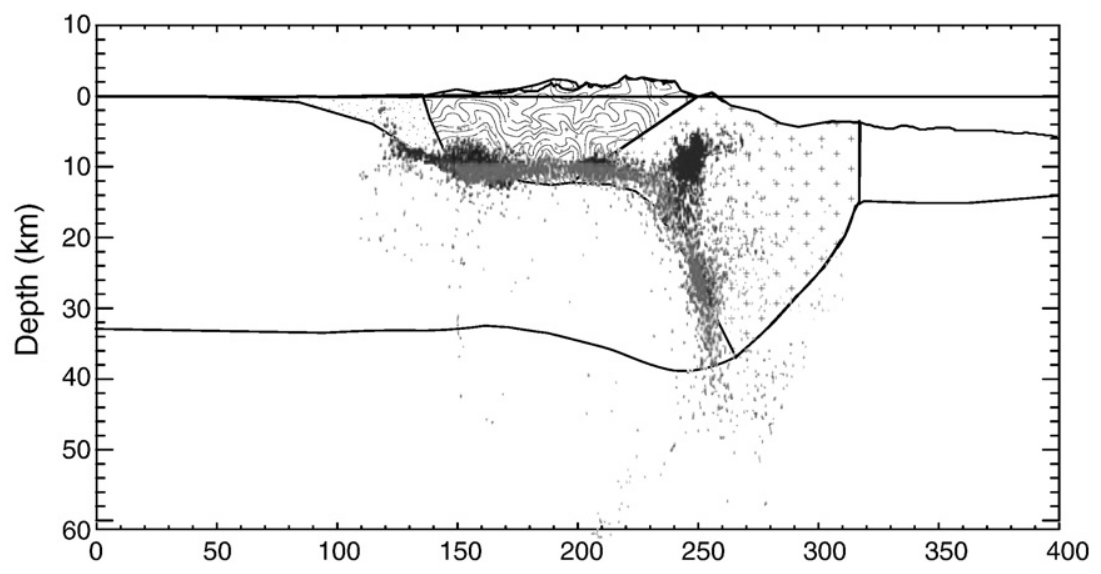

(B)

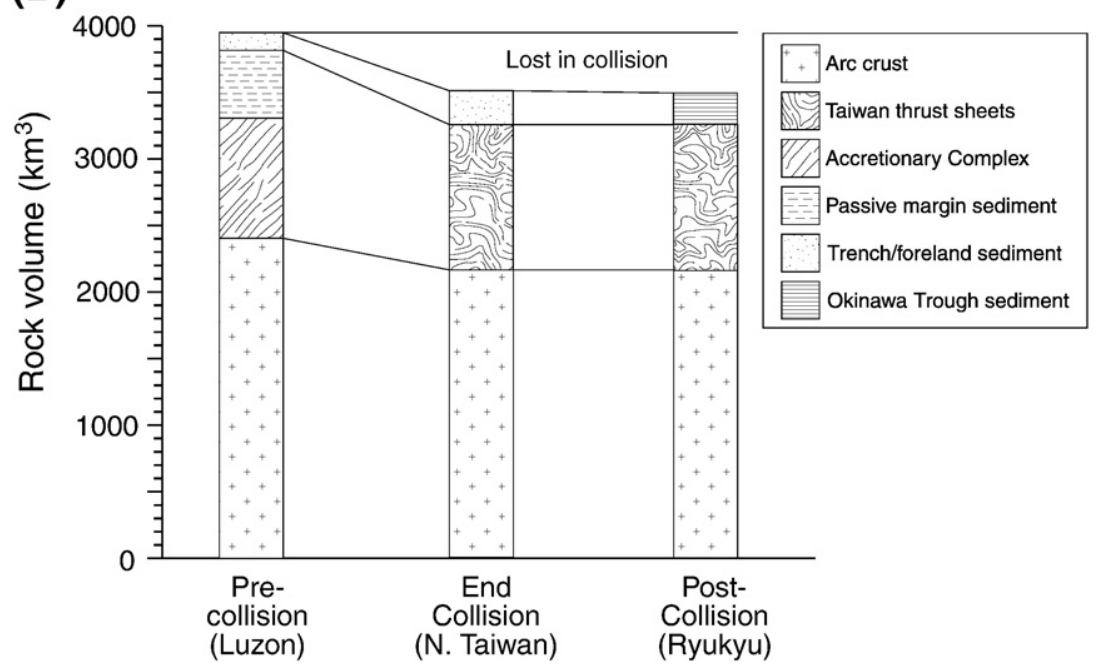

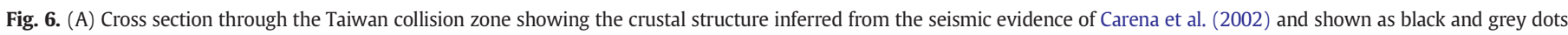

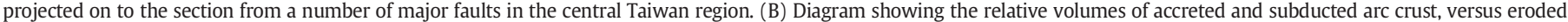

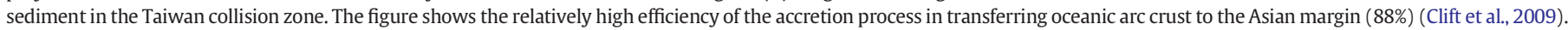
Modified and re-printed with permission of the Geological Society of London.

estimate the possible upper limits of long-term recycling by margin subduction assuming that loss is common, even if not evidenced but such intrusions, which might be exposed only late in the life of a mountain belt, after deep erosion. An estimate of the degree of crustal recycling possible during continental collisions can be derived by considering continent-continent and arc-continent collisions during the Cenozoic that involved subduction of a passive margin. We summarize the volumes of crust in these margins in Table 2.

The major Cenozoic collision zones include the Neotethyan belts of the Mediterranean, the Middle East and Himalaya, as well as Taiwan and the Ryukyu Arc, northern Borneo and the Australia-Papua New Guinea region. In total these sum to almost $16,000 \mathrm{~km}$ of rifted margin (Table 2). We assume a gradual thinning of the crust across these continental margins due to the progressive extension prior to continental break-up, and thus an average crustal thickness of $18 \mathrm{~km}$ (half normal continental (Christensen and Mooney, 1995)). We further assume that like the modern oceans around $50 \%$ of the subducted margins were volcanic (50-km-wide continent-ocean transition (COT)) and the remainder non-volcanic (150-km-wide COT). The sedimentary cover of the colliding margins may be partly imbricated into the orogen, but we otherwise estimate that all the margin crystalline crust oceanwards of normal unrifted crust may be subducted and recycled. We calculate that around $28 \times 10^{6} \mathrm{~km}^{3}$ would have been subducted since $65 \mathrm{Ma}$, resulting in a long-term average loss of $0.43 \mathrm{~km}^{3} / \mathrm{a}$. If we assume that all the subducted margins were non-volcanic, then the total subducted would increase to $4.2 \times 10^{9} \mathrm{~km}^{3}$ and the long-term recycling rate could be as high as $0.65 \mathrm{~km}^{3} / \mathrm{a}$.

\subsection{Erosional destruction of orogenic crust}

An alternative method of returning continental crust to the mantle is in the form of sediment via subduction zones. As noted above, the rate of sediment flux deep into trench systems is approximately $1.65 \mathrm{~km}^{3} / \mathrm{a}$, and this is provided to the ocean floor in the form of sediment delivered by rivers. Although collisional orogenies usually rework rather than create or destroy crust directly, they can result in the recycling of crust to the mantle as a result of surface erosion, which eventually exports all the "excess" crust from the mountain belt and delivers it to submarine fans that are built on oceanic crust where it may subsequently subducted. When that sedimentation occurs on passive margins there may be some delay in the recycling, but rapid return to the mantle is possible along active margins. The Bengal Fan, which is the largest sediment mass on Earth, is eroded from the Himalaya and is being subducted along the Andaman-Sumatra Trench, even while orogenic erosion is still ongoing. Estimates of the accretion 
$180 \mathrm{Ma}$

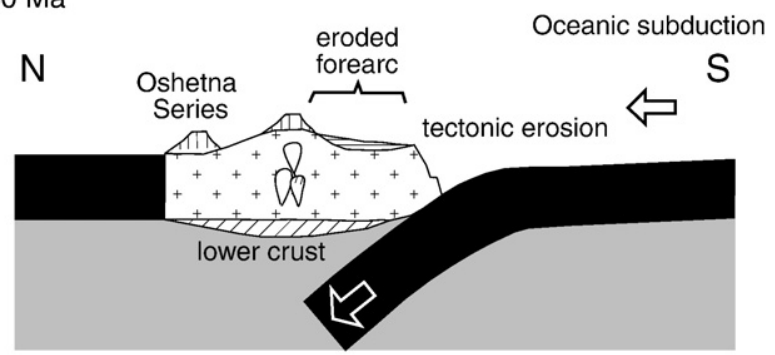

$172 \mathrm{Ma}$

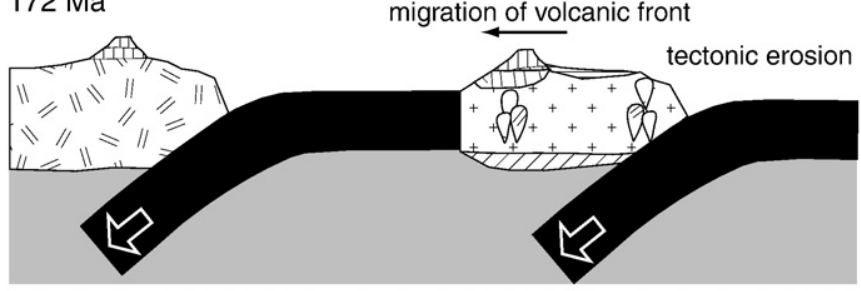

$155 \mathrm{Ma}$

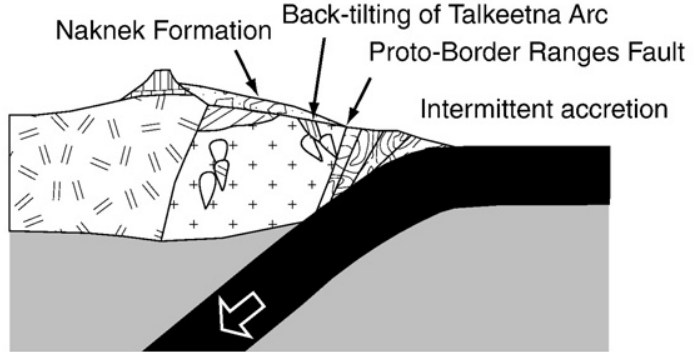

Fig. 7. Cartoon showing a typical arc-arc collision event using the examples of the Jurassic Talkeetna arc in south-central Alaska (Clift et al., 2005). Deformation is concentrated between the colliding arcs, while the trench to the south remains open and active.

Re-printed with permission of the Geological Society of America.

efficiency of the Andaman Trench lie at 28\% (Clift and Vannucchi, 2004), while we here estimate that of the $72 \%$ subducted only $6 \%$ is recycled into the arc (Table 1 ). In this fashion Himalayan mountain building is responsible for significant loss of continental crust back to the mantle.

Tectonic forces are only capable of sustaining high orogenic elevations while they are still active because erosion will tend to remove "excess" crust (Ahnert, 1970; Pinet and Souriau, 1988) and thin the crust back to the equilibrium values of ca. $38 \mathrm{~km}$, close to sealevel (Christensen and Mooney, 1995). In particular, it has been shown that erosion rates tend to increase sharply once local topographic relief exceeds ca. $1 \mathrm{~km}$ (Burbank et al., 1996), suggesting that erosion will rapidly reduce mountains to altitudes of $<1 \mathrm{~km}$ and then more slowly remove the remainder as the land surface is reduced to the stable freeboard value above the ocean surface (Harrison, 1994). What is clear is that regions where the crust is much thicker than ca. $38 \mathrm{~km}$ are areas of active or very recent tectonism, while older mountain belts have typically been eroded to their roots. In Table 3 we present data used to estimate how long it would take to remove the excess crust of four major modern mountain belts based on longterm erosion rates derived from the sedimentary depocenters surrounding them. In each case the volume of eroded sediment was either compiled from the literature, or was calculated from regional geological cross sections based on seismic surveys (Whitehead and Clift, 2009). For most sedimentary sections thicker than $5 \mathrm{~km}$ a $20 \%$ value is used as a reasonable approximation for the bulk porosity (Sclater and Christie, 1980), which must be corrected for in order to determine eroded rock volume. Where the sedimentary basin in question was older than the orogen care was taken only to estimate that part of the record that was derived by erosion from the mountain chain. Once total eroded rock volumes were calculated a long-term
(A)
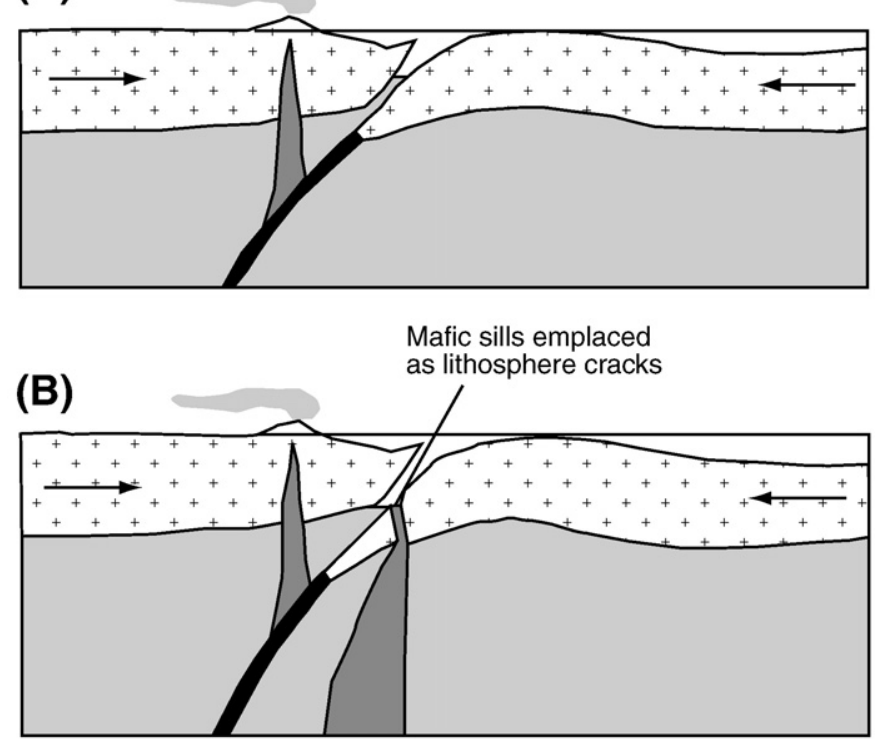

(C)

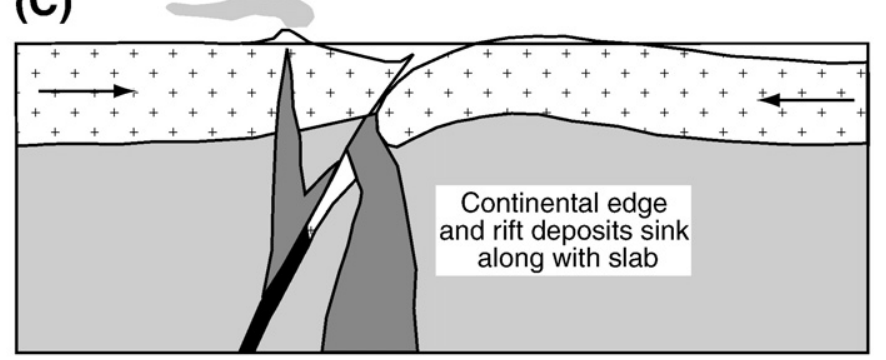

Fig. 8. Cartoon of the slab break-off process during continent-continent collision, as shown for the Wopmay Orogen, Canada.

Figure is modified from Hildebrand and Bowring (1999).

erosion rate was determined by dividing by the age of mountain building.

Calculation of the excess crustal mass was performed by determining the area and crustal thickness of the mountain belt in order to calculate the volume of rock in the modern system. Then

Table 2

Estimates of the lengths of the passive margin systems involved in continental collisions during the Cenozoic, together with calculation of approximate volume of continental crust subducted into the mantle as a result. From Clift et al. (2009).

Re-printed with permission of the Geological Society of London.

\begin{tabular}{|c|c|c|c|c|c|}
\hline \multicolumn{4}{|c|}{ Cenozoic orogen } & \multicolumn{2}{|c|}{$\begin{array}{l}\text { Length of subducted margin } \\
(\mathrm{km})\end{array}$} \\
\hline \multicolumn{4}{|l|}{ Alboran Sea } & \multicolumn{2}{|l|}{1300} \\
\hline \multicolumn{4}{|c|}{ Pyrenees } & \multicolumn{2}{|l|}{450} \\
\hline \multicolumn{4}{|c|}{ Alps-Appennines-Hellenides } & \multicolumn{2}{|l|}{3000} \\
\hline \multicolumn{4}{|c|}{ Turkey-Zagros } & \multicolumn{2}{|l|}{3100} \\
\hline \multicolumn{4}{|l|}{ Himalaya } & \multicolumn{2}{|l|}{2700} \\
\hline \multicolumn{4}{|c|}{ Taiwan-Ryukyu } & \multicolumn{2}{|l|}{1100} \\
\hline \multicolumn{4}{|c|}{ Borneo } & \multicolumn{2}{|l|}{1300} \\
\hline \multicolumn{4}{|c|}{ Australia-Papua New Guinea } & \multicolumn{2}{|l|}{2800} \\
\hline \multicolumn{4}{|c|}{ Total } & \multicolumn{2}{|l|}{15,750} \\
\hline Margin type & $\begin{array}{l}\% \text { of } \\
\text { total }\end{array}$ & $\begin{array}{l}\text { Length } \\
\text { of margin } \\
(\mathrm{km})\end{array}$ & $\begin{array}{l}\text { Width } \\
\text { of COT } \\
(\mathrm{km})\end{array}$ & $\begin{array}{l}\text { Average crustal } \\
\text { thickness } \\
(\mathrm{km})\end{array}$ & $\begin{array}{l}\text { Volume } \\
\left(\mathrm{km}^{3}\right)\end{array}$ \\
\hline Volcanic & 50 & 7875 & 50 & 18 & $7,087,500$ \\
\hline $\begin{array}{l}\text { Non-volcanic } \\
\text { Total }\end{array}$ & 50 & 7875 & 150 & 18 & $\begin{array}{l}21,262,500 \\
28,350,000\end{array}$ \\
\hline
\end{tabular}


Table 3

Calculated rates of orogenic erosion for the Tibet-Himalayan plateau, the Altiplano Plateau, the European Alps and the Anatolia-Iranian Plateau.

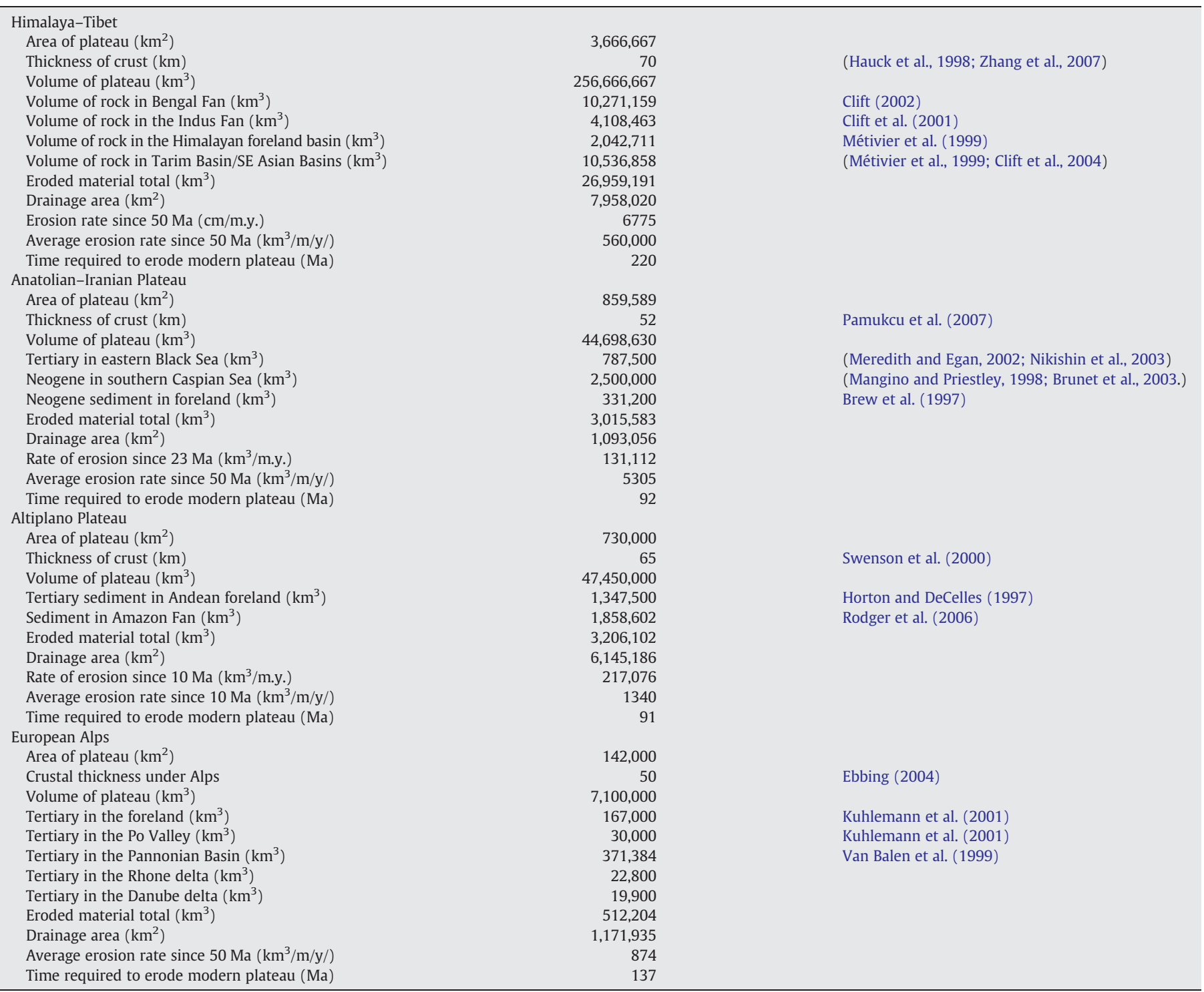

assuming that $38 \mathrm{~km}$ is an equilibrium value for the continental crust we determined how much of the modern crust would have to be removed to return the mountains to that equilibrium value. Applying the long-term erosion rate then provides a rough estimate of how long it would take to eliminate the orogenic topographic and crustal excess if the tectonic forces constructing the range were to cease today. Here we consider the Himalaya-Tibetan system, the AnatolianIranian Plateau, the Andean-Altiplano Plateau and the European Alps. Table 3 shows that at the high end it would take 220 million years to destroy the Tibetan Plateau, but only 91 million years to remove the Altiplano. Naturally there are many caveats to these estimates. For example, the erosion of Tibet has accelerated greatly with the start of the Asian monsoon around $25 \mathrm{Ma}$ (Clift, 2006). Nonetheless, the exercise gives a general impression that mountains have a longevity of 100-200 million years, but likely not much longer. This estimate is supported by geological evidence. For example, the mountains formed by the Acadian Orogeny in eastern North America after closure of the Iapetus Ocean reached peak metamorphism around $395 \mathrm{Ma}$ (Armstrong et al., 1992), but were truncated by a peneplain erosion unconformity of Late Carboniferous age $(\sim 320 \mathrm{Ma})$ in western Ireland
(Graham, 1981), suggesting 75 million years was required to remove the excess crust by erosion. Surface processes are quite efficient at recycling continental crust over timescales much shorter than the age of the planet.

\subsection{Erosional destruction of cratonic crust during the Cenozoic}

A more general estimate of how fast surface processes rework continental crust can be derived by a global estimate of how rapidly rivers deliver materials to the oceans where they may be subducted. Milliman (1997) estimates that the modern river systems deliver around $6.5 \mathrm{~km}^{3} / \mathrm{a}$ of sediment to the oceans, yet there are reasons to believe that this is not a representative average rate for long periods of geologic time. The modern Earth appears to be somewhat more mountainous and thus erosive compared to the Earth at $65 \mathrm{Ma}$, prior to the building of the High Andes and Tibet, as well as much of the Alpine-Himalayan belts (Patzkowsky et al., 1991; Dercourt et al., 1993). These cycles of supercontinent accretion and destruction have been recognized in thermochronology, especially zircon dating, as resulting in a rock record of uneven and biased preservation 
(Hawkesworth et al., 2009). Furthermore, compilations of global sediment budgets indicate that erosion rates since the initiation of Northern Hemispheric Glaciation are much elevated compared to those before ca. 3 Ma (Métivier et al., 1999; Zhang et al., 2001). It should also be realized that modern rivers are not in equilibrium, but still adjusting to climate change after the Last Glacial Maximum (ca. $20 \mathrm{ka}$ ). Stronger summer rainfall seems to have increased sediment flux, especially in those regions under the influence of the Asian monsoon (Goodbred and Kuehl, 2000; Giosan et al., 2006). Most recently anthropogenic processes, especially agriculture, have increased the sediment flux to rivers.

Here we calculate the long-term rates of erosion for the Cenozoic because over this time period we have reasonable structural and age control over continental margin sediment masses, at least for a number of the world's major river systems. It is only sediment eroded and deposited in the ocean basins that is significant for quantifying crustal recycling, rather than terrestrial basins, in which crust is simply redistributed within the continents. Because it is not practical to directly measure the total global volume of Cenozoic sediment we make longterm, erosion budgets for a number of major drainages and then extrapolate these results to those parts of the world where surveying is insufficient to generate reliable records. Fig. 9 shows a map with those drainages analyzed here and the regions affected by major Cenozoic mountain building, where the crust is thicker than equilibrium.

Eroded rock volumes are calculated from the volumes of sedimentary rock using a suitable porosity correction estimate, which depends on the total thickness of sediment (Sclater and Christie, 1980). We also make a correction for major carbonate masses, although close to the deltas of major rivers this is rarely a significant issue within the errors of the general estimate. In some delta and submarine fan systems there has been significant seismic analysis performed and sediment volume estimates already made (e.g., many of the Asian delta systems (Métivier et al., 1999; Clift et al., 2004)). In these cases we simply use the published volumes for Cenozoic sediment masses. However, in other systems we have had to make our own volume approximation. In these cases (e.g. the Nile) we use long, regional seismically based cross-sections that have been converted to depth (Fig. 10). This allows the cross sectional areas of sediment dated as Cenozoic to be determined. If more than one regional-scale section was available then these were combined to improve the average estimate and account for lateral variability. The width of the fan, or its radius, depending on the geometry of the system, is then used to calculate an estimate of the total volume of sediment in the submarine fan (Table 4). Although the list of rivers is not exhaustive, being constrained mostly by lack of published offshore sedimentary data, we have attempted to include rivers from all continents and spanning several climate zones.

As has been widely recognized and also confirmed here mass transfer rates in areas of significant topographic relief (generally $>1 \mathrm{~km}$ of local relief) are subject to much faster physical erosion than low-lying, tectonically passive areas (Burbank et al., 1996). As a general rule those regions affected by Cenozoic orogenesis have been regions of faster erosion during that period, while stable cratonic regions have delivered less rock to the oceanic crust (Fig. 11). However, in some systems, such as the Alps most of the sediment is trapped within continental foreland basins and does not reach the oceanic basins, resulting in moderate rock export rates, while in others, such as the Altiplano the rate of rock export to the ocean has been high because of a lack of accommodation space onshore.

The efficiency of each basin in removing rock to the oceanic crust can be assessed in Fig. 12 where we compare the area of the basin with the volume of rock eroded from it during the Cenozoic. Model lines show the ratio of basin area to rock volume. These show that not only is the Himalaya-Tibetan Plateau the greatest producer of sediment, but it is also the most efficient major system, yielding more eroded rock per unit area than any other large basin, although the Anatolian-Iranian Plateau comes a close second. In contrast, the Orange, Nile, the Murray-Darling and Paraná Rivers are noteworthy for having relatively small deltas compared to the area of their drainage basins. The simplest explanation of this is that their hinterlands are not very erosive, but the extremely low values could also reflect drainage capture and reorganization and/or the switching of deltas over large distances (Burke, 1996; Burke and Gunnell, 2008).

The average depth of erosion calculated for each river basin has no direct physical reality because sediment is usually generated in a limited part of the basin and not evenly across the drainage. For the purpose of our study we simply derive an average basin-wide erosion depth and rate for those rivers that drain stable continental areas. We take a different approach for rivers draining mountainous sources because most provenance data in these settings indicate that the vast majority of the sediment is eroded from the mountains, with relatively insignificant quantities being derived from the flood plains. As a result we determine the rate of erosion using the volume of sediment on the oceanic crust divided by the area of the mountain source regions, not including the lowland flood plains. This provides

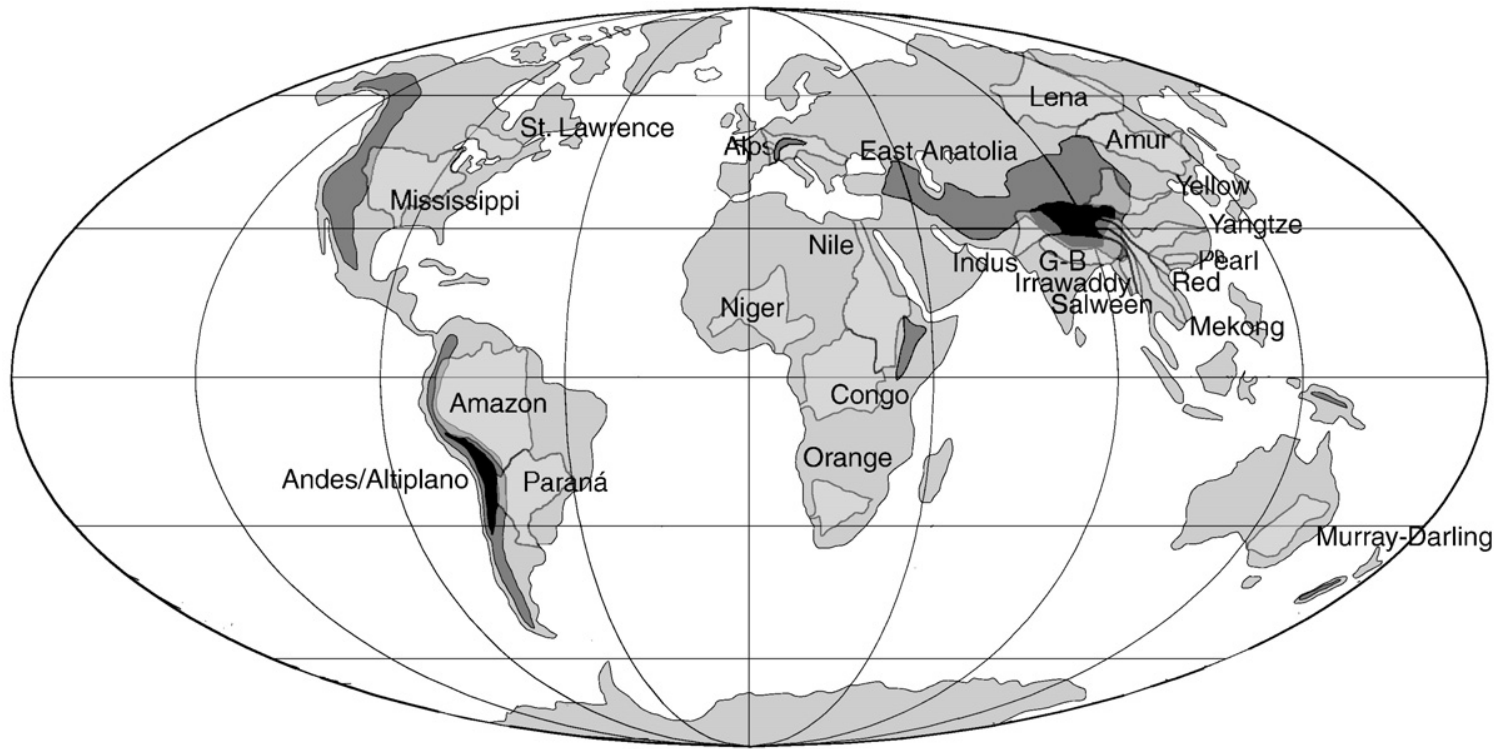

Fig. 9. Map of the Earth showing the location and extent of the map drainage basins used in the global erosional compilation. 


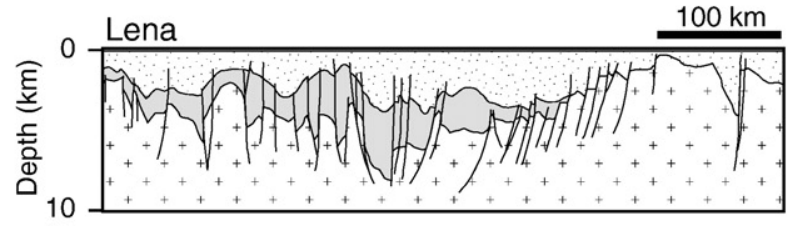

\section{Cenozoic sedimentary rocks}

Mesozoic sedimentary rocks

Basement
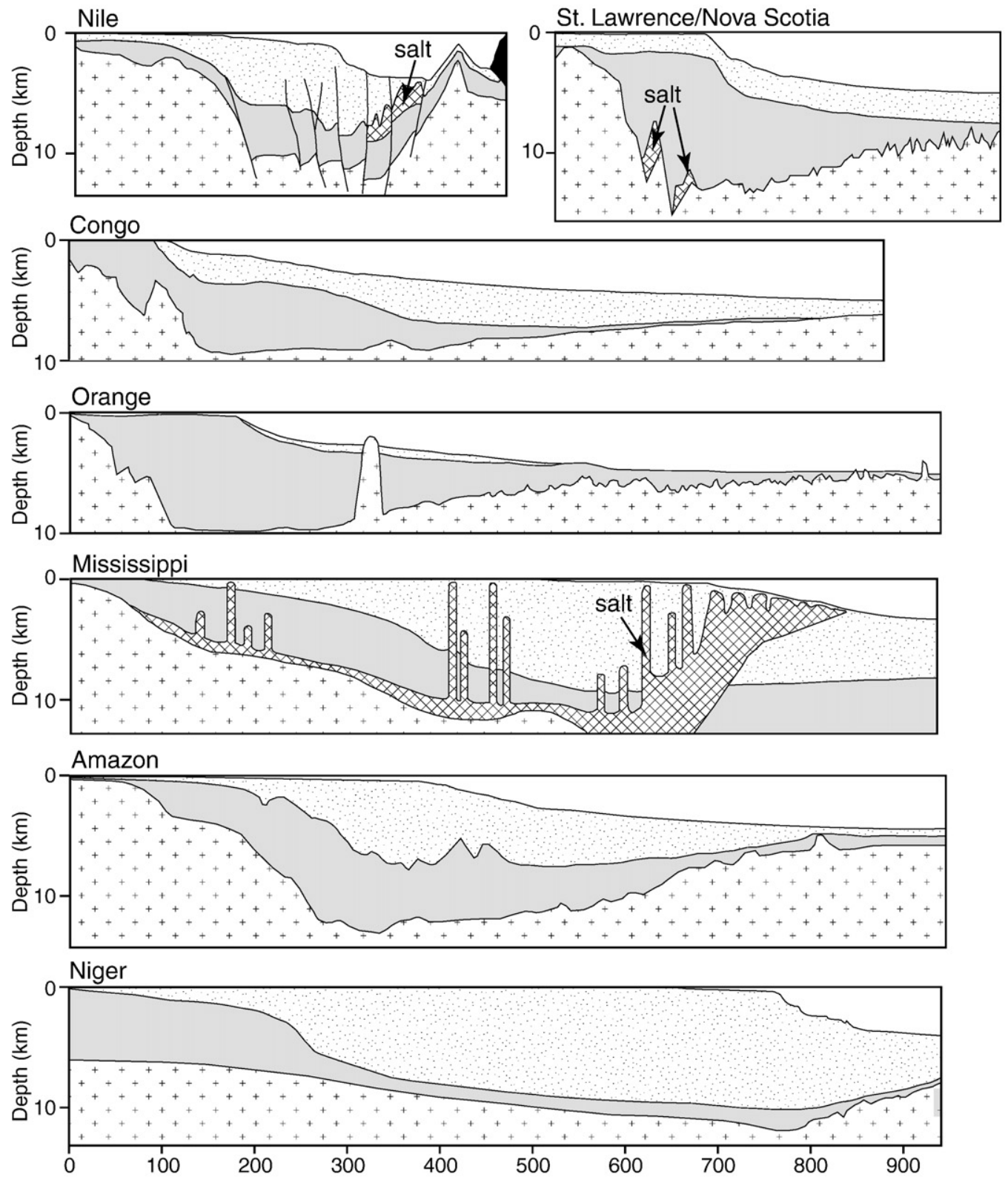

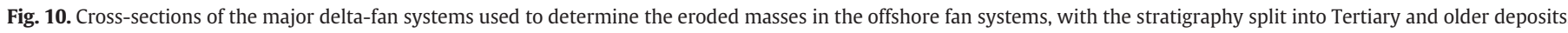
References for the origin of each fan section is provided in Table 4.

an estimate of how rapidly the mountains alone are being exported to the oceanic crust. Although the mountains have higher rock export rates than the lowlands this number can be affected by a number of processes. The rate of rock export per unit area from Tibet is lower than those for the Altiplano and for Anatolia principally because of the wide areas of weakly eroding terrane on the high plateau of Tibet itself, while rapidly eroding ranges dominate to a greater extent in the Amazon basin and around Anatolia. The net export of rock from source to ocean may also be reduced if there are major sedimentary basins within the continents that prevent loss of continental crust to the ocean basins. This is the case in the European Alps where much of the sediment bulk lies in the Alpine foreland and Pannonian Basins.
However, unlike our calculation for the life span of the Andes, here we are only concerned with the volumes of sediment reaching the continental margin that are subductable and not material sequestered within continental basins.

In order to generate a global surface erosion estimate we split the continental regions into two groups, "elevated, orogenic" and "low lying, stable" (Fig. 9), which we estimate to account for 17\% and $83 \%$ respectively of the currently exposed continental area. We then assign each of the river basins considered to one of these groups (Fig. 12). The sediment budgets for the Himalaya-Tibetan Plateau, the Altiplano Plateau, the Anatolian-Iranian Plateau and the European Alps, as determined above, are used to make estimates for sediment 
Table 4

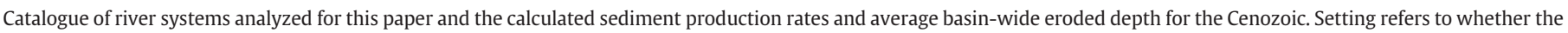
river is dominated by erosion from tectonically stable continental regions or mountains formed during the Cenozoic.

\begin{tabular}{|c|c|c|c|c|c|c|c|c|}
\hline River system & $\begin{array}{l}\text { Total } \\
\text { sedimentary } \\
\text { volume } \\
\left(\mathrm{km}^{3}\right)\end{array}$ & $\begin{array}{l}\text { Age of } \\
\text { delta } \\
\text { initiation } \\
\text { (Ma) }\end{array}$ & $\begin{array}{l}\text { Rock volume } \\
\text { eroded in } \\
\text { Cenozoic } \\
\left(\mathrm{km}^{3}\right)\end{array}$ & $\begin{array}{l}\text { Modern } \\
\text { basin/source } \\
\text { area } \\
\left(\mathrm{km}^{2}\right)\end{array}$ & $\begin{array}{l}\text { Cenozoic } \\
\text { erosion } \\
\text { rate } \\
(\mathrm{cm} / \mathrm{m} . \mathrm{y} .)\end{array}$ & $\begin{array}{l}\text { Eroded } \\
\text { depth in } \\
\text { Cenozoic } \\
(\mathrm{km})\end{array}$ & Setting & Reference \\
\hline Congo & $1,914,644$ & 120 & 921,132 & $3,730,881$ & 380 & 0.25 & Stable & (Piper and Normark, 2001; Lavier et al., 2001) \\
\hline Niger & $2,580,482$ & 120 & $1,602,901$ & $2,261,741$ & 1090 & 0.71 & Stable & Tuttle et al. (1999) \\
\hline Orange & $1,004,960$ & 120 & 59,993 & 941,351 & 98 & 0.06 & Stable & (Emery et al., 1975; Brown, 1995) \\
\hline Nile & $1,136,855$ & 200 & 306,190 & $3,254,853$ & 145 & 0.09 & Stable & Aal et al. (2001) \\
\hline St. Lawrence & $1,623,868$ & 175 & 603,151 & $1,049,636$ & 884 & 0.57 & Stable & Wu et al. (2006) \\
\hline Mississippi & $4,870,748$ & 210 & $2,479,615$ & $2,981,076$ & 1280 & 0.83 & Stable & Galloway et al. (1991) \\
\hline Parana & $1,027,516$ & 120 & 232,628 & $2,582,704$ & 139 & 0.09 & Stable & (Stoakes et al., 1991; Abreu, 1998) \\
\hline Lena & 825,000 & 65 & 687,500 & $2,306,743$ & 459 & 0.30 & Stable & Dracheva et al. (1998) \\
\hline Amur & 680,000 & 21 & 566,667 & $1,929,955$ & 429 & 0.29 & Stable & Gnibidenko and Khvedchuk (1982) \\
\hline Murray-Darling & 132,500 & 65 & 110,417 & $1,050,116$ & 162 & 0.11 & Stable & (Abele et al., 1976; Brown and Stephenson, 1991) \\
\hline Himalaya-Tibet System & $32,351,029$ & 50 & $14,379,622$ & $3,700,000$ & 7800 & 3.92 & Orogenic & (Clift, 2002; Métivier et al., 1999) \\
\hline European Alpine System & 614,645 & 50 & 512,204 & $1,171,935$ & 670 & 0.33 & Orogenic & (Kuhlemann et al., 2001; Van Balen et al., 1999) \\
\hline Andes-Altiplano System & $3,847,323$ & 10 & $1,858,602$ & $1,100,000$ & 16,900 & 1.69 & Orogenic & (Rodger et al., 2006; Horton and DeCelles, 1997) \\
\hline Eastern Anatolian System & $3,618,700$ & 23 & $3,300,000$ & 860,000 & 16,600 & 3.82 & Orogenic & $\begin{array}{l}\text { (Meredith and Egan, 2002; Nikishin et al., 2003; } \\
\text { Mangino and Priestley, 1998; Brunet et al., 2003) }\end{array}$ \\
\hline
\end{tabular}

production rates in orogenic regions when we consider the area of mountainous terrane drained by the rivers in question. Because these systems comprise several rivers draining different parts of each mountain range this approach should result in a good global estimate for orogenic rock export rates. For example the Himalaya-Tibetan grouping includes the sediment-laden Ganges-Brahmaputra and the less productive Pearl and Yangtze Rivers. In eastern Anatolia we do not consider the sediment in the foreland basin of Mesopotamia, but crucially do include the sediments in the oceanic southern Caspian Sea and the eastern Black Sea, east of the Mid Black Sea Ridge (Table 4).

In order to derive a global erosion estimate we must also account for sediment from untectonized regions. We add together the Cenozoic erosional fluxes from rivers draining stable regions and divide this value by the total area of those drainage basins. This provides an average Cenozoic erosion rate for this type of river basin. In the absence of other data we assume that other areas of the stable continental crust also erode at these rates and so we extrapolate our estimated rates over all that part of the Earth's surface that was not tectonized during the Cenozoic (Table 5). Similarly, we determine an average erosion rate for those areas of the Earth that were affected by Cenozoic orogeny and faster erosion. We estimate an average sediment yield for these areas and again extrapolate the results to all such regions. Combination of the mountainous and cratonic basins yields an estimate of how much sediment has been exported to the global ocean from the continents by rivers during the Cenozoic. The long-term average is ca. $1.77 \mathrm{~km}^{3} /$ a. Although this value is much less than the modern $6.5 \mathrm{~km}^{3} /$ a estimated by Milliman (1997), it is close to the $1.6 \mathrm{~km}^{3} / \mathrm{a}$ estimated for the sediment flux to the trenches, suggestive that the total amount of sediment in the oceans should be close to equilibrium.

\section{Lower crustal delamination}

We now consider lower crustal delamination (Kay and Kay, 1993) as another major mechanism for the recycling of crustal material back into the mantle. In doing so we do not consider the apparently steadystate loss of dense lower crustal cumulates from the bottom of active arc systems (Jull and Kelemen, 2001; Behn and Kelemen, 2006). In

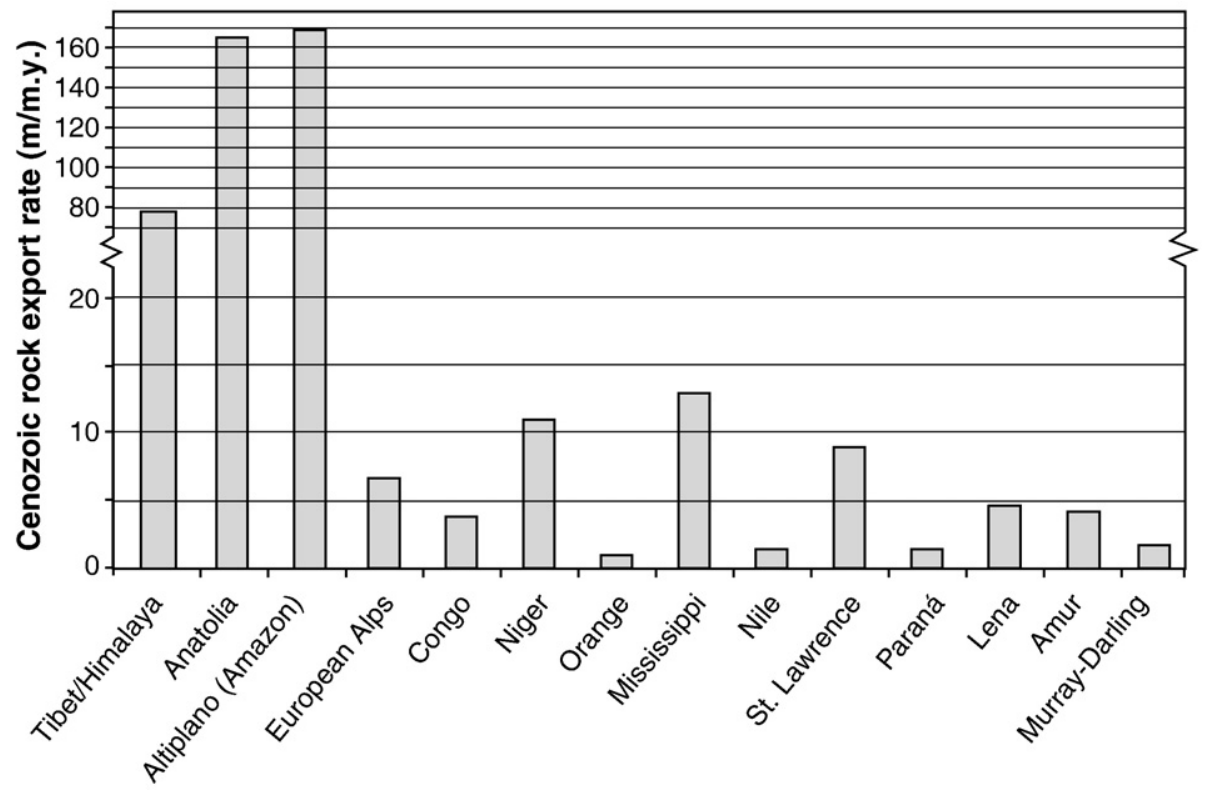

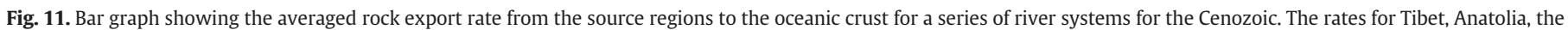
Altiplano and the Alps are average over the many rivers that drain those orogenic systems. Data is from Table 4. 


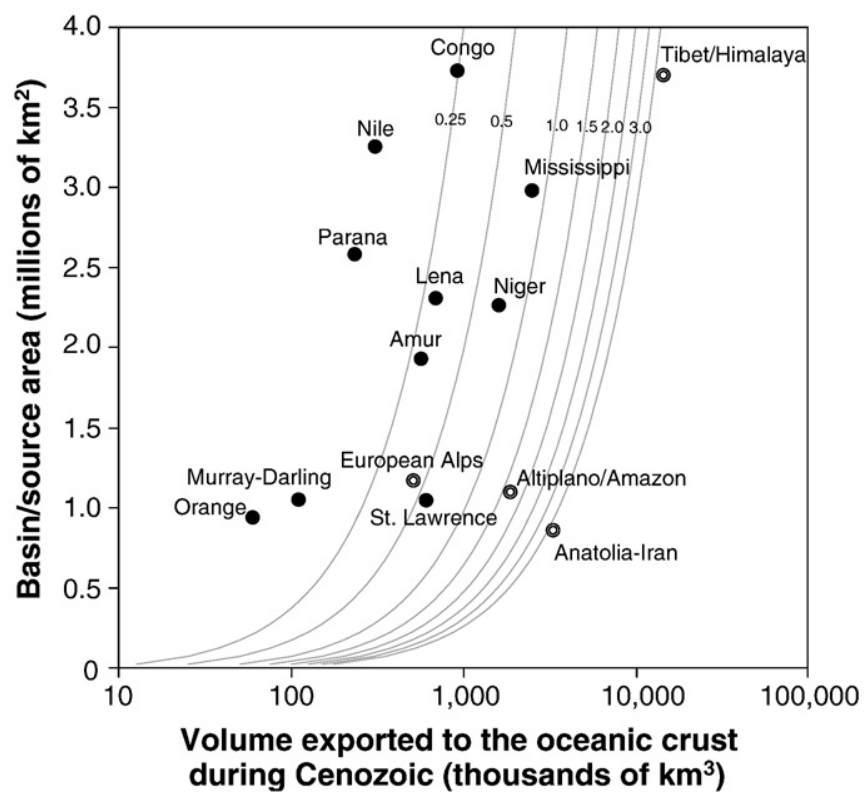

Fig. 12. Plot showing the relationship between total eroded volumes in the fan systems and the area of the drainage basin feeding those systems. Data is from Table 4. Grey curved lines show the ratio of eroded rock volume to basin areas. Basins draining elevated, orogenic crust are shown with circles, while those draining only low lying, stable terrain are represented by black dots.

those cases the lower crust is formed by fractional crystallization of arc melts derived from the mantle wedge and as a result the residence time of such material in the crust is too short to be worth considering as a net loss or gain to the total crust volume, since it cannot be measured. Seismic evidence now suggests that delamination of lower arc crust is a common process (Behn et al., 2007), which is consistent with the need to fractionate much larger volumes of mafic melt than the volumes of andesitic crust observed in most oceanic arcs. Because these delaminated masses are returned to the mantle they do not contribute to the long-term growth of the continental crust, which we focus on here.

In this section we consider the loss of lower crust, usually eclogitic, that has been resident in the crust for long periods of time and which is then lost catastrophically in one or a series of discrete events. We do not dwell here on why or precisely how fast the delamination event is, but simply try to assess its impact on the total crustal budget. Identifying

\section{Table 5}

Calculation of the global sediment production rate for the Cenozoic based on a limited number of observations from both stable continental and orogenic river systems and extrapolated to all such regions of the present continents.

\begin{tabular}{llr}
\hline & Measured & Projected \\
\hline $\begin{array}{l}\text { Stable crust } \\
\text { Total drained area }\left(\mathrm{km}^{2}\right)\end{array}$ & $22,089,000$ & $123,710,000$ \\
$\begin{array}{l}\text { Total eroded volume since } 65 \mathrm{Ma}\left(\mathrm{km}^{3}\right) \\
\text { Average depth eroded since } 65 \mathrm{Ma}(\mathrm{km})\end{array}$ & $\begin{array}{l}7,570,200 \\
\end{array}$ & $42,396,800$ \\
Orogenic & & \\
Total drained area $\left(\mathrm{km}^{2}\right)$ & $6,831,935$ & $24,719,413$ \\
Total eroded volume since $65 \mathrm{Ma}\left(\mathrm{km}^{3}\right)$ & $20,050,428$ & $72,546,772$ \\
Depth eroded since $65 \mathrm{Ma}(\mathrm{km})$ & 2.93 & \\
& & $\%$ \\
Global & Measured & $17 \%$ \\
\hline $\begin{array}{l}\text { Area of modern continents }\left(\mathrm{km}^{2}\right) \\
\text { Area of Cenozoic mountains }\left(\mathrm{km}^{2}\right)\end{array}$ & $148,429,000$ & $83 \%$ \\
$\begin{array}{l}\text { Area of stable crust }\left(\mathrm{km}^{2}\right) \\
\text { Total eroded since } 65 \mathrm{Ma}\left(\mathrm{km}^{3}\right)\end{array}$ & $24,719,400$ & \\
Rate of recycling $\left(\mathrm{km}^{3} / \mathrm{m} . \mathrm{y}.\right)$ & $114,709,600$ & \\
\hline
\end{tabular}

when such an event might have occurred is not altogether easy, but most authors agree that the process is accompanied by topographic uplift, as the dense crustal root is released and also by magmatism (Kay and Kay, 1993). In particular, the generation of adakites, which are andesites and dacites with extreme light rare earth element (REE) enrichment and are often associated with partial melting of subducted eclogitic basalt, is often interpreted as evidence of lower crustal and mantle lithospheric delamination (Stern and Kilian, 1996; Polat and Kerrich, 2002; Elkins-Tanton, 2005). Unfortunately the term adakite is often used to refer to both composition and genesis interchangeably and even the compositional definition is not uniform within the community, so care must be used when using presence of these rocks as a sure indicator of delamination (Kelemen et al., 2003).

The best known example of delamination is from the Jurassic of NE China (Gao et al., 1998, 2004). In this place adakites, andesites and dacites were erupted within a zone of continental extension. As in others cases there is debate over whether the delamination actually involved the crust or just the mantle lithosphere, as appears to have been the case in Miocene Tibet and in modern New Zealand (Molnar and Houseman, 2004). However, the lavas in North China contain Archean zircons and have neodymium and strontium isotopic compositions overlapping those of eclogitic xenoliths derived from the lower crust of the North China Craton (Gao et al., 1998). These data argue strongly for the involvement of the lower crust in petrogenesis. Eclogitized lower crust was lost back into the mantle around $120 \mathrm{Ma}$, during the Early Cretaceous, following a crustal thickening event in the Triassic (Menzies et al., 1993).

Other sites of proposed lower crustal delamination events include the Sierra Nevada in the western USA (Ducea and Saleeby, 1998; Jones et al., 2004; Zandt et al., 2004), the Alboran Sea of the western Mediterranean (Lonergan and White, 1997; Platt et al., 2003; BoothRea et al., 2007) and the Altiplano and Puna Plateaus of the Andes (Kay et al., 1994; McQuarrie et al., 2005). In the latter case extreme crustal thickening over the dipping slab resulted in instabilities in the eclogitic lower crust that led to Pliocene continental lithospheric delamination (Fig. 13) (Kay and Coira, 2008). Evidence for delamination comes from Pliocene to Recent ignimbritic eruptions of the Cerro Galan, Argentina (Francis et al., 1978), as well as a concentration of primitive mafic lavas associated with normal and strike-slip faults, high regional elevation, seismic evidence for a thin underlying lithosphere and an abnormally hot subducting slab (Kay et al., 1999).

The major problem encountered when estimating the volume of crust lost via crustal delamination is measuring how great a thickness of material has been recycled. In each case the area of delamination is quite well defined by the extent of topographic uplift and unusual volcanic compositions. Delamination may involve both lower crustal eclogites and the mantle lithosphere. While chemistry can inform us of the presence of lower crust in the delaminating slab it is more difficult to estimate quite how much has been removed. Some estimates have been made based on the known depths at which eclogites can form and modern seismically determined estimates of the modern crustal thickness (see Table 6 for references). Only rarely can delaminating slabs be imaged and measured, and even then the proportion of lower crust in the slab is not known (Gurria and Mezcua, 2000; Forsyth and Yang, 2005). In this work we use the estimates derived from the specific site studies, ranging from 5-10 km under North China (Gao et al., 1998) to as much as $25 \mathrm{~km}$ under the Alboran Sea (Platt et al., 2003). As Table 6 shows, by far the largest delamination events are in North China and the Puna-Altiplano Plateau in terms of their ability to recycle crust to the mantle. When averaged over the 120 million years since the North China event the rate of recycling by this method is estimated at around $1.1 \mathrm{~km}^{3} / \mathrm{a}$. However, this number is poorly constrained because of uncertainties in the thickness of the delaminated slab and may be somewhat larger if Tibet has been a site of major eclogitic loss, in addition to the widely recognized lithospheric mantle delamination. 


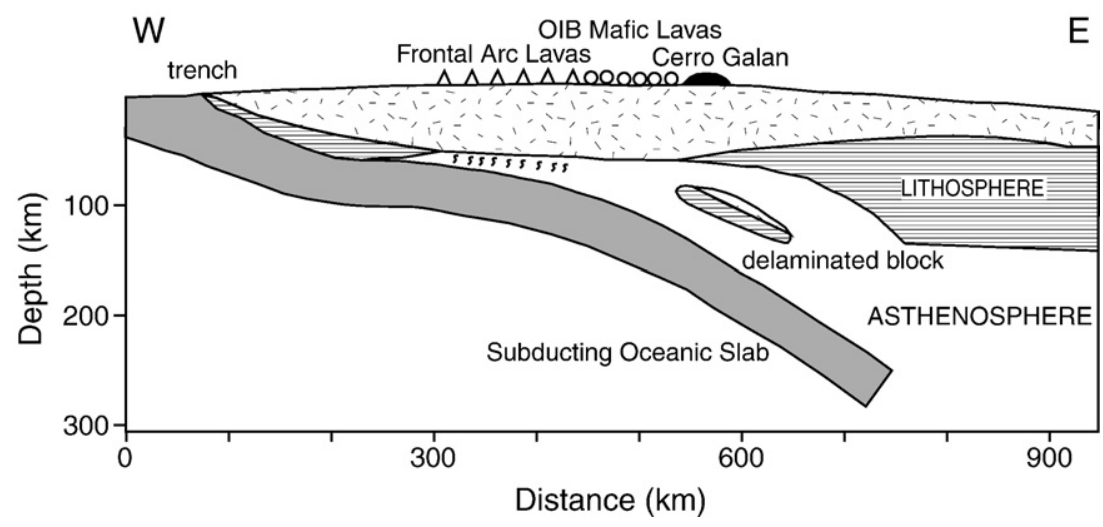

Fig. 13. Cartoon of the tectonic setting at $26^{\circ} \mathrm{S}$ in the Andean Arc showing the delamination of arc mantle and lower crust and associated mafic volcanism. Redrawn from Kay et al. (1994).

\section{Large igneous provinces}

In considering how crust is generated to replace the losses quantified above we focus on magmatic production in subduction settings and in LIPs because normal mid ocean ridge crust is efficiently recycled back to the mantle in subduction zones. In this section we assess the possible volumetric contribution of the LIPs to crustal construction since the Permian ( 250 Ma).

\subsection{Oceanic LIPS}

Magmatism related to hotspot activity has been suggested to be a significant source of new continental crust. This suggestion is based on the idea that large oceanic igneous edifices resist subduction and are accreted to continental margins after they collide with an active plate margin. The type example of this type of crust is the OntongJava Plateau, which first collided with the Solomon arc, causing subduction polarity reversal (Cowley et al., 2004). It appears that Ontong-Java Plateau is not being subducted. Although it is not yet in collision with a continental mass the plateau's location along an active margin places it in a position where it could be accreted once the oceanic basin finally closes. Clearly we do not know how much of the original crustal volume would be finally preserved in a continent there is no evidence of significant crust loss from the plateau at this time. The igneous crust of the Ontong Java Plateau may be transformed into a composition more representative of average continental crust under the influence of deformation and magmatism (Stein and Goldstein, 1996; Kusky and Polat, 1999; Hollister and Andronicos, 2006). The plateau's stability appears to be caused by its thick crust (20-35 km), but particularly by the unusually deep lithospheric roots, which extend to ca. $300 \mathrm{~km}$ (Klosko et al., 2001) and which were formed soon after the rapid emplacement (Tarduno et al., 1991). Rapid melt extraction is expected to form a buoyant and more viscous mantle peridotite root that may cause long-lived lithospheric strength (Phipps Morgan et al., 1995).
Ontong-Java is however, somewhat unusual in being easily the largest oceanic LIP on Earth. The seamount chains formed by more steady state hotspot activity are much smaller and mostly subducted. Where these collide with tectonically erosive active margins there is some evidence to suggest a temporary accretion of a modest part the seamount into the outer forearc (Johnson et al., 1991), although this is then typically removed by tectonic erosion with time (Vannucchi et al., 2006). Even in accretionary plate margins volcanic seamounts are generally subducted, with only thin slices of basalts ( $<1 \mathrm{~km}$ thick) being offscraped into the wedge of trench sediment (Taira et al., 1988; Collot et al., 1994; Kusky et al., 1997). We conclude that hotspot magmatism that is not erupted in a major plateau has little chance of being preserved in the continental crust.

In order to assess the potential contribution from oceanic plateaus to continental crust growth we consider a number of the largest examples (Fig. 1) whose volumes have already been estimated by gravity and seismic geophysical methods (Fig. 14). These range in size from the Ontong Java Plateau at $44.4 \times 10^{6} \mathrm{~km}^{3}$ (Coffin and Eldholm, 1994 ) to the Wallaby Plateau offshore SW Australia at $4.2 \times 10^{6} \mathrm{~km}^{3}$ (Schubert and Sandwell, 1989). For the most part we use the crustal volumes of Schubert and Sandwell (1989), but with updated values from Sager et al. (1999) for the Shatksy Rise, from Coffin et al. (2002) for the Kerguelen Plateau and from Coffin and Eldholm (1994) for Ontong Java. Adding together the crustal volumes in these plateaus results in a total of $152 \times 10^{6} \mathrm{~km}^{3}$. The oldest plateau considered is Magellan Rise, located in the northern central Pacific Ocean, whose emplacement is dated at ca. 135-140 Ma (Winterer et al., 1973; Larson, 1976). Dividing the total volume by 140 Ma results in a longterm plateau production rate of $1.1 \mathrm{~km}^{3} / \mathrm{a}$.

\subsection{Continental flood basalts}

Hotspot magmatism that is added directly to the continental crust is much easier to understand as a potential contributor to net crustal volumes. Here we estimate the potential long-term contributions from the nine largest continental flood basalt provinces, whose

Table 6

Estimates of crustal loss as a result of lower crustal delamination in continental regions outside active volcanic arcs, where lower crustal delamination is a continuous process.

\begin{tabular}{|c|c|c|c|c|c|}
\hline Province & $\begin{array}{l}\text { Area of delamination } \\
\left(\mathrm{km}^{2}\right)\end{array}$ & $\begin{array}{l}\text { Delaminated thickness } \\
(\mathrm{km})\end{array}$ & $\begin{array}{l}\text { Volume delaminated } \\
\left(\mathrm{km}^{3}\right)\end{array}$ & $\begin{array}{l}\text { Age of delamination } \\
\text { (Ma) }\end{array}$ & Reference \\
\hline North China craton & 600,000 & 7.5 & $4,500,000$ & $120 \mathrm{Ma}$ & Gao et al. $(1998,2004)$ \\
\hline Alboran Sea, Mediterranean Sea & 60,000 & 25 & $1,500,000$ & $21 \mathrm{Ma}$ & (Platt and Vissers, 1989; Platt et al., 2003) \\
\hline Andes, Puna Plateau & 430,000 & 15 & $6,450,000$ & $3 \mathrm{Ma}$ & Kay et al. (1994) \\
\hline Sierra Nevada, North America & 60,000 & 10 & 600,000 & $<10 \mathrm{Ma}$ & (Zandt et al., 2004; Ducea, 2002) \\
\hline Total & & & $13,050,000$ & & \\
\hline Global average rate $\left(\mathrm{km}^{3} / \mathrm{yr}\right.$.) & & & 1.1 & & \\
\hline
\end{tabular}




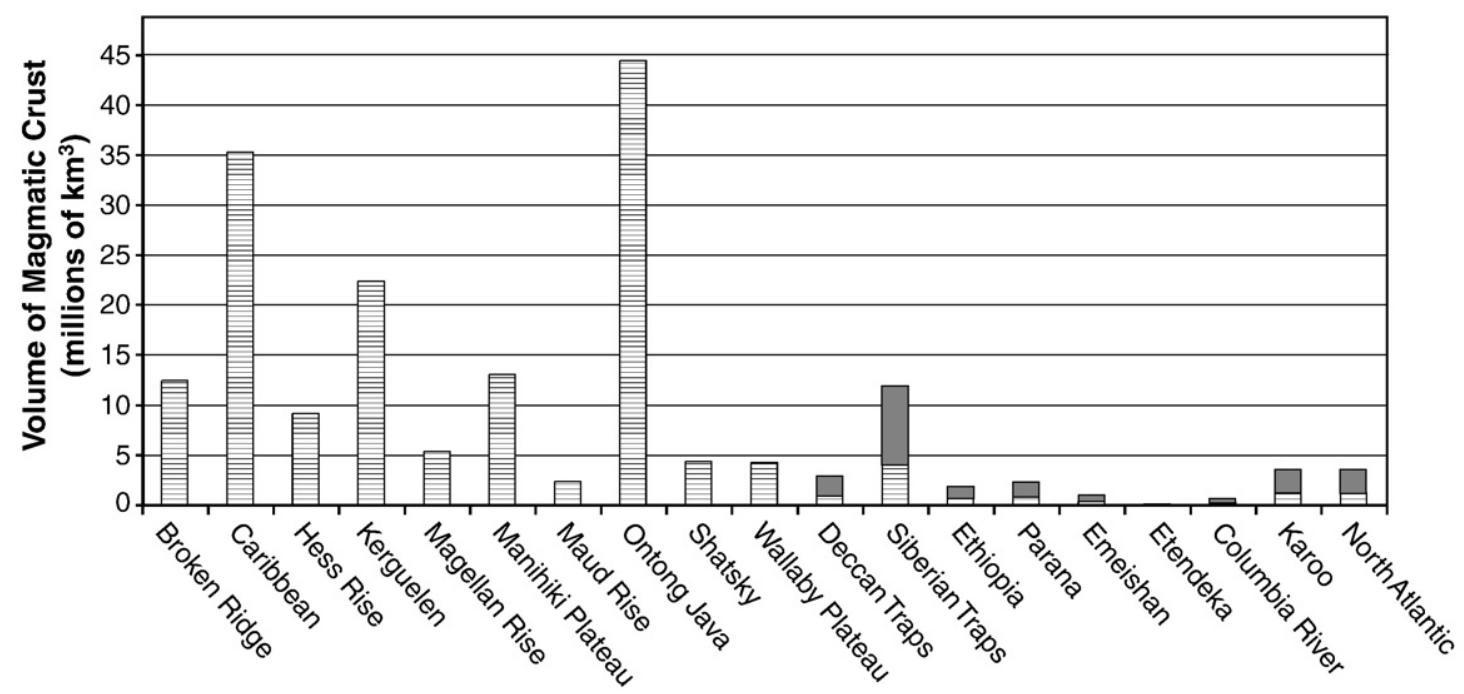

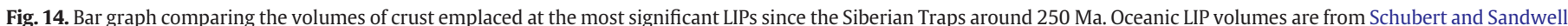

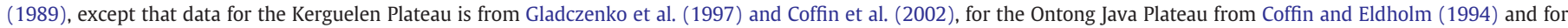

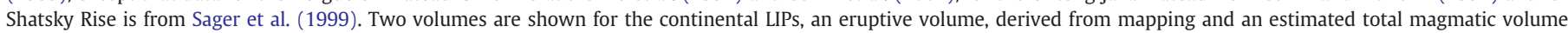
assuming that $75 \%$ of the true magma volume is emplaced within the underlying crust (White et al., 2008). Data for the continental LIPs is provided in Table 7.

general dimensions are provided in Table 7 (Fig. 1). In each case we have attempted to estimate the original, uneroded volume of volcanic rock by considering the original total aerial extent of the flood lavas. Where the literature suggests a relative uniform sheet-like geometry and provides a good estimate of the average thickness then the original emplaced volume can be readily determined. In other cases where there appears to be significant lateral change in lava thickness we estimate the original eruptive volume assuming a cone-like form thinning to zero around its edges and reaching a maximum in the center of the province. The modern preserved volume is in some cases significantly less than that originally emplaced because of subaerial erosion (Fig. 15).

Modern, preserved volumes can be estimated through quantification of the modern topography and knowledge of the thickness of the lava piles. In some cases very little of the LIP now remains. We estimate that only 6\% of the Permian Emeishan Province of China and $11 \%$ of the Jurassic Karoo Sequences of southern Africa are still preserved. Conversely, where continental LIPs are emplaced in marine sedimentary basins then much of the volcanic output is preserved because it is not exposed and eroded. Although the British Tertiary section of the North Atlantic LIP has experienced significant erosion in the western islands of Scotland, most of the volcanic rocks lie buried offshore in the Faeroe-Shetland and Rockall Trough basins (Boldreel and Andersen, 1998; White et al., 2003). Large volumes of lava still exist in East Greenland, even if the volume is hard to image because of the ice sheets. As a result we calculate that $95 \%$ of the original volume of this LIP $\left(\sim 1.0 \times 10^{6} \mathrm{~km}^{3}\right)$ is still preserved and forms part of the crust of NW Europe.

A difficulty that remains in estimating the total contribution to the crust is determining how much material is emplaced as intrusions within the crust, compared to the erupted volume, which is much easier to measure. Ample geophysical evidence exists for major magmatic underplating along the rifted edges of continents in rifted volcanic margins (White et al., 1987; Lizarralde and Holbrook, 1997; van Wijk et al., 2004). Further away from the continent-ocean transition regional basin inversion and permanent uplift testify to crustal thickening by magmatic additions (Brodie and White, 1994; Widdowson and Cox, 1996). However, this approach is only suitable in areas with good geophysical coverage and this is not universally available, especially in continental interiors, where there is also no

Table 7

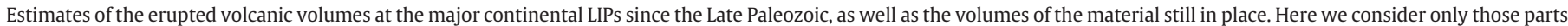

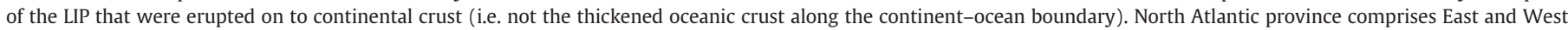
Greenland, the Faeroes, together with the British Isles, including the Faeroe-Shetland Basin and the Rockall Trough.

\begin{tabular}{|c|c|c|c|c|c|c|c|}
\hline & $\begin{array}{l}\text { Area of } \\
\text { original } \\
\text { emplacement } \\
\left(\mathrm{km}^{2}\right)\end{array}$ & $\begin{array}{l}\text { Maximum } \\
\text { thickness } \\
(\mathrm{km})\end{array}$ & $\begin{array}{l}\text { Original } \\
\text { volcanic } \\
\text { volume } \\
\left(\mathrm{km}^{3}\right)\end{array}$ & $\begin{array}{l}\text { Modern } \\
\text { volcanic } \\
\text { volume } \\
\left(\mathrm{km}^{3}\right)\end{array}$ & $\begin{array}{l}\text { Eroded } \\
\text { volume } \\
\left(\mathrm{km}^{3}\right)\end{array}$ & $\begin{array}{l}\text { Estimated total } \\
\text { volume with } \\
\text { intrusives } \\
\left(\mathrm{km}^{3}\right)\end{array}$ & Reference \\
\hline Deccan Traps & 920,000 & 1.7 & 739,243 & 485,908 & 253,335 & $2,956,972$ & Beane et al. (1986) \\
\hline Siberian Traps & $1,500,000$ & 3.5 & $3,050,000$ & $1,700,000$ & $1,350,000$ & $12,200,000$ & $\begin{array}{l}\text { (Fedorenko et al., 1996; Wignall, 2001; } \\
\text { Reichow et al., 2002) }\end{array}$ \\
\hline Ethiopia & $1,108,075$ & 1.6 & 590,973 & 350,000 & 240,973 & $2,363,892$ & (Baker et al., 1972; Mohr and Zanettin, 1988) \\
\hline Parana & $1,200,000$ & 1.7 & 680,000 & 322,062 & 357,938 & $2,720,000$ & Peate $(1997)$ \\
\hline Emeishan & 250,000 & 0.7 & 300,000 & 19,626 & 280,374 & $1,200,000$ & Ali et al. (2005) \\
\hline Etendeka & 80,000 & 0.45 & 36,000 & 6,046 & 29,954 & 144,000 & (Peate, 1997; Jerram et al., 1999) \\
\hline Columbia River & 160,438 & 3.5 & 187,178 & 175,000 & 12,178 & 748,712 & (Hooper, 1997; Tolan et al., 1989) \\
\hline Karoo & $2,060,939$ & 1.5 & $1,030,469$ & 116,391 & 914,078 & $4,121,877$ & Marsh et al. (1997) \\
\hline North Atlantic & 600,745 & 7.0 & $1,001,925$ & 935,935 & 65,990 & $4,007,699$ & $\begin{array}{l}\text { (Brown, 1963; Boldreel and Andersen, 1998; } \\
\text { Escher and Watts, 1976; Larsen et al., 1992; } \\
\text { Emeleus and Bell, 2005; Waagstein, 1988; } \\
\text { White et al., 2003) }\end{array}$ \\
\hline Total & & & $7,615,788$ & $4,110,967$ & $3,504,821$ & $30,463,152$ & \\
\hline
\end{tabular}




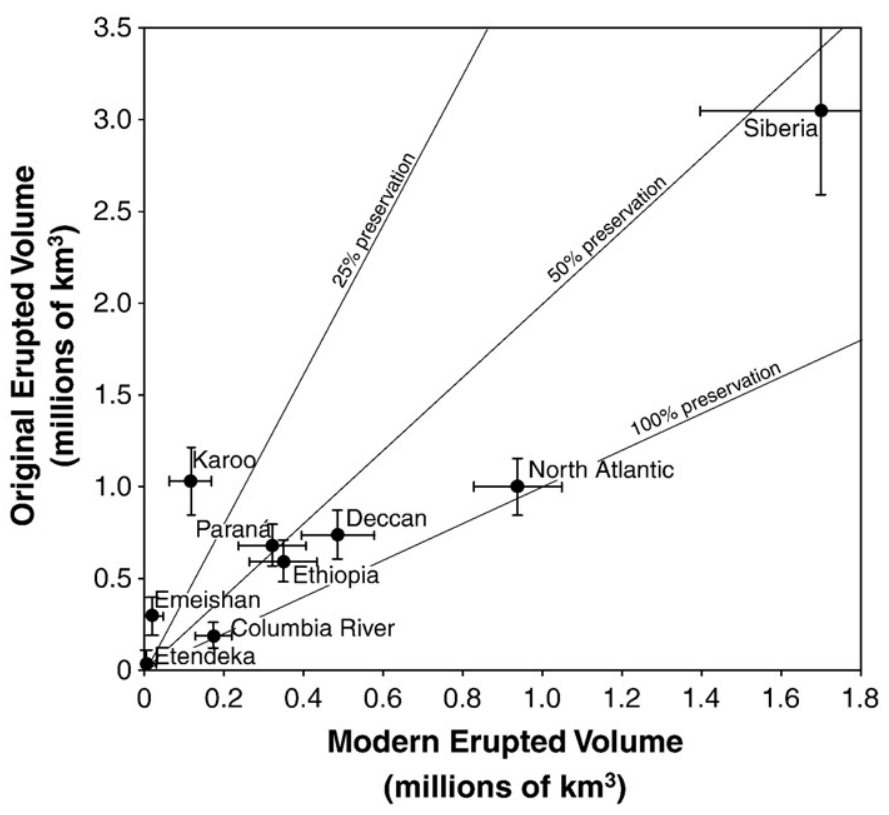

Fig. 15. Diagram showing the volumes of erupted and preserved material observed and reconstructed in the major continental LIPs (Flood Basalt Provinces).

preserved sedimentary record of vertical motions. Instead we here refer to the compilation of White et al. (2008), who examined a range of igneous provinces estimating the ratios of extrusive versus intrusive products. Although ratios ranged wildly in some of the small examples, many of the extrusive: intrusive ratios lie in the range $1: 2$ to $1: 5$. In this study we therefore take a value of $1: 3$ as a rough guide to the volume of intrusive rocks potentially underplating the continental crust under each of the flood basalt provinces considered. Thus, while our compilation estimated a total volume of $7.6 \times 10^{6} \mathrm{~km}^{3}$ of volcanic rock, the total mass potentially emplaced into the crust is ca. $30 \times 10^{6} \mathrm{~km}^{3}$ after addition of the intruded mass. The oldest province considered is also the largest, the Siberia Traps, estimated here at $12 \times 10^{6} \mathrm{~km}^{3}$. Because this was emplaced at the PermianTriassic boundary (ca. $250 \mathrm{Ma}$ ) (Reichow et al., 2002) we average the net contribution to the crust by dividing the total by $250 \mathrm{Ma}$. This results in a long-term addition rate of $0.12 \mathrm{~km}^{3} / \mathrm{a}$ for all flood basalt provinces.

Fig. 14 shows how small the potential contribution from continental flood basalt provinces is compared to oceanic LIPs. Thus, even if we were to discover large volumes of offshore lavas associated with the Paraná or Deccan Traps, as we have in the North Atlantic, it seems unlikely that this would greatly change the volume of flood magmatic rocks. Indeed, our estimate does not account for the erosion of the volcanic sequences, much of which has been returned to the continental margins, where the sediment is in a subductable state (Fig. 15). We conclude that the continental LIPs have not been major builders of continental crust during the Phanerozoic and are around an order of magnitude less significant than the other processes discussed here (Table 8).

\section{Arc magmatism}

Although accretion of oceanic LIPs to the edges of cratons may account for around $1.1 \mathrm{~km}^{3} / \mathrm{a}$ of continental growth we estimate a total long-term crustal loss rate of around $4.9 \mathrm{~km}^{3} / \mathrm{a}$ when we combine all the potential sinks of crustal material discussed above. Continental LIPs are relatively small and accretionary plate margins only represent the redistribution of existing crust. As a result arc magmatism must average net production of around $3.8 \mathrm{~km}^{3} / \mathrm{a}$ of andesitic crust if the volume of the crust is to be maintained over long periods of time (Fig. 16). This prediction is consistent with tectonic and geochemical evidence indicating that active margins are likely the principle source of the continental crust (Dewey and Windley, 1981; Rudnick and Fountain, 1995; Taylor and McLennan, 1995; Barth et al., 2000).

Clift and Vannucchi (2004) estimated a mean magma production rates of $90 \mathrm{~km}^{3} / \mathrm{Ma} / \mathrm{km}$ of trench based on their mass recycling rates, which did not factor in any major crustal losses outside steady state subduction. This is equivalent to $3.6 \mathrm{~km}^{3} / \mathrm{a}$, slightly less than that required to balance the crustal volume, which we estimate at $3.8 \mathrm{~km}^{3} / \mathrm{a}$.

A long-term rate of arc production of $3.8 \mathrm{~km}^{3} /$ a would imply a mean net magmatic production rate of $94 \mathrm{~km}^{3} / \mathrm{Ma} / \mathrm{km}$ for the global arc system. This figure does not include melt added to the crust and then delaminated as dense cumulates. This production rate represents the average long-term addition of andesitic (i.e. continental composition) crust, of which $20 \%$ could be mafic if chemical weathering was responsible for making the continental crust more silicic (Lee et al., 2008). This net crustal addition via arcs could occur in pulses of enhanced mafic accretion and associated intracrustal differentiation, which are associated with subduction initiation and arc-extension events. Steady state magmatism between these episodes appears to be much less productive. Evidence from the Marianas Arc shows that much its foundations are Eocene and date from the start of subduction (Bloomer et al., 1995), while the arc has been split twice since $45 \mathrm{Ma}$ to form backarc basins, during which times magmatic productivity greatly increased compared to the steady state condition (Taylor et al., 1991; Taylor, 1992). Similarly pulses in magmatism are also known from the Lau-Tonga arc system (Clift, 1995; Hawkins, 1995), and arc extension coupled with higher magmatism is presently probably occurring in Nicaragua (Phipps-Morgan et al., 2008). In order to generate crust close to continental compositions we envisage these magmatic pulses being followed by intracrustal segregation and delamination of ultramafic lower crustal residues.

Estimating true long-term production rates is hard because most of the magmatic output is not erupted but instead intruded into or underplated under the existing crust, where it is hard to image and quantify. In continental arcs it is impossible to resolve older from new magmatic additions in most circumstances and the volumes of lavas erupted are quite low (Atherton and Petford, 1996; White et al., 2008). Volcanic production rates represent a lower limit to the total production. Estimating long-term production rates is easier in oceanic systems because the entire crust is the product of supra-subduction zone magmatism. Only in a very few places is there evidence that the oceanic arc is built overlying pre-existing, normal, oceanic crust (Reuber, 1989). Most of the forearc crust in the Tonga, Mariana, Izu,

Table 8

Estimates of the average rates of crustal loss and production that are required to maintain the volume of the continental crust since the Permian. Arc production rates are derived from the difference between the losses and the rate of LIP accretion.

\begin{tabular}{ll}
\hline & $\begin{array}{l}\text { Mean rate } \\
\left(\mathrm{km}^{3} / \mathrm{yr}\right)\end{array}$ \\
\hline Negative fluxes & \\
Passive margins in collisions & 0.43 \\
Sediment subduction & 1.65 \\
Tectonic erosion & 1.35 \\
Continental delamination & 1.1 \\
Weathering & 0.4 \\
Total & 4.93 \\
& \\
Positive fluxes & \\
Arc magma & 3.8 \\
Oceanic plateaus & 1.1 \\
Continental LIPS & 0.03 \\
Total & 4.93 \\
Time to recycle entire crust (Ga) & 1.62 \\
\hline
\end{tabular}



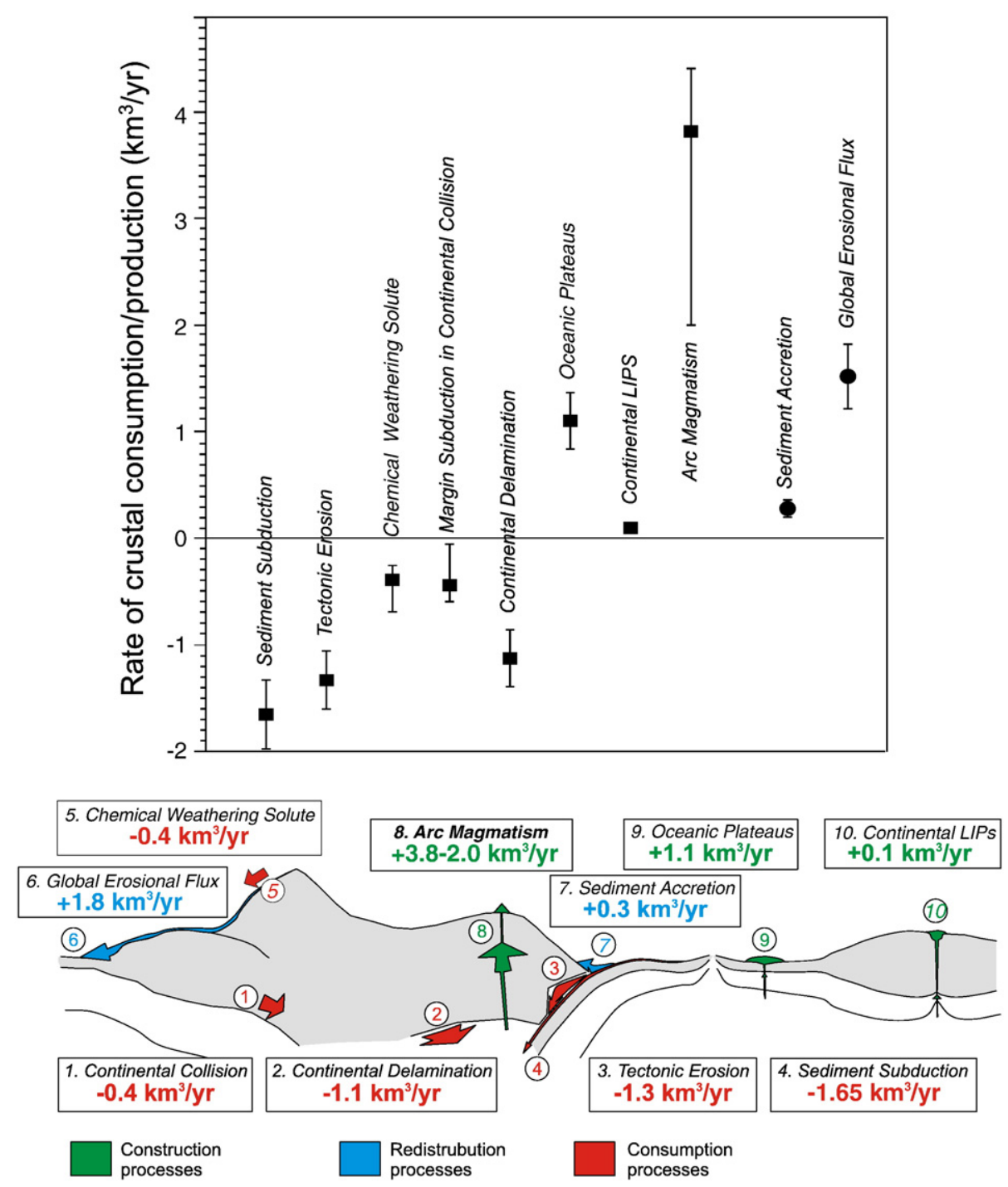

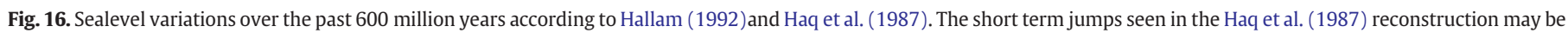
caused by glacial processes but the longer $10^{7}-10^{8}$ a cycles may be linked to variations in crustal volumes and/or crustal thicknesses.

and Bonin arcs on which the arcs are built is boninitic and was produced after the initiation of subduction, ca. $45 \mathrm{Ma}$ (Bloomer and Hawkins, 1987; Stern and Bloomer, 1992; Taylor and Goodliffe, 2004), meaning that it too is the product of subduction magmatism.

If the age of subduction initiation is known then an average rate of net melt production can be calculated. Holbrook et al. (1999) estimated long-term magmatic growth rates of $55-82 \mathrm{~km}^{3} / \mathrm{Ma} / \mathrm{km}$ for the Aleutians, while Suyehiro et al. (1996) indicated long-term average accretion rates of $66 \mathrm{~km}^{3} / \mathrm{Ma} / \mathrm{km}$ in the Izu Arc. However, a true magmatic production rate requires that these estimates account for the loss of crust by subduction erosion, because the present crustal volume divided by age only provides the net production rate, meaning that the true estimates of magmatic output for these arcs would be higher.

Clift and Vannucchi (2004) estimated forearc loss rates of 40 and close to $0 \mathrm{~km}^{3} / \mathrm{Ma} / \mathrm{km}$ respectively for the Izu and the Aleutians. This implies a long-term magma production rate of $106 \mathrm{~km}^{3} / \mathrm{Ma} / \mathrm{km}$ for the Izu-Bonin Arc and at least $82 \mathrm{~km}^{3} / \mathrm{Ma} / \mathrm{km}$ in the Aleutians. Although the Izu-Bonin rate is more than the global average of $94 \mathrm{~km}^{3} / \mathrm{Ma} / \mathrm{km}$ it should be recognized that this arc would be expected to be more productive than many because of its thin lithospheric lid that allows significant upwelling under the arc and thus more melting compared to a mature continental arc characterized by thick crust (Plank and Langmuir, 1988). Alternatively, if melting in arcs is controlled by the supply of aqueous fluids to the mantle wedge (Tatsumi et al., 1983; Stolper and Newman, 1994) then the rapid rate of convergence of $90 \mathrm{~mm} / \mathrm{a}$ in the Izu-Bonin (DeMets et al., 1990) would deliver more fluid and so favor higher than normal rates of magma production. Convergence rates of $75 \mathrm{~mm} / \mathrm{a}$ in the Aleutians are relatively average, consistent with the average magmatic productivity. We conclude that measured rates of arc magmatism are broadly in accord, if a little lower with those predicted to be needed to maintain the volumes of the continental crust.

\section{Discussion and conclusions}

Although there is some latitude for arc melt production rates to vary, the approximate correspondence between measured magmatic rates and those required to match the loss of crust in subduction zones would seem to argue that losses caused by poorly constrained processes such as lower crustal delamination cannot be much greater than we estimate here. If we had greatly underestimated the importance of lower crustal delamination, or the flux of dissolved crust from the continents in rivers then this would either mean a steadily decreasing crustal volume or the rate of arc production would have to be increased unrealistically high levels. Of the estimated losses the rate of subduction of trench sediment is best defined, while rates 
of subduction tectonic erosion and delamination are less well constrained. Our average arc melting rate of $3.8 \mathrm{~km}^{3} / \mathrm{a}$ assumes that oceanic plateau accretion is occurring at ca. $1.1 \mathrm{~km}^{3} / \mathrm{a}$. However, geologic evidence for accreted oceanic plateaus is not abundant, albeit with notably exceptions such as the Wrangellia Terrance of NW North America (Plafker et al., 1989). If the process of plateau accretion were less efficient then the rate of arc magmatism would again have to be higher to balance the documented losses. If arc output were much higher then it would be hard to reconcile with the geophysical evidence for subduction magmatic production. As it is the values predicted are on the high side of what is tenable. Our synthesis suggests that crustal delamination and subduction tectonic erosion are unlikely to be much higher than our estimates of $1.1 \mathrm{~km}^{3} / \mathrm{a}$ and $1.3 \mathrm{~km}^{3} /$ a respectively, especially if oceanic plateau accretion is less than perfectly efficient.

This review of the evolution of the continental crust shows that, at least since the Cretaceous, rates of continental crustal reworking have been quite high. Total losses average $4.9 \mathrm{~km}^{3} / \mathrm{a}$, based on rates of $0.4 \mathrm{~km}^{3} / \mathrm{a}$ of passive margin subduction in continental collision zones, $0.4 \mathrm{~km}^{3} / \mathrm{a}$ of dissolved chemical weathering flux, $1.1 \mathrm{~km}^{3} / \mathrm{a}$ of lower crustal delamination, $1.3 \mathrm{~km}^{3} / \mathrm{a}$ of forearc tectonic erosion and $1.7 \mathrm{~km}^{3} / \mathrm{a}$ of sediment subduction. At these rates the entire continental crust could be recycled into the mantle in $1.8 \mathrm{Ga}$. Clearly this has not happened because the centers of cratons have been stable and not recycled, while crust in active margins and orogens are susceptible to destruction by tectonic erosion, as well as by erosion by surface processes and subduction as sediment (Hawkesworth et al., 2009).

Estimating the rates of each of the processes we synthesize here is difficult and errors are necessarily large (Fig. 16). Demonstrating periods of long-term net crustal loss or growth since $250 \mathrm{Ma}$ is hard to do with current geologic data sets. Nonetheless, we show here that within the errors there may be an approximate balance between crustal losses and gains. Although the processes reworking crust appear to be quite active arc output approaches the levels required for there to be an overall stability to the system.

In this and many other works the freeboard argument has been used to argue for generally stable volumes of continental crust and oceanic water, and to a first order this is likely to be true. However, it is noteworthy that reconstructions of Phanerozoic sealevel show variations of $250-400 \mathrm{~m}$, depending on which model is preferred (Fig. 17) (Haq et al., 1987; Hallam, 1992). Clearly short-term variations in sealevel are driven by orbital processes acting on ice volumes, but cycles spanning $10^{8}$ a are not and have a tectonic origin. Changes in the mean depths of the ocean basins through time must have an impact on the global sealevel, with periods of continental collision associated with the destruction of old, ocean basins, followed by the rifting of younger, shallower oceans (Hays and Pitman, 1973; Pitman, 1978; Kominz, 1984). In addition, the compressional thickening of continental crust into mountain belts reduces the surface area of the Earth that is covered by continents, thus increasing ocean basin size (Whitehead and Clift, 2008). This process would lead to sea level falls, assuming a constant volume of water at the surface.

We note here that some of the recorded sealevel variation may be driven by changes in the total volume of continental crust. Low-stands of sealevel correlate with periods of intense orogeny: the modern Tibetan, Altiplano and Anatolian Plateaus during the Cenozoic, the Carboniferous Hercynian and Alleghenian Orogenies and the PanAfrican of the late Precambrian. As summarized above, orogeny is an opportunity for major crustal loss by: 1) passive margin subduction and slab break-off, 2) erosion of topography followed by sediment subduction and 3 ) the delamination of the lower crust in orogenic plateaus. Increased rates of crustal loss linked to major collisional episodes over the $10^{7}$ a timescales should be considered as one of the causes for long-term sealevel variation.

Considering only the Cenozoic the two sealevel curves show around 125-175 m of sealevel fall since $65 \mathrm{Ma}$ (Fig. 17). Recent studies

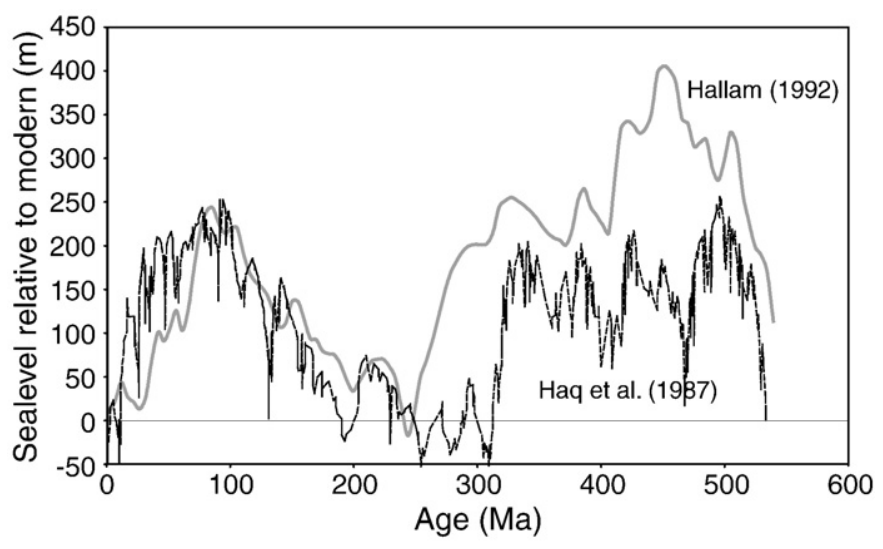

Fig. 17. Diagram showing the long-term time-integrated rates of mass flux in the Earth's crustal budget during the past 250 Ma.

suggest that the higher estimates are most consistent with the stratigraphic constraints (Müller et al., 2008). Together the Antarctic and Greenland ice sheets hold enough water to generate around $70 \mathrm{~m}$ of sealevel rise, meaning that $55-105 \mathrm{~m}$ of the observed sealevel fall has been driven by non-glacial processes. Of this ca. $64 \mathrm{~m}$ reflects the more compressed, orogenic character of crust in the modern Earth compared to $65 \mathrm{Ma}$ (Whitehead and Clift, 2009). After accounting for an increase in mean crustal thickness from 37.1 to $38.0 \mathrm{~km}$, we estimate that a long-term fall in sealevel of $55-105 \mathrm{~m}$ could be accomplished by a loss of continental crust at a rate of up to $1.8 \mathrm{~km}^{3} / \mathrm{a}$, although no loss would be required for the lower estimates of sealevel fall. At face value this suggests that arc production rates for the Cenozoic (and older times) could be as low as $2.0 \mathrm{~km}^{3} / \mathrm{a}$, with the system running a net crustal deficit since the Cretaceous. If the Cenozoic crustal inputs and outputs were out of balance by even half this amount then this might explain why the predicted rates of arc productivity needed to sustain a steady state crust during the Cenozoic exceed those measured from modern arc systems. A reduced longterm rate of $2.0 \mathrm{~km}^{3} / \mathrm{a}$ is equivalent to an average magma production of $50 \mathrm{~km}^{3} / \mathrm{Ma} / \mathrm{km}$.

A surprising conclusion of our synthesis is the degree to which continental material is recycled deep into the upper mantle and perhaps deeper via subduction zones and to a lesser extent in delaminating lower crustal material. Significant deep recycling is consistent with geophysical models for whole mantle convection (Kellogg et al., 1999; van der Hilst and Karason, 1999), as well as with geochemical evidence that subducted crust is important in the formation of mantle plume sources (White and Hoffman, 1982; Phipps Morgan and Morgan, 1999; Workman et al., 2008).

\section{Acknowledgements}

PC thanks the College of Physical Sciences, University of Aberdeen for assistance in conducting this study. PC wishes to thank Kevin Burke, Youngsook Huh, Amy Draut and Oliver Jagoutz for their advice during writing of this paper. The paper benefited from helpful reviews by Peter Cawood and Chris Hawkesworth.

\section{References}

Aal, A.A., Barkooky, A.E., Gerrits, M., Meyer, H.-J., Schwander, M., Zaki, H., 2001. Tectonic evolution of the Eastern Mediterranean basin and its significance for the hydrocarbon prospectivity of the Nile Delta deepwater area. GeoArabia 6 (3), 363-384.

Abele, C., Kenley, P.R., Holdgate, G., Ripper, D, 1976. Tertiary - Otway Basin. In: D. J.G., F. J.A. (Eds.), Geology of Victoria. Special Publication, vol. 5. Geological Society of Australia, pp. 198-229. 
Abreu, V., 1998. Geologic evolution of conjugate volcanic passive margins: Pelotas Basin (Brazil) and offshore Namibia (Africa); implication for global sea-level changes. Ph.D. Thesis, Rice University, Houston, TX, 648 pp.

Ahnert, F., 1970. Functional relationships between denudation, relief and uplift in large mid-latitude basins. Am. J. Sci. 268, 243-263.

Albarède, F., 1998. The growth of continental crust. Tectonophysics 296, 1-14.

Albarède, F., Brouxel, M., 1987. The Sm/Nd secular variation of the continental crust and the depleted mantle. Earth Planet. Sci. Lett. 82, 25-35.

Ali, J.R., Thompson, G.M., Meifu, Z., Xieyan, S., 2005. Emeishan large igneous province, SW China. Lithos 79 (3-4), 475-489.

Allegre, C., Dupré, B., Négrel, P., Gaillardet, J., 1996. Sr-Nd-Pb isotope systematics in Amazon and Congo River systems: constraints about erosion processes. Chem. Geol. 131, 93-112.

Armstrong, R.L., Harmon, R.S., 1981. Radiogenic isotopes: the case for crustal recycling on a near-steady-state no-continental-growth Earth. Philos. Trans. R. Soc. Lond., Series A 301 (1461), 443-472.

Armstrong, T.R., Tracy, R.J., Hames, W.E., 1992. Contrasting styles of Taconian, Eastern Acadian and Western Acadian metamorphism, central and western New England. J. Metamorph. Geol. 10, 415-426.

Atherton, M.P., Petford, N., 1996. Plutonism and the growth of Andean crust at 9 degrees S from 100 to 3 Ma. J. South Am. Earth Sci. 9, 1-9.

Augustsson, C., Bahlburg, H., 2003. Active or passive continental margin? Geochemical and $\mathrm{Nd}$ isotope constraints of metasediments in the backstop of a pre-Andean accretionary wedge in southernmost Chile ( $\left.46^{\circ} 30^{\prime \prime}-48^{\circ} 30^{\prime \prime} \mathrm{S}\right)$. In: McCann, T., Saintot, A. (Eds.), Tracing tectonic deformation using the sediment record. : Special Publication, vol. 208. Geological Society London, pp. 253-268.

Barth, M.G., McDonough, W.F., Rudnick, R.L., 2000. Tracking the budget of $\mathrm{Nb}$ and $\mathrm{Ta}$ in the continental crust. Chem. Geol. 165, 197-213.

Beane, J.E., Turner, C.A., Hooper, P.R., Subbarao, K.V., Walsh, J.N., 1986. Stratigraphy, composition and form of the Deccan Basalts, Western Ghats. India. Bull. Volcan. 48 (1), 61-83.

Behn, M., Kelemen, P., 2006. Stability of arc lower crust; insights from the Talkeetna Arc section, south central Alaska, and the seismic structure of modern arcs. J. Geophys. Res. 111 (B11). doi:10.1029/2006JB004327.

Behn, M.D., Hirth, G., Kelemen, P., 2007. Trench-parallel anisotropy produced by foundering of arc lower crust. Science 317, 108-111.

Behrmann, J.H., Lewis, S.D., Cande, S.C., et al., 1994. Tectonics and geology of spreading ridge subduction at the Chile Triple Junction - a synthesis of results from Leg-141 of the Ocean Drilling Program. Geol. Rundsch. 83 (4), 832-852.

Bloomer, S.H., Hawkins, J.W., 1987. Petrology and geochemistry of boninite series volcanic rocks from the Mariana trench. Contrib. Mineral. Petrol. 97, 361-377.

Bloomer, S.H., Taylor, B., MacLeod, C.J., Stern, R.J., Fryer, P., Johnson, L., 1995. Early arc volcanism and the ophiolite problem: a perspective from drilling in the Western Pacific. In: Taylor, B., Natland, J. (Eds.), Active Margins and Marginal Basins of the Western Pacific. Geophysical Monograph Series, vol. 88. American Geophysical Union, Washington D.C., pp. 67-96.

Blum, A.E., 1994. Feldspars in weathering. In: Parsons, I. (Ed.), Feldspars and their Reactions. NATO Advanced Study Institutes Series, Series C: Mathematical and Physical Sciences, vol. 421. Reidel Publishing Company, Dordrecht-Boston, pp. 595-630.

Boldreel, L.O., Andersen, M.S., 1998. Tertiary compressional structures on the FaroeRockall Plateau in relation to northeast Atlantic ridge-push and Alpine foreland stresses. Tectonophysics 300 (1-4), 13-28.

Booth-Rea, G., Ranero, C.R., Martinez-Martinez, J.M., Grevemeyer, I., 2007. Crustal types and Tertiary tectonic evolution of the Alboran Sea, western Mediterranean. Geochem. Geophys. Geosyst. 8 (Q10005). doi:10.1029/2007GC001639.

Brew, G.E., Litak, R.K., Seber, D., Barazangi, M., 1997. Summary of the geological evolution of Syria through geophysical interpretation: Implications for hydrocarbon exploration. The Leading Edge 16, 1473-1482.

Brodie, J., White, N., 1994. Sedimentary basin inversion caused by igneous underplating: Northwest European continental shelf. Geology 22, 147-150.

Brown, G.M., 1963. Melting relations of Tertiary granitic rocks in Skye and Rhum. Mineralogical Magazine 33, 533-562.

Brown, L.F., 1995. Sequence Stratigraphy in Offshore South African Divergent Basins. AAPG Studies in Geology, 41. American Association of Petroleum Geologists, Tulsa Oklahoma.

Brown, C.M., Stephenson, A.E., 1991. Geology of the Murray Basin, southeastern Australia Bulletin, 235. Bureau of Mineral Resources, Australian Government Publishing Service. 430 pp.

Brown, D., Puchkov, V., Alvarez-Marron, J., Bea, F., Perez-Estaun, A., 2006. Tectonic processes in the Southern and Middle Urals; an overview. In: Gee, D.G., Stephenson, R.A. (Eds.), European lithosphere dynamics. Memoirs, vol. 32. Geological Society, London, pp. 407-419.

Brunet, M.F., Korotaev, M.V., Ershov, A.V., Nikishin, A.M., 2003. The South Caspian Basin: a review of its evolution from subsidence modelling. Sed. Geol. 156, 119-148.

Burbank, D.W., Leland, J., Fielding, E., Anderson, R.S., Brozovic, N., Reid, M.R., Duncan, C., 1996. Bedrock incision, rock uplift, and threshold hillslopes in the northwestern Himalayas. Nature 379, 505-509.

Burke, K., 1996. The African Plate. S. Afr. J. Geol. 99 (4), 1-163.

Burke, K., Gunnell, Y., 2008. The African erosion surface: a continental-scale synthesis of geomorphology, tectonics, and environmental change over the past 180 million years. Memoir, vol. 201. Geological Society of America, Boulder, CO. 66 pp.

Cameron, K.L., Cameron, M., 1985. Rare earth element, 87Sr/86Sr, and 143Nd/144Nd compositions of Cenozoic orogenic dacites from Baja California, northwestern Mexico, and adjacent west Texas: evidence for the predominance of a subcrustal component. Contrib. Min. Petrol. 91 (1), 1-11.
Campbell, I.H., Reiners, P.W., Allen, C.M., Nicolescu, S., Upadhyay, R., 2005. He-Pb double dating of detrital zircons from the Ganges and Indus rivers; implication for quantifying sediment recycling and provenance studies. Earth Planet. Sci. Lett. 237 (3-4), 402-432.

Carena, S., Suppe, J., Kao, H., 2002. Active detachment of Taiwan illuminated by small earthquakes and its control of first-order topography. Geology 30, 935-938.

Carr, M.J., Feigenson, M.D., Bennett, E.A., 1990. Incompatible element and isotopic evidence for tectonic control of source mixing and melt extraction along the Central American arc. Contrib. Min. Petrol. 105, 369-380.

Castillo, P.R., 1996. Original and geodynamic implication of the Dupal isotopic anomaly in volcanic rocks from the Philippine island arcs. Geology 24 (3), 271-274

Cawood, P.A., Kröner, A., Pisarevsky, S., 2006. Precambrian plate tectonics: criteria and evidence. GSA Today 16 (7), 4-11.

Christensen, N.I., Mooney, W.D., 1995. Seismic velocity structure and composition of the continental crust; a global view. J. Geophys. Res. 100, 9761-9788.

Clift, P.D., 1995. Volcaniclastic sedimentation and volcanism during the rifting of western Pacific island backarc basins. In: Taylor, B., Natland, J. (Eds.), Active margins and marginal basins of the Western Pacific. : Geophysical Monograph, vol. 88. American Geophysical Union, Washington DC, pp. 67-96.

Clift, P.D., 2002. A brief history of the Indus River. In: Clift, P.D., Kroon, D., Gaedicke, C. Craig, J. (Eds.), The Tectonic and Climatic Evolution of the Arabian Sea Region. Geological Society, London, Special Publications, vol. 195, pp. 237-258.

Clift, P.D., 2006. Controls on the erosion of Cenozoic Asia and the flux of clastic sediment to the ocean. Earth Planet. Sci. Lett. 241 (3-4), 571-580.

Clift, P.D., Blusztajn, J.S., 2005. Reorganization of the western Himalayan river system after five million years ago. Nature 438 (7070), 1001-1003.

Clift, P.D., Hartley, A., 2007. Slow rates of subduction erosion along the Andean margin and reduced global crustal recycling. Geology 35, 503-506.

Clift, P., Vannucchi, P., 2004. Controls on tectonic accretion versus erosion in subduction zones; implications for the origin and recycling of the continental crust. Rev. Geophys. 42 (RG2001). doi:10.1029/2003RG000127.

Clift, P.D., Shimizu, N., Layne, G., Gaedicke, C., Schlüter, H.U., Clark, M., Amjad, S., 2001. Development of the Indus Fan and its significance for the erosional history of the western Himalaya and Karakoram. Geol. Soc. Am. Bull. 113, 1039-1051.

Clift, P.D., Layne, G.D., Blusztajn, J., 2004. Marine sedimentary evidence for monsoon strengthening, Tibetan uplift and drainage evolution in east Asia. In: Clift, P., Kuhnt, W., Wang, P., Hayes, D. (Eds.), Continent-ocean interactions in the East Asian marginal seas. Geophysical Monograph, vol. 149. American Geophysical Union, Washington, DC, pp. 255-282.

Clift, P.D., Schouten, H., Draut, A.E., 2003. A general model of arc-continent collision and subduction polarity reversal from Taiwan and the Irish Caledonides. In: Larter, R.D. Leat, P.T. (Eds.), Intra-oceanic Subduction Systems; Tectonic and Magmatic Processes. Special Publication, vol. 219. Geological Society, London, pp. 81-98.

Clift, P.D., Pavlis, T., DeBari, S.M., Draut, A.E., Rioux, M., Kelemen, P.B., 2005. Subduction erosion of the Jurassic Talkeetna-Bonanza Arc and the Mesozoic accretionary tectonics of western North America. Geology 33 (11), 881-884.

Clift, P.D., Lin, A.T.S., Carter, A., et al., 2008. Orogenic collapse in the Ilan Plain Basin of northern Taiwan. In: Draut, A.E., Clift, P.D., Scholl, D.W. (Eds.), Sedimentation in arc collisional settings. Special paper, vol. 436. Geological Society of America, Boulder, CO, pp. 257-278.

Clift, P.D., Schouten, H., Vannucchi, P., 2009. Arc-Continent Collisions, Subduction Mass Recycling and the Maintenance of the Continental Crust. In: Cawood, P., Kroener, A. (Eds.), Accretionary Orogens in Space and Time, 318. Geological Society, London, pp. 75-103.

Coffin, M.F., Eldholm, O., 1994. Large igneous provinces: crustal structure, dimensins and external consequences. Rev. Geophys. 32, 1-36.

Coffin, M.F., Pringle, M., Duncan, R.A., Gladczenko, T.P.,Storey, M., Müller, R.D., Gahagan, L.M. 2002. Kerguelen hotspot magma output since 130 Ma. J. Petrol. 43 (7), 1121-1139.

Collot, J.-Y., Greene, H.G., Fisher, M.A., Geist, E., 1994. Tectonic accretion and deformation of the accretionary wedge in the North d'Entrecasteaux Ridge-New Hebrides Island Arc collision zone: evidence from multichannel seismic reflection profiles and Leg 134 results. Proc. Ocean Drill. Program, Sci. Rpt. (134), 5-18.

Corfield, R.I., Watts, A.B., Searle, M.P., 2005. Subsidence history of the north Indian continental margin, Zanskar-Ladakh Himalaya, NW India. J. Geol. Soc. Lond. 162 135-146.

Cowley, S., Mann, P., Coffin, M.F., Shipley, T.H., 2004. Oligocene to Recent tectonic history of the central Solomon intra-arc basin as determined from marine seismic reflection data and compilation of onland geology. Tectonophysics 389 (3-4), 267-307.

Currie, C.A., Beaumont, C., Huismans, R.S., 2007. The fate of subducted sediments: a case for backarc intrusion and underplating. Geology 35 (12), 1111-1114.

DeBari, S.M., Coleman, R.G., 1989. Examination of the deep levels of an island arc: evidence from the Tonsina Ultramafic-Mafic assemblage, Tonsina, Alaska. J. Geophys. Res. 94, 4373-4391.

DeCelles, P.G., Gehrels, G.E., Quade, J., LaReau, B., Spurlin, M., 2000. Tectonic implications of U-Pb zircon ages of the Himalayan orogenic belt in Nepal. Science 288 (5465), 497-499.

DeMets, C., Gordon, R.G., Argus, D.F., Stein, S., 1990. Current plate motions. Geophys. J. Int. 101 (2), 425-478.

DePaolo, D.J., Wasserburg, G.J., 1976. Nd isotopic variations and petrogenetic models Geophys. Res. Lett. 3 (5), 249-252.

Dercourt, J., Ricou, L.E., Vrielynck, B., 1993. Atlas Tethys, Paleoenvironmental Maps. Gauthier-Villars, Paris. 307 pp.

de Sigoyer, J., Chavagnac, V., Blichert-Toft, J., et al., 2000. Dating the Indian continental subduction and collisional thickening in the Northwest Himalaya; multichronology of the Tso Morari eclogites. Geology 28 (6), 487-490. 
Dessert, C., Dupré, B., Francois, L.M., Schott, J., Gaillardet, J., Chakrapani, G., Bajpai, S., 2001 Erosion of Deccan Traps determined by river geochemistry: impact on the global climate and the 87Sr/86Sr ratio of seawater. Earth Planet. Sci. Lett. 188, 459-474.

Dessert, C., Dupré, B., Gaillardet, J., Francois, L.M., Allegre, C., 2003. Basalt weathering laws and the impact of basalt weathering on the global carbon cycle. Chem. Geol. 202, 257-273.

Dewey, J.F., Ryan, P.D., 1990. The Ordovician Evolution of the South Mayo Trough, western Ireland. Tectonics 9, 887-901.

Dewey, J.F., Windley, B.F., 1981. Growth and differentiation of the continental crust. Philos. Trans. R. Soc. Lond. Ser. A 301, 189-206.

Dracheva, S.S., Savostinc, L.A., Groshevd, V.G., Brunie, I.E., 1998. Structure and geology of the continental shelf of the Laptev Sea, Eastern Russian Arctic. Tectonophysics 298 (4), 357-393

Draut, A.E., Clift, P.D., 2001. Geochemical evolution of arc magmatism during arccontinent collision, South Mayo, Ireland. Geology 29 (6), 543-546.

Draut, A.E., Clift, P.D., Hannigan, R.E., Layne, G., Shimizu, N., 2002. A model for continental crust genesis by arc accretion; rare earth element evidence from the Irish Caledonides. Earth Planet. Sci. Lett. 203 (3-4), 861-877.

Ducea, M.N., 2002. Constraints on the bulk composition and root foundering rates of continental arcs: a California arc perspective. J. Geophys. Res. 107 (2304). doi:10.1029/2001JB000643.

Ducea, M., Saleeby, J.B., 1998. Crustal recycling beneath continental arcs; silica-rich glass inclusions in ultramafic xenoliths from the Sierra Nevada, California. Earth Planet. Sci. Lett. 156 (1-2), 101-116.

Dupont, J., Herzer, R.H., 1985. Effect of subduction of the Louisville Ridge on the structure and morphology of the Tonga Arc. In: Scholl, D.W., Vallier, T.L. (Eds.), Geology and offshore resources of Pacific Island Arcs-Tonga region, vol. 2. Circum Pacific Council for Energy and Resources, pp. 323-332.

Ebbing, J., 2004. The crustal structure of the Eastern Alps from a combination of 3D gravity modelling and isostatic investigations. Tectonophysics 380 (1-2), 89-104.

Elkins-Tanton, L.T., 2005. Continental magmatism caused by lithospheric delamination. In: Foulger, G.R., Natland, J.H., Presnall, D.C., Anderson, D.L. (Eds.), Plates, plumes, and paradigms. Special Paper, vol. 388. Geological Society of America, Boulder, CO, pp. 449-461.

Elliott, T., Plank, T., Zindler, A., White, W., Bourdon, B., 1997. Element transport from subducted slab to volcanic front at the Mariana Arc. J. Geophys. Res. 102, 14991-15019.

Emeleus, C.H., Bell, B.R., 2005. British Regional Geology: the Palaeogene Volcanic Districts of Scotland. British Geological Survey, Keyworth. 214 pp.

Emery, K.O., Uchupi, E., Bowin, C.O., Phillips, J., Simpson, S.W., 1975. Continental margin off western Africa: Cape St Francis (South Africa) to Walvis Ridge (South West Africa). Am. Assoc. Petrol. Geol. Bull. 59 (1), 3-59.

Escher, A., Watts, W.S., 1976. Geology of Greenland. Geological Survey of Greenland, Copenhagen. 630 pp.

Ewart, A., Hawkesworth, C.J., 1987. The Pleistocene-Recent Tonga-Kermadec Arc lavas; interpretation of new isotopic and rare earth data in terms of a depleted mantle source model. J. Petrol. 28, 495-530.

Fedorenko, A., Lightfoot, P.C., Naldrett, A.J., Czamanske, G.K., Hawkesworth, C.J., Wooden, J.L., Ebel, D.S., 1996. Petrogenesis of the Siberian flood-basalt sequence at Noril'sk. Int. Geol. Rev. 38, 99-135.

Forsyth, D.W., Yang, Y., 2005. Lithosphere delamination and small-scale convection beneath California imaged with high resolution Rayleigh wave tomography. Abstr. Programs - Geol. Soc. Am. 37 (7), 59.

Francis, P.W., Hammil, M., Kretzachmar, G., Thorpe, R.S., 1978. The Cerro Galan Caldera, Northwest Argentina and its tectonic setting. Nature 274, 749-775. doi:10.1038/274749a0.

Fyfe, W.S., 1978. The evolution of the Earth's crust: modern plate tectonics to ancient hot spot tectonics? Chem. Geol. 23, 89-114.

Galloway, W.E., Bebout, D.G., Fisher, W.L., Dunlap Jr., J.B., Cabrera-Castro, R., Scoot, T.M. 1991. Cenozoic. In: Salvador, A. (Ed.), The Gulf of Mexico Basin. The Geology of North America, J. Geological Society of America, Boulder, CO, pp. 245-324.

Gao, S., Ducea, M.N., Zhenmin, J., Saleeby, J.B., 1998. Lower crustal delamination and evolution of continental crust. Geol. J. China Univ. 4 (3), 241-249.

Gao, S., Rudnick, R.L., Yuan, H.-L., 2004. Recycling lower continental crust in the North China craton. Nature 432, 892-897.

Garzanti, E., Baud, A., Mascle, G., 1987. Sedimentary record of the northward flight of India and its collision with Eurasia (Ladakh Himalaya, India). Geodin. Acta 1 (4/5), 297-312.

Gastil, G., 1960. The distribution of mineral dates in space and time. Am. J. Sci. 258, 1-35.

Giosan, L., Clift, P.D., Blusztajn, J., Tabrez, A., Constantinescu, S., Filip, F., 2006. On the control of climate- and human-modulated fluvial sediment delivery on river delta development: the Indus. Eos, Trans., Am. Geophys. U. 87 (52), OS14A-04.

Gladczenko, T.P., Coffin, M.F., Eldholm, O., 1997. Crustal structure of the Ontong Java Plateau: modeling of new gravity and existing seismic data. J. Geophys. Res. 102 (B19), 22711-22729.

Glennie, K.W., Hughes Clarke, M.W., Boeuf, M.G.A., Pilaar, W.F.H., Reinhardt, B.M., 1990 The northern Oman Tethyan continental margin: stratigraphy, structure, concepts and controversies. In: Robertson, A.H.F., Searle, M.P., Ries, A.C. (Eds.), The Geology and Tectonics of the Oman Region. Special Publication, vol. 49. Geological Society of London, pp. 773-786.

Gnibidenko, H.S., Khvedchuk, I.I., 1982. The tectonics of the Okhotsk Sea. Mar. Geol. 50, 155-198.

Goodbred Jr., S.L., Kuehl, S.A., 2000. Enormous Ganges-Brahmaputra sediment discharge during strengthened early Holocene monsoon. Geology 28 (12) 1083-1086.

Goss, A.R., Kay, S.M., 2006. Steep REE patterns and enriched Pb isotopes in southern Central American arc magmas; evidence for forearc subduction erosion? Geochem. Geophys. Geosyst. 7 (5). doi:10.1029/2005GC00116.
Graham, J.R., 1981. Fluvial sedimentation in the Lower Carboniferous of Clew Bay, County Mayo, Ireland. Sediment. Geol. 30 (3), 195-211.

Greene, A.R., DeBari, S.M., Kelemen, P.B., Blusztajn, J., Clift, P.D., 2006. A detailed geochemical study of island arc crust; the Talkeetna Arc section, South-Central Alaska. J. Petrol. 47 (6), 1051-1093.

Gurria, E., Mezcua, J., 2000. Seismic tomography of the crust and lithospheric mantle in the Betic Cordillera and Alboran Sea. Tectonophysics 329 (1-4), 99-119.

Hallam, A., 1992. Phanerozoic Sea-level Changes. The Perspectives in Paleobiology and Earth History Series. Columbia University Press, New York, NY. 266 pp.

Hampel, A., Adam, J., Kukowski, N., 2004. Response of the tectonically erosive south Peruvian forearc to subduction of the Nazca Ridge: analysis of three-dimensional analogue experiments. Tectonics 23 (TC5003). doi:10.1029/2003TC001585.

Haq, B.U., Hardenbol, J., Vail, P.R., 1987. Chronology of fluctuating sea levels since the Triassic. Science 235, 1156-1167.

Harrison, C.G.A., 1994. Rates of continental erosion and mountain building. Geol. Rundsch. 83, 431-437.

Hauck, M.L., Nelson, K.D., Brown, L.D., Zhao, W., Ross, A.R., 1998. Crustal structure of the Himalayan orogen at $\sim 90$ o east longitude from Project INDEPTH deep reflection profiles. Tectonics $17,481-500$

Hawkesworth, C.J., Cawood, P., Kemp, T., Storey, C., Dhuime, B., 2009. Geochemistry: a matter of preservation. Science 323, 49-50.

Hawkins, J.W., 1995. The geology of the Lau Basin. In: Taylor, B. (Ed.), Backarc Basin: Tectonics and Magmatism. Plenum Press, New York, pp. 63-138.

Hays, J.D., Pitman, W.C., 1973. Lithospheric plate motion, sea level changes and climatic and ecological consequences. Nature 246, 18-22. doi:10.1038/246018a0.

Hildebrand, R.S., Bowring, S.A., 1999. Crustal recycling by slab failure. Geology 27, $11-14$.

Hinz, K., VonHuene, R., Ranero, C.R., et al., 1996. Tectonic structure of the convergent Pacific margin offshore Costa Rica from multichannel seismic reflection data. Tectonics 15 (1) 54-\&.

Hoernle, K., Bogaard, P.v.d., Werner, R., Lissinna, B., Hauff, F., Alvarado, G., GarbeSchonberg, D., 2002. Missing history (16-71 Ma) of the Galapagos hotspot: implications for the tectonic and biological evolution of the Americas. Geology 30, 795-798.

Holbrook, W.S., Lizarralde, D., McGeary, S., Bangs, N., Diebold, J., 1999. Structure and composition of the Aleutian island arc and implications for continental crustal growth. Geology 27, 31-34.

Hollister, L.S., Andronicos, C.L., 2006. Formation of new continental crust in Western British Columbia during transpression and transtension. Earth Planet. Sci. Lett. 249, 29-38. doi:10.1016/j.epsl.2006.06.042.

Hooper, P.R., 1997. The Columbia River Flood Basalt Province: Current Status. In: Mahoney, J.J., Coffin, M.F. (Eds.), Large Igneous Provinces: Continental, Oceanic and Planetary Flood Volcanism. Geophysical Monograph, vol. 100. American Geophysical Union, Washington DC, pp. 1-27.

Horton, B.K., DeCelles, P.G., 1997. The modern foreland basin system adjacent to the Central Andes. Geology 25 (10), 895-898.

Huang, C.Y., Yuan, P.B., Tsao, S.H., 2006. Temporal and spatial records of active arccontinent collision in Taiwan: a synthesis. Geol. Soc. Amer. Bull. 118, 274-288.

Huh, Y., Edmond, J.M., 1999. The fluvial geochemistry of the rivers of Eastern Siberia: III. Tributaries of the Lena and Anabardraining the basement terrain of the Siberian Craton and the trans-Baikal Highlands. Geochim. Cosmochim. Acta 63, 967-987.

Hurley, P.M., Rand, J.R., 1969. Pre-drift continental nuclei. Science 164, 1229-1242.

Iizumi, S., Imaoka, T., Kagami, H., 2000. Sr-Nd ratios of gabbroic and dioritic rocks in a Cretaceous-Paleogene granite terrain, Southwest Japan. The Island Arc 9, 113-127.

Jacobsen, S.B., 1988. Isotopic constraints on crustal growth and recycling. Earth Planet. Sci. Lett. 90, 315-329.

Jagoutz, O., Müntener, O., Ulmer, P., Pettke, T., Burg, J.-P., Dawood, H., Hussain, S., 2007. Petrology and mineral chemistry of lower crustal intrusions: the Chilas complex, Kohistan (NW Pakistan). J. Petrol. 48 (10), 1895-1953. doi:10.1093/petrology/egm044.

Jerram, D.A., Mountney, N.P., Holzforster, F., Stollhofen, H., 1999. Internal stratigraphic relationships in the Etendeka Group in the Huab Basin, NW Namibia: understanding the onset of flood volcanism. J. Geodyn. 28, 393-418.

Jicha, B.R., Singer, B.S., Brophy, J.G., et al., 2004. Variable impact of the subducted slab on Aleutian island arc magma sources; evidence from $\mathrm{Sr}, \mathrm{Nd}, \mathrm{Pb}$, and $\mathrm{Hf}$ isotopes and trace element abundances. J. Petrol. 45 (9), 1845-1875.

Johnson, L.E., Fryer, P., Taylor, B., et al., 1991. New evidence for crustal accretion in the outer Mariana forearc: cretaceous radiolarian cherts and MORB-like lavas. Geology 19, 811-814.

Jones, C.H., Farmer, G.L., Unruh, J., 2004. Tectonics of Pliocene removal of lithosphere of the Sierra Nevada, California. Geol. Soc. Amer. Bull. 116 (11-12), 1408-1422.

Jull, M., Kelemen, P.B., 2001. On the conditions for lower crustal convective instability. J. Geophys. Res. 106, 6423-6446.

Karig, D.E., Kay, R.W., 1981. Fate of sediments on the descending plate at convergent margins. Philos. Trans. R. Soc. Lond. Ser. A 301, 233-251.

Kay, S.M., Coira, B.L., 2008. Shallowing and steepening subduction zones, continental lithospheric loss and crustal flow under the central Andean Altiplano-Puna plateau. In: Kay, S.M., Ramos, V.A., Dickinson, W.R. (Eds.), Backbone of the Americas: shallow subduction, plateau uplift and ridge collision. Memoir. Geological Society of America, Boulder, CO.

Kay, R.W., Kay, S.M., 1993. Delamination and delamination magmatism. Tectonophysics $219(1-3), 177-189$

Kay, S.M., Coira, B., Viramonte, J., 1994. Young mafic back arc volcanic rocks as indicators of continental lithospheric delamination beneath the Argentine Puna Plateau, Central Andes. J. Geophys. Res. 99 (B12), 24,323-24,339.

Kay, S.M., Mpodozis, C., Coira, B., 1999. Neogene magmatism, tectonism, and mineral deposits of the Central Andes (22 degrees to 33 degrees S latitude). In: Skinner, B.J. 
(Ed.), Geology and Ore Deposits of the Central Andes. Special Publication, vol. 7. Society of Economic Geologists, pp. 27-59.

Kelemen, P.B., Hanghøj, K., Greene, A.R., 2003. One view of the geochemistry of subduction-related magmatic arcs with an emphasis on primitive andesite and lower crust. In: Rudnick, R.L. (Ed.), The crust. Treatise on Geochemistry, vol. 3. Elsevier-Pergamon, Oxford, pp. 593-659.

Kellogg, L.H., Hager, B.H., Van der Hilst, R.D., 1999. Compositional stratification in the deep mantle. Science 283, 1881-1884.

Kemp, A.I.S., Hawkesworth, C.J., Paterson, B.A., Kinny, P.D., 2006. Episodic growth of the Gondwana supercontinent from hafnium and oxygen isotopes in zircon. Nature $439,580-583$.

Kepezhinskas, P., McDermott, F., Defant, M.J., et al., 1997. Trace element and Sr-Nd-Pb isotopic constraints on a three-component model of Kamchatka Arc petrogenesis. Geochim. Cosmochim. Acta 61 (3), 577-600. doi:10.1016/S0016-7037(96)00349-3.

Khan, M.A., Stern, R.J., Gribble, R.F., Windley, B.F., 1997. Geochemical and isotopic constraints on subduction polarity, magma sources, and palaeogeography of the Kohistan intraoceanic arc, northern Pakistan Himalaya. J. Geol. Soc. Lond. 154, 935-946.

Klosko, E.R., Russo, R.M., Okal, E.A., Richardson, W.P., 2001. Evidence for a rheologically strong chemical mantle root beneath the Ontong-Java Plateau. Earth Planet. Sci. Lett. $186(3-4), 347-361$.

Kominz, M.A., 1984. Oceanic ridge volumes and sea level change - an error analysis. In: Schlee, J. (Ed.), Interregional Unconformities and Hydrocarbon Accumulation. Memoir, vol. 36. American Association of Petroleum Geology, Tulsa, OK, pp. 109-127.

Kramers, J.D., Tolstikhin, I.N., 1997. Two major terrestrial Pb isotope paradoxes, forward transport modelling, core formation and the history of the continental crust. Chem. Geol. 139, 75-110.

Kuhlemann, J., Frisch, W., Dunkl, I., Szekely, B., 2001. Quantifying tectonic versus erosive denudation by the sediment budget: the Miocene core complexes of the Alps. Tectonophysics 330, 1-23.

Kusky, T.M., Polat, A., 1999. Growth of granite-greenstone terranes at convergent margins, and stabilization of Archean cratons. Tectonophysics 305 (1-3), 43-73.

Kusky, T.M., Bradley, D.C., Haeussler, P.J., Karl, S.M., 1997. Controls on accretion of flysch and melange belts at convergent margins; evidence from the Chugach Bay thrust and Iceworm Melange, Chugach accretionary wedge, Alaska. Tectonics 16, 855-878.

Larsen, L.M., Pedersen, A.K., Pedersen, G.K., Piasecki, S., 1992. Timing and duration of Early Tertiary volcanism in the North Atlantic: new evidence from West Greenland. In: Storey, B.C., Alabaster, T., Pankhurst, R.J. (Eds.), Magmatism and the Causes of Continental Break-up: Geological Society, London, Special Publication, vol. 68, pp. 321-333.

Larson, R.L., 1976. Late Jurassic and Early Cretaceous evolution of the western central Pacific Ocean. J. Geomagn. Geoelectr. 28, 219-236.

Laursen, J., Scholl, D.W., von Huene, R., 2002. Neotectonic deformation of the central Chile margin: deepwater forearc basin formation in response to hot spot ridge and seamount subduction. Tectonics 21 (1038(5). doi:10.1029/2001TC901023.

Lavier, L.L., Steckler, M.S., Brigaud, F., 2001. Climatic and tectonic controls on the Cenozoic evolution of the West African margin. Mar. Geol. 178, 63-80.

Lee, C.-T.A., Morton, D.M., Little, M.G., Kistler, R., Horodyskyj, U.N., Leeman, W.P., Agranier, A., 2008. Regulating continent growth and composition by chemical weathering. Proc. Nat. Acad. Sci. 5 (13), 4981-4986. doi:10.1073/pnas.0711143105.

Leech, M., Stockli, D.F., 2000. The late exhumation history of the ultrahigh-pressure Maksyutov Complex, south Ural Mountains, from new apatite fission track data. Tectonics 19 (1), 153-167.

Lizarralde, D., Holbrook, W.S., 1997. U.S. mid-Atlantic margin structure and early thermal evolution. J. Geophys. Res. 102, 22,855-22,875.

Lonergan, L., White, N., 1997. Origin of the Betic-Rif mountain belt. Tectonics 16 , 504-522.

Lucassen, F., Trumbull, R., Franz, G., Creixell, C., Vasquez, P., Romer, R., Figueroa, O., 2004. Distinguishing crustal recycling and juvenile additions at active continental margins: The Paleozoic to Recent compositional evolution of the Chilean Pacific margin (36-41 S). J. South Am. Earth Sci. 17, 103-119.

Macfarlane, A.M., 1993. Chronology of tectonic events in the crystalline core of the Himalaya, Langtang-National-Park, Central Nepal. Tectonics 12 (4), 1004-1025.

Mangino, S., Priestley, K., 1998. The crustal structure of the southern Caspian region. Geophys. J. Int. 133 (3), 630-648.

Marsh, J.S., Hooper, P.R., Rehacek, J., Duncan, R.A., Duncan, A.R., 1997. Stratigraphy and age of Karoo Basalts of Lesotho and implications for correlations within the Karoo Igneous Province. In: Mahoney, J.J., Coffin, M.F. (Eds.), Large Igneous Provinces: Continental, Oceanic and Planetary Flood Volcanism, 100. American Geophysical Union, Washington, DC, pp. 247-272.

Marquardt, C., Lavenu, A., Ortlieb, L., Godoya, E., Comte, D., 2004. Coastal neotectonics in southern Central Andes; uplift and deformation of marine terraces in northern Chile $\left(27^{\circ} \mathrm{S}\right)$. Tectonophysics $394,193-219$.

McDermott, F., Defant, M.J., Hawkesworth, C.J., Maury, R.C., Joron, J.L., 1993. Isotope and trace element evidence for three component mixing in the genesis of the North Luzon arc lavas (Philippines). Contrib. Min. Petrol. 113, 9-23.

McQuarrie, N., Horton, B.K., Zandt, G., Beck, S., DeCelles, P.G., 2005. Lithospheric evolution of the Andean fold-thrust belt, Bolivia, and the origin of the central Andean Plateau. Tectonophysics 399 (1-4), 15-37.

Menzies, M.A., Fan, W.-M., Zhang, M., 1993. Palaeozoic and Cenozoic lithoprobes and the loss of $>120 \mathrm{~km}$ of Archean lithosphere, Sino-Korean craton, China. In: Prichard, H.M., Alabaster, T., Harris, N.W., Neary, C.R. (Eds.), Magmatic Processes and Plate Tectonics, vol. 76. Geological Society, London, pp. 71-81.

Meredith, D.J., Egan, S.S., 2002. The geological and geodynamic evolution of the eastern Black Sea basin: insights from 2-D and 3-D tectonic modelling. Tectonophysics 350 (2), 157-179. doi:10.1016/S0040-1951(02)00121-X.
Métivier, F., Gaudemer, Y., Tapponnier, P.., Klein, M., 1999. Mass accumulation rates in Asia during the Cenozoic. Geophys. J. Int. 137 (2), 280-318.

Meybeck, M., 1976. Total mineral dissolved transport by world major rivers. Hydro. Sci. Bull. XXI (2), 265-284.

Milliman, J.D., 1997. Fluvial sediment discharge to the sea and the importance of regional tectonics. In: Ruddiman, W.F. (Ed.), Tectonic Uplift and Climate Change. Plenum Press, New York, pp. 239-257.

Mohr, P.. Zanettin, B., 1988. The Ethiopian Flood Basalt Province. In: Macdougall, J.D. (Ed.), Continental Flood Basalts. Kluwer Academic, Dordrecht, pp. 63-110.

Molnar, P., Houseman, G.A., 2004. The effects of buoyant crust on the gravitational instability of thickened mantle lithosphere at zones of intracontinental convergence. Geophys. J. Int. 158 (3), 1134-1150.

Moorbath, S., 1978. Age and isotope evidence for the evolution of the continental crust. Philos. Trans. R. Soc. Lond. Ser. A 288, 401-413.

Müller, R.D., Sdrolias, M. Gaina, C., Steinberger, B., Heine, C. 2008. Long-term sea-level fluctuations driven by ocean basin dynamics. Science 319 (5868), 1357-1362. doi:10.1126/science.1151540.

Nikishin, A.M., Korotaev, M.V., Ershov, A.V., Brunet, M.F., 2003. The Black Sea basin tectonic history and Neogene - Quaternary rapid subsidence modelling. Sed. Geol. $156,149-168$.

O'Nions, R.K., Evensen, N.M., Hamilton, P.J., 1979. Geochemical modelling of mantle differentiation and crustal growth. J. Geophys. Res. 84, 6091-6101.

Ortlieb, L., Zazo, C., Goy, J.L., Dabrio, C., Macharé, J., 1996. Pampa del Palo; an anomalous composite marine terrace on the uprising coast of southern Peru. J. South Am. Earth Sci. 9, 367-379.

Pamukcu, O.A., Akcig, Z., Demirbas, S., Zor, E., 2007. Investigation of Crustal Thickness in Eastern Anatolia Using Gravity. Magnetic and Topographic Data. Pure Appl. Geophys. 164 (11), 2345-2358. doi:10.1007/s00024-007-0267-7.

Parman, S.W., 2007. Helium isotopic evidence for episodic mantle melting and crustal growth. Nature 446, 900-903.

Parra, M., Faugeres, J.C., Grousset, F.E., Pujol, C., 1997. Sr-Nd isotopes as tracers of finegrained detrital sediments; the South-Barbados accretionary prism during the last 150 kyr. Mar. Geol. 136 (3-4), 225-243.

Parrish, R.R., Hodges, K.V., 1996. Isotopic constraints on the age and provenance of the Lesser and Greater Himalayan sequences, Nepalese Himalaya. Geol. Soc. Amer. Bull. 108 (7), 904-911.

Patchett, P.J., Ruiz, J., 1987. Nd isotopic ages of crust formation and metamorphism in the Precambrian of eastern and southern Mexico. Contrib. Mineral. Petrol. 96 (4), 523-528.

Patzkowsky, M.E., Smith, L.H., Markwick, P.J., Engberts, C.J., Gyllenhaal, E.D., 1991 Application of the Fujita-Ziegler paleoclimate model: Early Permian and Late Cretaceous examples. Palaeogeogr. Palaeoclimatol. Palaeoecol. 86, 67-85.

Pearce, J.A., Kempton, P.D., Nowell, G.M., Noble, S.R., 1999. Hf-Nd element and isotope perspective on the nature of provenance of mantle and subduction components in the western Pacific arc-basin systems. J. Petrol. 40, 1579-1611.

Pearson, D.G., Parman, S.W., Nowell, G.M., 2007. A link between large mantle melting events and continent growth seen in osmium isotopes. Nature 449, 202-205. doi:10.1038/nature06122.

Peate, D., 1997. The Parana-Etendeka Province. In: Mahoney, J.J., Coffin, M.F. (Eds.), Large Igneous Provinces: Continental, Oceanic and Planetary Flood Volcanism. Geophysical Monograph, vol. 100. American Geophysical Union, Washington, DC, pp. 217-245.

Phipps Morgan, J., Morgan, W.J., 1999. Two-stage melting and the geochemical evolution of the mantle; a recipe for mantle plum-pudding. Earth Planet. Sci. Lett. 170 (3), 215-239.

Phipps Morgan, J., Morgan, W.J., Price, E., 1995. Hotspot melting generates both hotspot melting and a hotspot swell.J. Geophys. Res. 100, 8045-8062. doi:10.1029/94JB02887.

Phipps-Morgan, J., Ranero, C.R., Vannucchi, P., 2008. Intra-arc extension in Central America: links between plate motions, tectonics, volcanism, and geochemistry. Earth Planet. Sci. Lett. 272 (1-2), 365-371.

Pinet, P., Souriau, M., 1988. Continental erosion and large-scale relief. Tectonics 7. 563-582.

Piper, D.J.W., Normark, W.R., 2001. Sandy Fans - from Amazon to Hueneme and Beyond Am. Assoc. Petrol. Geol. 85 (8), 1407-1438.

Pitman III, W.C., 1978. Relationship between eustasy and stratigraphic sequences of passive margins. Geol. Soc. Amer. Bull. 89, 1389-1403.

Plafker, G., Nokleberg, W.J., Lull, J.S., 1989. Bedrock geology and tectonic evolution of the Wrangellia, Peninsular, and Chugach terranes along the Trans-Alaska Crusta Transect in the northern Chugach Mountains and southern Copper River basin, Alaska. J. Geophys. Res. 94, 4255-4295.

Plank, T., Langmuir, C.H., 1988. An evaluation of the global variations in the major element chemistry of arc basalts. Earth Planet. Sci. Lett. 90, 349-370

Plank, T., Langmuir, C.H., 1993. Tracing trace elements from sediment input into volcanic output at subduction zones. Nature 362, 739-742.

Plank, T., Langmuir, C.H., 1998. The geochemical composition of subducting sediment and its consequences for the crust and mantle. Chem. Geol. 145, 325-394.

Platt, J.P., Vissers, R.L.M., 1989. Extensional collapse of thickened continental lithosphere: a working hypothesis for the Alboran Sea and Gibraltar Arc. Geology $17,540-543$.

Platt, J.P., Whitehouse, M.J., Kelley, S.P., Carter, A., Hollick, L., 2003. Simultaneous extensional exhumation across the Alboran Basin; implications for the causes of late orogenic extension. Geology 31 (3), 251-254.

Polat, A., Kerrich, R., 2002. Nd-isotope systematics of not very similar $2.7 \mathrm{Ga}$ adakites, magnesian andesites, and arc basalts, Superior Province: evidence for shallow crustal recycling at Archean subduction zones. Earth Planet. Sci. Lett. 202 (2), $345-360$. 
Rad, S., Louvat, P., Gorge, C., Gaillardet, J., Allègre, C.J., 2006. River dissolved and solid loads in the Lesser Antilles: New insight into basalt weathering processes. J. Geochem. Explor. 88 (1-3), 308-312.

Ratschbacher, L., Hacker, B.R., Webb, L.E., et al., 2000. Exhumation of the ultrahighpressure continental crust in east central China; Cretaceous and Cenozoic unroofing and the Tan-Lu Fault. J. Geophys. Res. 105 (B6), 13,303-13,338.

Reichow, M.K., Saunders, A.D., White, R.V., Pringle, M.S., Al'Mukhamedov, A.I. Medvedev, A.I., Kirda, N.P., 2002. 40Ar/39Ar dates from the West Siberian Basin: Siberian flood basalt province doubled. Science 296, 1846-1850. doi:10.1126/ science.1071671.

Reuber, I., 1989. The Dras arc: two successive volcanic events on eroded oceanic crust. Tectonophysics 161, 93-106.

Rodger, M., Watts, A.B., Greenroyd, C.J., Peirce, C., Hobbs, R.W., 2006. Evidence for unusually thin oceanic crust and strong mantle beneath the Amazon Fan. Geology 34 (12), 1081-1084.

Rudnick, R.L., Fountain, D.M., 1995. Nature and composition of the continental crust; lower crustal perspective. Rev. Geophys. 33 (267-309).

Sager, W.W., Kim, J., Klaus, A., Nakanishi, M., Khankishieva, L.M., 1999. Bathymetry of Shatsky Rise, Northwest Pacific Ocean: implications for ocean plateau development at a triple junction. J. Geophys. Res. 104, 7557-7576.

Sajona, F.G., Maury, R.C., Pubellier, M., Leterrier, J., Bellon, H., Cotten, J., 2000. Magmatic source enrichment by slab-derived melts in a young post-collision setting, central Mindanao (Philippines). Lithos 54, 173-206.

Scholl, D., von Huene, R., 2007. Crustal recycling at modern subduction zones applied to the past-Issues of growth and preservation of continental basement crust, mantle geochemistry, and supercontinent reconstruction. In: Hatcher, J.R.D. Carlson, M.P. McBride, J.H., Catalán, J.R.M. (Eds.), 4-D Framework of Continental Crust. : Memoir, vol. 200. Geological Society of America, Boulder, CO, pp. 9-32.

Schubert, G., Reymer, A.P.S., 1985. Continental volume and freeboard through geological time. Nature 316, 336-339.

Schubert, G., Sandwell, D., 1989. Crustal volumes of the continents and of oceanic and continental submarine plateaus. Earth Planet. Sci. Lett. 92, 234-246.

Schuth, S., Rohrbach, A., Münker, C., Ballhaus, C., Garbe-Schönberg, D., Qopoto, C., 2004 Geochemical constraints on the petrogenesis of arc picrites and basalts, New Georgia Group, Solomon Islands. Contrib. Min. Petrol. 148, 288-304. doi:10.1007/ s00410-004-0604-0.

Sclater, J.G., Christie, P.A.F., 1980. Continental stretching: an explanation of the post MidCretaceous subsidence of the central North Sea basin. J. Geophys. Res. 85, 3711-3739.

Shimoda, G., Tatsumi, Y., Nohda, S., Ishzaka, K., Jahn, B.M., 1998. Setouchi high-Mg andesites revisited: geochemical evidence for melting of subducting sediments. Earth Planet. Sci. Lett. 160 (3-4), 479-492.

Sinton, C.W., Duncan, R.A., Denyer, P., 1997. Nicoya Peninsula, Costa Rica: a single suite of Caribbean oceanic plateau magmas. J. Geophys. Res. 102, 15,507-15,520.

Smith, R.D., Cameron, K.L., McDowell, F.W., Niemeyer, S., Sampson, D.E., 1996 Generation of voluminous silicic magmas and formation of mid-Cenozoic crus beneath north-central Mexico: evidence from ignimbrites, associated lavas, deep crustal granulites, and mantle pyroxenites. Contrib. Mineral. Petrol. 123, 375-389.

Stancin, A.M., Gleason, J.D., Rea, D.K., Owen, R.M., Moore, T.C., Blum, J.D., Hovan, S.A. 2006. Radiogenic isotopic mapping of late Cenozoic eolian and hemipelagic sediment distribution in the east-central Pacific. Earth Planet. Sci. Lett. 248 (3-4) $840-850$

Stein, M., Goldstein, S.L., 1996. From plume head to continental lithosphere in the Arabian-Nubian shield. Nature 382, 773-778 doi:10.1038/382773a0.

Stern, R.J., 2005. Evidence from ophiolites, blueschists, and ultra-high pressure metamorphic terranes that the modern episode of subduction tectonics began in Neoproterozoic time. Geology 33, 557-560.

Stern, R.J., Bloomer, S.H., 1992. Subduction zone infancy: examples from the Eocene IzuBonin-Mariana and Jurassic California arcs. Geol. Soc. Amer. Bull. 104, 1621-1636

Stern, C.R., Kilian, R., 1996. Role of the subducted slab, mantle wedge and continenta crust in the generation of adakites from the Andean Austral Volcanic Zone. Contrib. Mineral. Petrol. 123, 263-281.

Stoakes, F.A., Campbell, C.V., Cass, R., Ucha, N., 1991. Seismic stratigraphic analysis of the Punta del Este Basin, offshore Uraguay. South America. Am. Assoc. Petrol. Geol. 75 (2), 219-240.

Stolper, E., Newman, S., 1994. The role of water in the petrogenesis of Mariana Trough magmas. Earth Planet. Sci. Lett. 121, 293-325.

Summerfield, M., Hulton, N.J., 1994. Natural controls of fluvial denudaiton rates in major world drainage basins. J. Geophys. Res. 99 (B7), 13871-13883.

Suppe, J., 1984. Kinematics of arc-continent collision, flipping of subduction, and backarc spreading near Taiwan. In: Tsan, S.F. (Ed.), A special volume dedicated to Chun-Sun Ho on the occasion of his retirement: Geological Society of Chin Memoir, vol. 6, pp. 21-33.

Suyehiro, K., Takahashi, N., Ariie, Y., et al., 1996. Continental crust, crustal underplating, and low-Q upper mantle beneath an oceanic island arc. Science 272, 390-392.

Swenson, J.L., Beck, S.L., Zandt, G., 2000. Crustal structure of the Altiplano from broadband regional waveform modeling: Implications for the composition of thick continental crust. J. Geophys. Res. 105 (B1), 607-622.

Taira, A., Katto, J., Tashiro, M., Okamura, M., Kodama, K., 1988. The Shimanto Belt in Shikoku, Japan; evolution of Cretaceous to Miocene accretionary prism. Mod. Geol. 12 (1-4), 5-46.

Takahashi, N., Kodaira, S., Klemperer, S., Tatsumi, Y., Kaneda, Y., Suyehiro, K., 2007. Structure and evolution of Izu-Ogasawara (Bonin)-Mariana oceanic island arc crust. Geology 35, 203-206.

Tarduno, J.A., Sliter, W.V., Kroenke, L., et al., 1991. Rapid formation of Ontong-Java plateau by Aptian mantle plume volcanism. Science 254, 399-403.
Tatsumi, Y., Sakuyama, M., Fukuyama, H., Kushiro, I., 1983. Generation of arc basalt magmas and thermal structure of the mantle wedge in subduction zones. J. Geophys. Res. 88, 5815-5825

Taylor, S.R., 1967. The origin and growth of continents. Tectonophysics 4, 17-34.

Taylor, B., 1992. Rifting and the volcanic-tectonic evolution of the Izu-Bonin-Mariana arc. Proc. Ocean Drill. Program, Sci. Rpt. 126, 627-651.

Taylor, B., Goodliffe, A.M., 2004. The west Philippine Basin and the initiation of subduction, revisited. Geophys. Res. Lett. 31. doi:10.1029/2004GL020136.

Taylor, S.R., McLennan, S.M., 1995. The geochemical evolution of the continental crust. Rev. Geophys. 33, 241-265

Taylor, B., Klaus, A., Brown, G.R., Moore, G.F., 1991. Structural development of Sumisu rift, Izu-Bonin Arc. J. Geophys. Res. 96, 16,113-16,129.

Teng, L.S., 1990. Geotectonic evolution of late Cenozoic arc-continent collision in Taiwan. Tectonophysics 183, 57-76.

Teng, L.S., Lee, C.-T., Tsai, Y.-B., Hsiao, L.-Y., 2000. Slab breakoff as a mechanism for flipping of subduction polarity in Taiwan. Geology 28, 155-158.

Tolan, T.L., Reidel, S.P., Beeson, M.H., Anderson, J.L., Fecht, K.R., Swanson, D.A., 1989. Revisions to the estimates of the aerial extent and volume of the Columbia River Basalt Group. In: Reidel, S.P., Hooper, P.R. (Eds.), Volcanism and Tectonism in the Columbia River Flood Basalt Province. Special Paper, vol. 239. Geological Society of America, Boulder, CO, pp. 1-20.

Tosiani, T., Loubet, M., Viers, J., et al., 2004. Major and trace elements in river-borne materials from the Cuyuni basin (southern Venezuela): evidence for organocolloidal control on the dissolved load and element redistribution between the suspended and dissolved load. Chem. Geol. 211 (3-4), 305-334.

Treloar, P.J., Petterson, M.G., Jan, M.Q., Sullivan, M.A., 1996. A re-evaluation of the stratigraphy and evolution of the Kohistan arc sequence, Pakistan Himalaya: implications for magmatic and tectonic arc-building processes. J. Geol. Soc. Lond. 153, 681-693.

Treloar, P.J., O'Brien, P.J., Parrish, R.R., Khan, M.A., 2003. Exhumation of early Tertiary, coesite-bearing eclogites from the Pakistan Himalaya. J. Geol. Soc. Lond. 160, 367-376.

Tuttle, M.L.W. Charpentier, R.R. Brownfield, M.E. 1999. The Niger Delta Petroleum System: Niger Delta Province, Nigeria, Cameroon, and Equatorial Guinea, Africa. Open File Report. US Geological Survey.

Van Balen, R.T., Lenkey, L., Horvath, F., Cloetingh, S., 1999. Two-dimensional modelling of stratigraphy and compaction-driven fluid flow in the Pannonian Basin. In: Durand, B., Jolivet, L., Horvath, F., Séranne, M. (Eds.), The Mediterranean Basins: Tertiary Extension within the Alpine Orogen: Geological Society, London, Special Publication, vol. 156, pp. 391-414.

van der Hilst, R.D., Karason, H., 1999. Compositional heterogeneity in the bottom $1000 \mathrm{~km}$ of Earth's mantle: towards a hybrid convection model. Science 283, 1885-1888.

Vanneste, L.E, Larter, R.D. 2002. Sediment subduction, subduction erosion and strain regime in the northern South Sandwich forearc. J. Geophys. Res. 107 (B7), 2149. doi:10.1029/2001JB000396

Vannucchi, P., Fisher, D.M., Bier, S., Gardner, T.W., 2006. From seamount accretion to tectonic erosion: Formation of Osa Melange and the effects of Cocos Ridge subduction in southern Costa Rica. Tectonics 25 (TC2004(4)). doi:10.1029/2005TC001855.

Vannucchi, P., Remitti, F., Bettelli, G., 2008. Geological record of fluid flow and seismogenesis along an erosive subducting plate boundary. Nature 451, 699-704. doi:10.1038/nature06486.

van Wijk, J.W., van der Meer, R., Cloetingh, S., 2004. Crustal thickening in an extensional regime: application to the mid-Norwegian Vøring margin. Tectonophysics 387, 217-228

von Huene, R., Ranero, C.R., 2003. Subduction erosion and basal friction along the sediment-starved convergent margin off Antofagasta, Chile. J. Geophys. Res. 108 (2079(B2)). doi:10.1029/2001JB001569.

von Huene, R., Scholl, D.W., 1991. Observations at convergent margins concerning sediment subduction, subduction erosion, and the growth of continental crust. Rev. Geophys. 29 (3), 279-316.

von Huene, R., Corvalan, J., Flueh, E.R., et al., 1997. Tectonic control of the subducting Juan Fernandez Ridge on the Andean margin near Valparaiso, Chile. Tectonics 16 (3), 474-488

von Huene, R., Ranero, C., Vannucchi, P., 2004. Generic model of subduction erosion. Geology 32, 913-916.

Vroon, P.Z., van Bergen, M.J., Klaver, G.J., White, W.M., 1995. Strontium, neodymium, and lead isotopic and trace-element signatures of the East Indonesian sediments: provenance and implication for Banda Arc magma genesis. Geochim. Cosmochim. Acta 59, 2573-2598.

Waagstein, R., 1988. Structure, composition and age of the Faeroe Basalt plateau, Early Tertiary Volcanism and the opening of the NE Atlantic. In: Morton, A.C., Parson, L.M. (Eds.), Early Tertiary Volcanism and the opening of the NE Atlantic: Geological Society, London, Special Publication, vol. 39, pp. 225-238.

Weldeab, S., Emeis, K.C., Hemleben, C., Vennemann, T.W., Schulz, H., 2002. Sr and Nd isotope composition of late Pleistocene sapropels and nonsapropelic sediments from the eastern Mediterranean Sea; implications for detrital influx and climatic conditions in the source areas. Geochim. Cosmochim. Acta 66 (20), 3585-3598.

White, W.M., Hoffman, A.W., 1982. Sr and Nd isotope geochemistry of oceanic basalts and mantle evolution. Nature 296, 821-825. doi:10.1038/296821a0.

White, R.S., Westbrook, G.K., Bowen, A.N., et al., 1987. Hatton Bank (northwest UK) continental margin structure. Geophys. J. R. Astro. Soc. 89, 265-272.

White, R.S., Smallwood, J.R., Fliedner, M.M., Boslaugh, B., Maresh, J., Fruehn, J., 2003. Imaging and regional distribution of basalt flows in the Faeroe-Shetland Basin. Geophys. Prospect. 51 (3), 215-231.

White, S.M., Crisp, J.A., Spera, F.J., 2008. Long-term volumetric eruption rates and magma budgets. Geochem. Geophys. Geosyst. 7 (Q03010). doi:10.1029/2005GC001002. 
Whitehead, J.A., Clift, P.D., 2008. Continent elevation, mountains, erosion and freeboard Eos, Trans., Am. Geophys. U. 89 (53) Fall Meeting Abstract T53B-1950.

Whitehead, J., Clift, P.D., 2009. Continent elevation, mountains, erosion and freeboard. J. Geophys. Res. 114, B05410. doi:10.1029/2008JB006176.

Widdowson, M., Cox, K.G., 1996. Uplift and erosional history of the Deccan Traps, India : evidence from laterites and drainage patterns of the Western Ghats and Konkan Coast. Earth Planet. Sci. Lett. 137, 57-69.

Wignall, P.B., 2001. Large igneous provinces and mass extinctions. Earth-Sci. Rev. 53, $1-33$.

Winterer, E.L., Ewing, J.I., Shipboard Scientific Party, 1973. Initial Reports of the Deep Sea Drilling Project, 17. U.S. Govt. Printing Office, Washington DC. 1-353 pp.

Witze, A., 2006. The start of the world as we know it. Nature 442, 128-131.

Woodhead, J.D., Fraser, D.G., 1985. Pb, Sr, and 10Be isotopic studies of volcanic rocks from the Northern Mariana Islands: implications for magma genesis and crustal recycling in the western Pacific. Geochim. Cosmochim. Acta 49, 1925-1930.
Workman, R.K., Eiler, J., Hart, S.R., Jackson, M.G., 2008. Oxygen isotopes in Samoan lavas: confirmation of continent recycling. Geology 36 (7), 551-554. doi:10.1130/ G24558A.1.

Wu, Y., Louden, K.E., Funck, T., Jackson, H.R., Dehler, S.A., 2006. Crustal structure of the central Nova Scotia margin off Eastern Canada. Geophys. J. Int. 166 (2), 878-906.

Wu, Y.-M., Chang, C.-H., Zhao, L., Shyu, J.B.H., Chen, Y.-G., Sieh, K., Avouac, J.-P., 2007 Seismic tomography of Taiwan; improved constraints from a dense network of strong motion stations. J. Geophys. Res. 112 (B08312). doi:10.1029/2007JB004983.

Zandt, G., Gilbert, H., Owens, T.J., Ducea, M., Saleeby, J., Jones, C.H., 2004. Active foundering of a continental arc root beneath the southern Sierra Nevada in California. Nature 431 (7004), 41-46.

Zhang, P., Molnar, P., Downs, W.R., 2001. Increased sedimentation rates and grain sizes 2-4 Myr ago due to the influence of climate change on erosion rates. Nature 410, 891-897.

Zhang, X., Sun, R., Teng, J., 2007. Study on crustal, lithospheric and asthenospheric thickness beneath the Qinghai-Tibet Plateau and its adjacent areas. China Sci. Bull. 52 (6), 797-804. doi:10.1007/s11434-007-0110-7. 